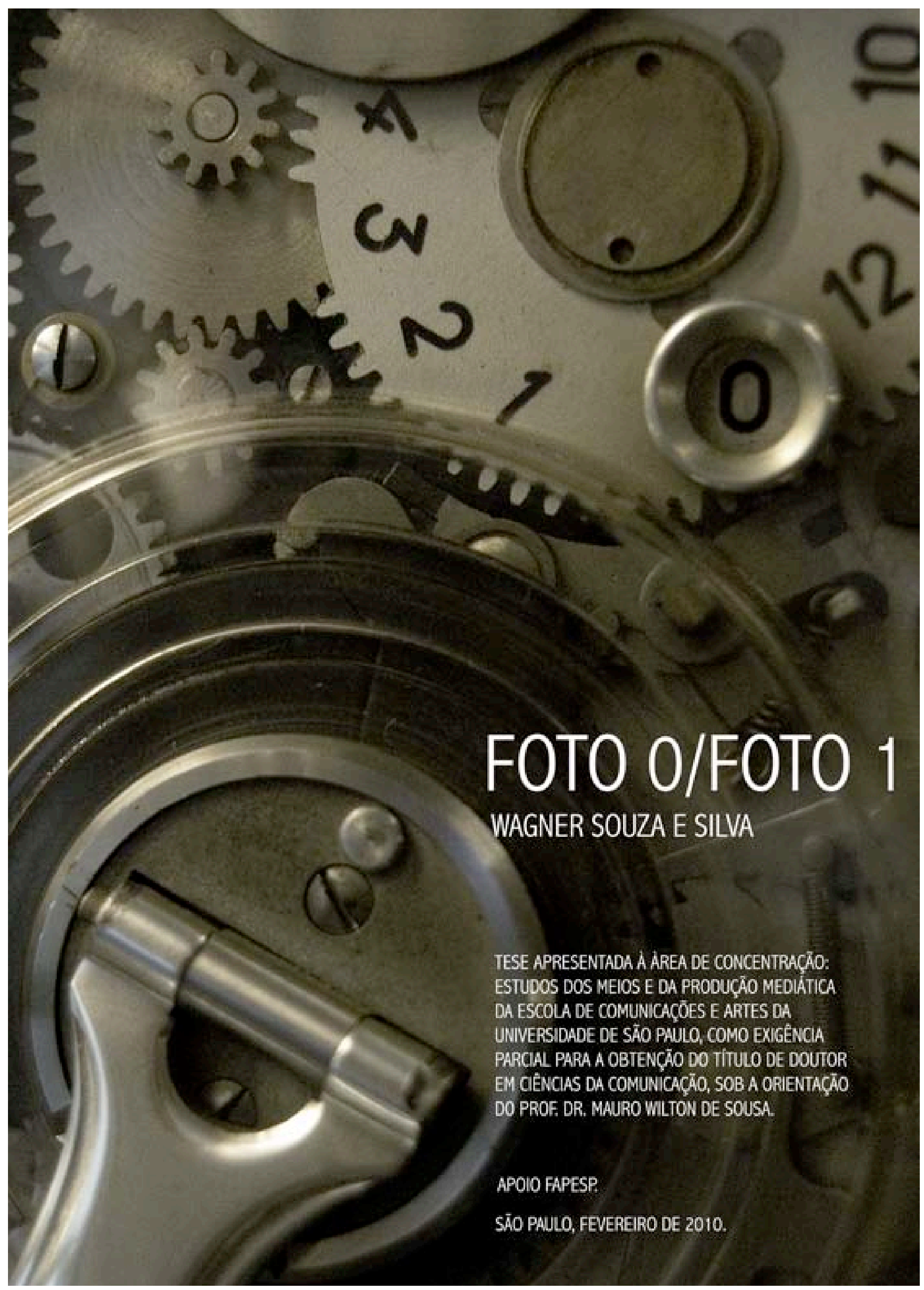


WAGNER SOUZA E SILVA

\section{FOTO 0/FOTO 1}

Tese apresentada à Àrea de Concentração: Estudos dos Meios e da Produção Mediática da Escola de Comunicações e Artes da Universidade de São Paulo, como exigência parcial para a obtenção do Título de Doutor em Ciências da Comunicação, sob a orientação do Prof. Dr. Mauro Wilton de Sousa.

São Paulo

Fevereiro de 2010 
BANCA EXAMINADORA 
Para Priscila,

a única pessoa deste mundo que não precisará ler esta tese para entender o seu real significado. 
AGRADECIMENTOS

A Mauro Wilton de Sousa, pela amizade e cumplicidade, e por sua incansável mania de provocar e inquietar.

A Arlindo Machado e a Norval Baitello Jr., pela generosidade e considerações valiosas no exame de qualificação.

A Joan Fontcuberta que, pela gentileza e atenção, só fez aumentar minha admiração pelo seu trabalho.

A Joe Struble, Todd Gustavson, Paul Pegnato, Susan Drexler e Rachel Stuhlman, da George Eastman House, pela assistência e precisas contribuições.

Aos amigos do MAE, que nunca deixaram de motivar e engrandecer essa busca.

À Jandyra Lobo de Oliveira, por mais uma vez socorrer-me de forma excepcional na revisão.

Aos meus diversos familiares que colaboraram, mesmo que de forma indireta: Nali, Lá, Zé, Sheila, Jarbas, Leandro e Cristiane.

Aos meus pais, José Lédson e llma, pelo apoio sempre incondicional.

A Raul, Manu e Dado, meus pequenos, que sempre me ensinam a grandiosidade de tudo.

Enfim, à FAPESP, pelo apoio ao projeto, e sobretudo ao parecerista, o qual não escondeu o objetivo de contribuir de forma bastante motivadora para este trabalho. 
Um sofista muito viajado pergunta a Sócrates: "Você continua aí dizendo sempre a mesma coisa. Assim torna as coisas fáceis para você." Sócrates responde: "Não, vocês sofistas é que facilitam, porque sempre falam de coisas mais novas e supernovas e sempre outra coisa. Mas o difícil é dizer a mesma coisa, e o mais difícil ainda: dizer a mesma coisa do mesmo."

Martin Heidegger $^{l}$

${ }^{1}$ HEIDEGGER, Martin. Seminários de Zollikon. Petrópolis: Vozes, 2009, p. 55. 


\section{RESUMO}

Desde seu surgimento, a fotografia e seu caráter híbrido, delineado pela conjunção entre ciência e arte, foi mais assimilada como ferramenta tecnológica a serviço desses conhecimentos, e não como um fenômeno originariamente capaz de questionar seus lugares dentro do pensamento ocidental; este, reflexo de um determinado projeto moderno de investigação e vivência. Tomandose como eixo de análise a pontuação de alguns aspectos de sua trajetória tecnológica e de sua inserção social, o presente estudo objetiva examinar bases filosóficas para a compreensão da fotografia em sua configuração digital contemporânea, apoiando-se em modelos interpretativos propostos por Roland Barthes e Vilém Flusser, mas também buscando aporte teórico no pensamento de Martin Heidegger. Entende-se que o universo digital, sobretudo se observados os processos de hibridação e as interconexões facilitadas por certas especificidades do numérico, estabelece a ambiência necessária para que a fotografia e seus desdobramentos, as tecnoimagens, possam ser usufruídas dentro de suas perspectivas mais originais e elementares.

Palavras-chave: tecnoimagem; fotografia; filosofia; tecnologia; comunicação. 


\begin{abstract}
Since its beginning, the photography and its hybrid nature, drawn by the conjunction of science and art, was treated more as a technological tool for service to those knowledges, and not as a phenomenon originally able to question their place in Western thought, this one understood as a reflexion of a particular modern project of research and experience. Taking as a point of analysis some aspects of their technological trajectory and their social integration, this study aims to examine philosophical basis for the understanding of photography in its digital contemporary setting, using the interpretative models proposed by Roland Barthes and Vilém Flusser, but also looking for support in the thought of Martin Heidegger. It is understood that the digital universe, especially when observing the processes of hybridization and the interconnections facilitated by certain characteristics of numeric, sets the ambience necessary for the photograph and its consequences, the techno-images, to be enjoyed within their prospects more original and elementary.
\end{abstract}

Keywords: techno-image; photography; philosophy; technology, communication. 
INTRODUÇÃO - 9

PARTE I A FOTOGRAFIA DO $O$ AO 1

1. ENTRE A TÉCNICA E A TECNOLOGIA - 14

2. CONSIDERAÇÕES SOBRE A TRAJETÓRIA TECNOLÓGICA DA FOTOGRAFIA - 23

3. DETERMINAÇÃO SOCIAL DE UMA PRÁTICA DE IMAGENS - 33

4. A DIFICULDADE DOS GÊNEROS - 41

5. DAS FOTOGRAFIAS À FOTOGRAFIA - 51

6. O MAPA DE FLUSSER - 60

PARTE II

A FOTOGRAFIA DO 1 AO 0

7. A PRIMEIRA FOTO - 70

8. O DIGITAL E A FOTOGRAFIA EM SISTEMA - 79

9. O ELOGIO DA CAIXA PRETA - 90

10. OCEANOS E TELAS - 98

11. AS DORES DA SUPERFICIALIDADE - 107

12. A FOTOGRAFIA E O PENSAMENTO MAIS DIFICIL - 117

13. ENSAIOS DO NADA - 127

CONCLUSÃO - 141

REFERÊNCIAS BIBLIOGRÁFICAS - 144

ANEXO: Entrevista com Joan Fontcuberta - 152 
A discussão sobre as alterações na prática fotográfica promovidas pelo numérico parece cada vez mais superada, pois cada vez mais também não cabe opção ao fotógrafo contemporâneo, seja ele amador ou profissional: as facilidades e os imediatismos do digital tornaram-se fundamentais para a cena comunicacional de produção de informações; ao mesmo tempo, a imposição do mercado fotográfico, tanto na esfera do consumo quanto no modus operandi da produção editorial em geral, dificulta qualquer tentativa de uso de uma película. Por que ainda então considerar tal transição tecnológica como objeto de estudo?

Segundo Couchot ${ }^{1}$, toda técnica supõe uma "experiência tecnestésica", isto é, uma técnica não é só um modo de produção, é "modo de percepção". É evidente que a experiência tecnestésica da fotografia ganha agora incremento em seus processos de construção e recepção. Isto pode ser constatado pelos softwares de tratamento que dilaceram as imagens, blogues e fóruns na internet criando ambientes de discussões, e também pela portabilidade e agilidade inseridas pelas câmeras compactas cada vez mais automatizadas e precisas. No entanto, propõe-

\footnotetext{
${ }^{1}$ COUCHOT, E. A tecnologia na arte: da fotografia à realidade virtual. Porto Alegre: Editora da UFRGS, 2003, p. 15.
} 
se aqui, antes de considerar a fotografia digital como nova experiência tecnestésica, considerar a experiência tecnestésica que a tecnologia digital promove na percepção da fotografia.

Isso é possível, pois os aparelhos de telefonia móvel, os tocadores de Mp3, as próprias telas dos microcomputadores com câmeras embutidas revelam-se como um arsenal de novas formas de conectividade, mas que são também novas formas de aproximação à fotografia. Fred Ritchin, em After Photography, ao afirmar que "nós entramos na era digital; e a era digital nos adentrou"2, demonstra que o "0" e o "1" não são exclusividades da fotografia, e por esta mesma razão devem-se supor novas atribuições para a sua prática, pois agora, imersa em outros dispositivos, a sua tecnologia perdeu muito de seu apelo singular, conectando-se, hoje, com um universo material que já não é mais específico de sua constituição original.

Cabe lembrar que, no meio profissional, discursos inflamados pela defesa da película permearam os anos iniciais da introdução da imagem digital, nessa época, esta ainda se mostrava com qualidade muito inferior se comparada ao processo fotoquímico. Naquele momento, a fotografia digital foi vista com maus olhos por aqueles que prezavam a qualidade técnica e toda a laboriosidade do processo fotográfico convencional, já que a nova tecnologia parecia coisa de amador, parente muito próximo do vídeo caseiro. Não se poderia, naquele tempo, dizia-se no meio profissional, comparar suas imagens facilmente obtidas com as imagens fotoquímicas que exigiam todo um conhecimento para o bom aproveitamento de uma película fotográfica.

Esse momento evidenciou que uma ideia de "boa fotografia" também sempre passou pela ideia de um domínio tecnológico; revelou, portanto, que muito do que define o valor das fotografias também dependia da tecnologia da fotografia, e não somente do conteúdo da imagem resultante. 0 daguerreótipo, por exemplo, uma placa de cobre polida e apresentada em um belo estojo, já foi considerado verdadeira "joia"; o calótipo e sua textura peculiar, devido a ser uma transparência em papel fibroso, criava imagens com menor nitidez e por isto valoradas no sentido de se aproximarem da arte pictórica; o mesmo vale para as polaroids, descartáveis para uns, que se tornaram valiosas obras de arte para outros. E no que coube às máquinas, pode-se apontar a Leica ou a Speed Graphic como mitos no fotojornalismo, a Hasselblad e sua qualidade óptica, ou até mesmo as peculiaridades das pequenas brownies da Kodak.

${ }^{2}$ RITCHIN, Fred. After Photography. New York: W.W. Norton \& Company, 2009. 
Toda tecnologia determina, em certa medida, aspectos que circundam a valoração da imagem. Mas, nesse sentido, qual o valor que se pode atribuir às fotografias no universo digital, quando hoje as imagens são determinadas por cargas elétricas, os pixels, e por câmeras que cada vez mais caminham para uma padronização estrutural?

Sabe-se que agora tudo tende a ser muito mais simples e ágil, e as imagens são produzidas dentro de uma perspectiva de uso banal que não parecia caber nos objetivos dos atos fotográficos que buscavam as "boas fotografias" e que, para isto, exigiam domínio tecnológico. Cada vez mais se vê que não é preciso recorrer ao entendimento das lógicas operacionais da tecnologia, dada a sofisticação de simplificação introduzida pelo universo digital. É certo que George Eastman, fundador da Kodak, por exemplo, já teria inaugurado essa possibilidade de despojamento com seu parque tecnológico doméstico; mas o que ocorre nos dias atuais é mais expressivo devido a certas especificidades do numérico, o qual este estudo pretende explorar para comprovar a seguinte tese: no processo fotográfico tradicional, a maneira como o sujeito operava sua relação com o real por meio das imagens se confundia com a maneira com que 0 sujeito operava sua relação com a tecnologia fotográfica; no digital, parece não haver mais essa confusão. A imagem fotográfica, portanto, parece estar apta a revelar o seu valor mais originário e fundamental.

Existia até recentemente um distanciamento entre imagem e realidade, sobretudo devido à necessidade de processos químicos e também pela necessidade de domínio técnico, ambos fortalecendo estas duas pontas do processo: a imagem sempre seria uma surpresa investida de mágica, pois carregada de imprevisibilidades, antes de tudo por inevitavelmente estar temporalmente distante do momento vivido que a originou; ao mesmo tempo, o momento vivido seria sempre ficcionalizado no tempo presente da contemplação da imagem. Mas agora, essa instrumentalização tecnológica, aprimorada e estancada nos aparelhos digitais, exigindo cada vez menos o compromisso operacional, compactua com a instrumentalização da imagem, tornando imediata essa operação entre sujeito e real.

Segundo Lissovsky33, a fotografia moderna parece estar "encerrando um ciclo de criação". Ao mesmo tempo, observa-se que as imagens digitais podem ser "inseridas em circuitos mais amplos de sentido", possibilitando o seu uso como "instrumento de novas maneiras de se

\footnotetext{
${ }^{3}$ LISSOVSKY, Maurício. 0 tempo e a originalidade da fotografia moderna. In: Doctors, M. (org.). Tempo dos tempos. São Paulo: Jorge Zahar, 2003, pp. 142-165.
} 
pensar o mundo e o sujeito" 4 . É possível afirmar que a prática fotográfica contemporânea ainda esteja oscilando entre esse encerramento moderno e essa possível nova instrumentalidade. E a observação da transição tecnológica, apesar de cada vez mais difícil de ser abordada empiricamente, é ainda pertinente por representar possibilidade de apreender a fotografia entre fases de adequação. Assim encarada, ela estaria "suspensa", e sua prática, indefinida em alguns sentidos, mas preservando, nesse processo, o seu aspecto constituinte mais fundamental.

Antes de ser prática de imagem, a fotografia é a prática de uma tecnologia. Se a fotografia contemporânea carrega consigo novos aspectos capazes de redesenhar o seu uso, muito se deve aos reflexos dessa remodelação digital da sua matéria tecnológica que a estrutura. 0 objeto do presente trabalho se constituirá pela reflexão a respeito de tal processo de transição dentro da trajetória tecnológica da fotografia, propondo uma análise de seus reflexos na construção identitária de sua prática contemporânea. Tem-se, como estratégia metodológica, o confrontamento de biblbiografia de críticas a respeito com a observação de produções fotográficas oportunas para o desenvolvimento do tema.

Propõe-se, na estruturação do texto, duas grandes partes: a fotografia do zero ao um, que buscará, nos capítulos iniciais, refletir sobre alguns aspectos da prática fotográfica com películas; e em seguida, nos capítulos sequentes, a fotografia do um ao zero, mais concentrada na sua configuração digital contemporânea. Mas esta proposta não pode ser interpretada somente como duas fases distintas da fotografia, tanto que o movimento é circular aqui: ela sai do zero, vai ao um, para em seguida voltar ao zero. É sim uma tentativa de se criar uma ordem cronológica para a trajetória da fotografia, mas dadas certas especificidades da técnica, uma resistência parece surgir quando se intenta tal linearidade histórica: muito do que define a fotografia digital está na fotografia com película, e o contrário também parece ocorrer.

0 fato é que, nessa troca de roupagens tecnológicas, a fotografia está "despida". Talvez, neste momento, assim fragmentada, desconstruída e volátil como está ao adentrar nos "zeros" e "uns", a fotografia permita, finalmente, que se perceba aquele "novo"5 do qual ela pode ter sido advento para o universo das imagens.

\footnotetext{
${ }^{4}$ LUZ, R. Novas imagens: efeitos e modelos. In: PARENTE, André. Imagem máquina: a era das tecnologias do virtual. Rio de Janeiro: Editora 34, 1993, p. 53.

5 BARTHES, Roland. A câmara clara. Rio de Janeiro: Nova Fronteira, 1984, p. 13.
} 


\section{PARTE I}

A FOTOGRAFIA DO 0 AO 1 


\section{ENTRE A TÉCNICA E A TECNOLOGIA}

Existem duas maneiras "profundamente diferentes de conhecer uma coisa (...) a primeira implica que rodeemos a coisa; a segunda que entremos nela" I. A assertiva de Henri Bergson é oportuna, pois permite revelar o contexto de abordagem que aqui se pretende. Se é verdade, portanto, que são dois os modos de aproximação de um objeto quando se intenta a sua observação, quando este pode ser visto por fora ou visto por dentro, ao abordar a fotografia como fotógrafo, a oscilação por entre estas duas maneiras torna-se inevitável. 0 olhar de dentro surge pela prática acumulada ao longo do tempo, e o olhar de fora, pelo questionamento direcionado às motivações e aos sentidos que tanto provocaram ou foram provocados pelos incontáveis atos fotográficos construídos. Tal como parece ser fundamental num processo de pesquisa científica, não existe, então, distanciamento do objeto. Como aqui se propõe um momento de reflexão a respeito da fotografia, mas sob a influência de uma práxis que já se

\footnotetext{
${ }^{1}$ BERGSON, Henri. Introdução à metafísica. In: Cartas, conferências e outros escritos. São Paulo: Nova Cultural, 2005, p. 21.
} 
estende por quase quinze anos ${ }^{2}$, o objeto de estudo ganha uma dimensão mais complexa quando duas formas de abordagem, interna e externa, surgem simultaneamente.

É por tal razão que a observação da tecnologia da fotografia parece ser um caminho para permitir esta dualidade de abordagem, já que lida com o universo da prática propriamente dita, ao trazer a lógica funcional dos objetos e processos desse modo de se compor imagens, e permitir investigar as bases teórico-filosóficas das relações entre o sujeito e a realidade, porquanto é a concreção das motivações que envolvem o saber e fazer fotográficos. Além do que, pode-se apontar a tecnologia como ponto de ancoramento dos debates sobre a contemporaneidade da prática, pois é ali que o universo digital age numa possível redefinição de paradigmas para o uso da fotografia.

A princípio, vale considerar a tecnologia da fotografia como objeto de estudo fundamental dentro das práticas de funcionamento da comunicação contemporânea, visto que sua estrutura carrega a gênese dos principais dispositivos capazes de produzir imagens audiovisuais. Graças à cadeia operacional que foi sistematizada com o seu advento, foi possível a construção das câmeras cinematográficas, que se utilizam de películas, bem como das câmeras videográficas, de captação eletrônica.

Todo esse aparato levou à estruturação de um universo audiovisual mais amplo permeado por múltiplas telas, múltiplas câmeras, múltiplas imagens: tecnologias que possuem uma mesma ascendência e encontram na técnica fotográfica um ponto comum de convergência. $E$ complementando a assertiva de Deleuze de que a televisão e o vídeo são meios servis ao cinema $^{3}$, seria possível dizer que, na verdade, todos esses três meios servem à fotografia. Sempre vale a pena, portanto, retomar com destaque a precisão de Arlindo Machado na identificação da fotografia na genealogia tecnológica das imagens contemporâneas:

A fotografia é a base tecnológica, conceitual e ideológica de todas as mídias contemporâneas e, por essa razão, compreendê-la, defini-la, é um pouco também compreender e definir as estratégias semióticas, os

\footnotetext{
${ }^{2}$ Grande parte desta prática se deu na atuação deste autor como fotógrafo do Museu de Arqueologia e Etnologia da USP, entre os anos de 1998 e 2008. Trata-se de uma experiência com a fotografia muito determinada por seu caráter documental, uma vez que o grosso das imagens produzidas do acervo do museu era destinado a artigos científicos, relatórios e laudos técnicos. No entanto, as mesmas imagens poderiam também ser destinadas à catálogos de exposições, o que determinava a preocupação sempre presente de garantir o apelo estético das imagens dos artefatos fotografados, obrigando a constância do diálogo entre arte e ciência. Somando-se a este contexto de trabalho o fato de que, nesses anos, deu-se o processo de entrada da fotografia no universo digital, tal prática é o que circunda, portanto, a motivação para esta reflexão.

3 "É por isso que não acredito na morte do cinema em favor da televisão ou do vídeo. Todo novo meio lhe serve." In: DELEUZE, Gilles. Conversações. Rio de Janeiro: Editora 34, 1992, p. 71.
} 
modelos de construção e percepção, as estruturas de sustentação de toda a produção contemporânea de signos visuais e auditivos, sobretudo daquela que se faz através de mediação técnica. ${ }^{4}$

"Cada vez que um meio novo é introduzido", segue o autor, "ele sacode as crenças anteriormente estabelecidas e nos obriga a voltar às origens para rever as bases a partir das quais edificamos a sociedade das mídias". E a ambiência em que se dão as "sociedades das mídias" nos dias que correm vem sendo compreendida em meio à ideia das TIC's, que ora são denominadas como Tecnologias da Informação e Comunicação, ora como Técnicas da Informação e Comunicação.

De imediato, a perspectiva dess dupla denominação das TIC's sugere um ponto de partida, pois uma breve reflexão sobre as noções que se podem atribuir aos termos técnica e tecnologia parece ser um caminho possível para se buscar a revisão das bases edificadoras, sugeridas por Machado, que estruturam os modelos interpretativos do papel da fotografia. Até porque muito se fala sobre a "técnica de um fotógrafo" ou sobre a fotografia como tecnologia ou técnica; muito se fala sobre o caráter técnico-científico da fotografia: a própria introdução apresentada nesta tese fez uso indiscriminado dos termos técnica e tecnologia, confundindo-os em certos momentos; porém, parece existir uma diferença entre ambos que, apesar de extremamente sutil, os evidencia como conceitos distintos.

Álvaro Vieira Pinto, por exemplo, traz essa preocupação ao admitir quatro linhas de definição para tecnologia55: o estudo ou a teoria da técnica; como sinônimo da técnica; como o conjunto de técnicas de que dispõe uma determinada sociedade, em qualquer fase histórica de seu desenvolvimento; e por último, como ideologização da técnica, revelando assim a pertinência da necessidade de reflexão sobre o uso descompromissado de tais termos.

Segundo Bernard Miège ${ }^{6}$, no universo da língua francesa, technologie é um termo que aproxima-se muito mais de uma ideia de discurso sobre a técnica, e technique apontaria em direção a uma esfera prática de atuação. Miège entende, portanto, as TIC's como "Técnicas da Informação e Comunicação", e não como "Tecnologias", e isto, em sua visão, permitiria evitar a tendência para aquilo que ele denominou como tecno-determinismo, ou seja, evita-se justamente

\footnotetext{
4 MACHADO, Arlindo. A fotografia como expressão do conceito. Studium, Unicamp, 2000. [www.studium.iar.unicamp.br/2]. Acessado em 17/8/2003.

${ }^{5}$ PINTO, Álvaro Vieira. O conceito de tecnologia. Rio de Janeiro: Contraponto, 2005, volume 1, p. 219.

${ }^{6}$ Discussão em sala de aula de seu curso "As tecnologias da informação e comunicação: entre inovação técnica e inserção social", ministrado na ECA/USP em abril de 2009. Tal curso, conforme anunciado por Miège, foi baseado em seu livro, recentemente traduzido no Brasil, "A sociedade tecida pela comunicação" (2009).
} 
a concepção das TIC's como um objeto de estudo sustentado unicamente por determinações tecnológicas que facilmente podem ser sobrepostas aos processos sociais que ali também estão envolvidos. Essa distinção estaria próxima do que também ocorre na língua inglesa, em que technology apontaria para o conjunto de instrumentos materiais e da teoria necessária para operá-los, e technique procuraria abranger o emprego desses instrumentos, bem como a capacidade daqueles que os usam ${ }^{7}$.

Nota-se que, tendo em vista tais apontamentos, o termo técnica sugere conexão mais íntima com as necessidades e as motivações da práxis, enquanto tecnologia corresponde aos aparatos e aos discursos que estipulam os modos de atuação. Portanto, uma técnica, isto é, uma lógica operacional da ação humana em função de um desejo, exige uma tecnologia para ser operacionalizada. Técnica e tecnologia, apesar de serem indissociáveis, apresentam uma hierarquia existencial que deve ser notada: a técnica origina tecnologia, ao mesmo tempo que não existe tecnologia que não esteja a serviço de uma técnica.

Assume-se aqui, portanto, que tecnologia é a conjunção do material e da teoria que foram originados por uma técnica, sendo que esta corresponde à expressão prática da necessidade e desejo que levam a uma ação. Dentre as quatro categorias propostas por Álvaro Vieira Pinto, toma-se aqui o conceito de tecnologia como a "teoria da técnica". Ainda no entender deste mesmo autor, tal opção aponta o primeiro significado etimológico como o "logos da técnica", isto é, "a teoria, a ciência, o estudo, a discussão da técnica, abrangidas nesta última noção as artes, as habilidades do fazer, as profissões e, generalizadamente, os modos de produzir alguma coisa"8. A assertiva se apoia, por conseguinte, na discussão que abarca os reflexos do fato de a técnica ter se tornado ciência ou, etimologicamente falando, das consequências originadas da associação entre os conceitos gregos de techné e logos. Rudiger sustenta:

Os fundamentos da técnica, agora, pouco a pouco deixam de residir numa habilidade humana. Apenas as belas artes, cujo conceito desponta, mas não por muito tempo, essa referência à excelência ou capacidade de aperfeiçoamento humano. No restante, a concepção e os fundamentos do que se entende por técnica serão físico-matemáticos. A expressão tecnologia paulatinamente iniciará seu império enquanto conjunto de discursos que visa a se constituir como ciência da construção de meios para produzir efeitos previamente calculados: isto é ciência da técnica, a técnica da criação e emprego científico de todos os meios de ação

\footnotetext{
${ }^{7}$ Jacques Aumont sustenta essa diferenciação em A imagem. Campinas: Papirus, 1993, pp. 178-179.

8 PINTO, op. cit.
} 
possíveis. Verifica-se, portanto, que, assim, culmina um processo secular em que o conceito de técnica, forjado pelos antigos gregos, passou por uma formidável interpretação prática e teórica e ao cabo da qual seu campo de atuação passou a ser melhor definido como objeto de tecnologia. $^{9}$

Quando, por exemplo, Heidegger ressalta o caráter ontológico da técnica, mesmo sem apontar para o termo tecnologia, sustenta uma diferenciação entre a techné grega (como poiésis, criação) e a técnica moderna com suas implicações em função de sua relação com a ciência ${ }^{10}$. Uma vez que tecnologia traz a inserção do termo logos (razão, conhecimento, discurso) ao termo techné, não estaria Heidegger questionando justamente a diferença entre técnica e tecnologia?

Ao se notar a presença inevitável da ciência, vê-se que o termo tecnologia deve ser compreendido não só pela materialidade dos dispositivos, mas também como potencial discurso que parece ir além das lógicas operacionais envoltas na práxis. Flusser, que será retomado com maior afinco em capítulos mais à frente, afirma que o "milagre da técnica não passa de caso especial do milagre maior da práxis" que é, no dizer do filósofo, "a capacidade humana de mergulhar sua mão para dentro da realidade", crendo, assim, que "o núcleo de todo o verdadeiro marxismo é humanizar a técnica e evitar a tecnologização do homem"11.

Tal preocupação pela "tecnologização do homem" é reflexo da percepção do distanciamento da técnica com as reais motivações que fundamentaram a sua criação e que justificam seu uso. 0 esquecimento do porquê da técnica e o mergulho nos maquinismos e tecnicismos - vale dizer, na tecnologia - , promovem um uso pseudonecessário, visando somente a atingir fins que se encerram num movimento interno, sem conexão com o desejo e o objeto desejado, sobretudo num contexto em que o consumo é desenfreadamente facilitado pela oferta ostensiva de produtos tecnológicos.

Tomando-se como exemplo o acervo do Musée Français de la Photographie ${ }^{12}$, pode-se constatar toda a evolução da técnica que sustentou a criação das tecnologias fotográficas.

\footnotetext{
${ }^{9}$ RUDIGER, F. Origens: técnica e tecnologia. In: Introdução às teorias da cibercultura. Porto Alegre: Sulina, 2003, pp. 25-35.

${ }^{10}$ HEIDEGGER, Martin. A questão da técnica. In: Scientiae Studia, volume 5, n. 3. São Paulo: Faculdade de Filosofia, Letras e Ciências Humanas da Universidade de São Paulo, [1953] 2007, pp. 375-398.

${ }^{11}$ FLUSSER, Vilém. Bodenlos: uma autobiografia filosófica. São Paulo: Annablume, 2007, p. 217.

${ }^{12}$ Trata-se de viagem de campo realizada por este autor em junho de 2008, por meio dos recursos disponibilizados pela FAPESP. 0 Musée Français de la Photographie (MFP) localiza-se no Departement de L'Essonne, próximo à cidade de Paris. Apesar de pequeno, possui acervo de mais de 25.000 objetos entre câmeras e acessórios que contam toda a história tecnológica da fotografia. É possível revisitar desde as objetivas utilizadas pelo próprio Louis Daguerre até os aparelhos de telefonia celular contemporâneos que carregam câmeras fotográficas digitais. Essa riqueza encontra-se disposta em diversas vitrines abarrotadas de objetos, o que permite a visualização e a comparação in loco de vários aspectos dos equipamentos, sobretudo quanto a dimensão, robustez e lógica funcional. Web site: http://www.photographie.essonne.fr
} 
Câmeras que diminuíram drasticamente de tamanho, superfícies fotográficas que foram sendo cada vez mais aprimoradas em direção a uma volatilidade aparentemente inevitável (do metal ao pixel, passando pelo papel e celuloide), diversos dispositivos e acessórios mecânicos que hoje representam uma parafernália que não faz sentido para a prática contemporânea: muito daquilo que se entende por fotografia vem dessa presença massiva da tecnologia constituindo e aprimorando o saber e fazer fotográficos. Necessária parece uma observação mais atenta do que seriam exatamente as motivações que levaram à criação dessas tecnologias, visando a investigar o que seriam os fundamentos da técnica da fotografia, isto é, o porquê de se fotografar.

Pode-se inicialmente considerar que a técnica fotográfica surgiu como forma de atender ao desejo da máxima perfeição na representação figurativa, ideal de imagem que sempre esteve presente nas pretensões pictóricas ao longo da história da arte. É o que aponta Jean-François Groulier, quando observa que a frase de Aristóteles - "A arte imita a natureza" - tenha sido um "princípio inabalável na prática da pintura até muito recentemente"13.

A fotografia foi evolução natural dentro de uma perspectiva de atuação que objetivava a precisão no ato de feitura de imagens. 0 uso da câmera escura, evidente a partir do Renascimento, prova tal constatação ${ }^{14}$. Mas até o surgimento da fotografia, todo o mérito do artista era ainda sustentado pela sua capacidade em executar a obra, isto é, reconhecia-se sua técnica independentemente da tecnologia utilizada. Quanto mais próximo fosse a arte do real, reconhecia-se a habilidade técnica do artista que, pode-se até afirmar, seria sinônimo de sensibilidade. Apesar de apontar um contexto anterior, a passagem de Leonardo da Vinci pode servir como síntese:

E de fato, tudo que existe no universo em essência, presença ou imaginação ele os tem primeiro na mente, e então nas mãos, e estas têm tanta excelência que, num dado momento, geram uma harmonia de

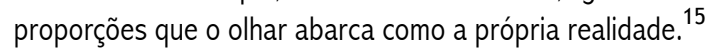

A fotografia, quando surgiu, não exigia sensibilidade ou habilidade da mesma forma que era exigida na arte pictórica. Se colocado nos termos da discussão aqui empreendida, ver-se-á

\footnotetext{
${ }^{13}$ LICHTENSTEIN, Jacqueline (org.). A pintura: da imitação à expressão. São Paulo: Editora 24, 2004, p. 9.

${ }^{14} \mathrm{Em} A$ ilusão especular (1984), Arlindo Machado considera, inclusive, que a fotografia teria sido criada neste momento da história das artes: "a invenção da fotografia não pode ser confundida com a descoberta das placas sensíveis à luz e por isso a data de 1826 (quando Niépce registra ou fixa a imagem na chapa fotográfica pela primeira vez) é arbitrária para designar 0 nascimento do processo. A fixação fotoquímica dos sinais de luz é apenas uma das técnicas constitutivas da fotografia; a câmera fotográfica, porém, já estava inventada desde o Renascimento, quando proliferou sob a forma de aparelhos construídos sob 0 princípio da camera obscura" (p. 25).

${ }^{15}$ LICHTENSTEIN, op. cit., p.47.
} 
que a fotografia surgiu como tecnologia. Não era preciso ser dotado de habilidade, isto é, de "excelência nas mãos" para a produção desse novo tipo de imagem, mas ser dotado de conhecimento sobre como operar o novo instrumento. No entanto, ao ultrapassar os resultados pretendidos por um realismo pictorial, colaborou para a reconfiguração das motivações da arte pictórica, o que pode ser facilmente constatado pelos diversos movimentos artísticos ao longo do século XX que buscaram, grosso modo, evitar a via da precisão na arte de representar. A fotografia, sendo apenas uma tecnologia, foi abandonada à sua própria sorte no campo da expressão, onde sua objetividade, a sua precisão como mecanismo de representação, encontrou dificuldades para ser reconhecida como arte.

Tal fato pode ser constatado levando-se em conta a tese de Dobranzky, de que a sua entrada legitimada institucionalmente nesse universo deu-se com a primeira exposição fotográfica no Museum of Modern Art de Nova York somente em 1933, com imagens de Walker Evans ${ }^{16}$, quase cem anos após a sua invenção. Mas mesmo o movimento fotográfico straight photography, em destaque na época, e no qual poderia ser enquadrado o trabalho de Evans, teria sido suficiente para reverter essa condição de mecanismo e inaugurar um traço próprio de existência?

0 straight photography ${ }^{17}$, movimento que pregava uma "fotografia pura", é considerado como forma de refutação ao pictorialismo fotográfico do início do século, este que normatizava uma arte fotográfica dentro dos mesmos padrões estéticos da pintura, seja pela absorção de seus gêneros (paisagem, retrato, natureza morta, etc.), seja pelas intervenções físicas nos negativos com a finalidade de gerar imagens que burlassem a objetividade fotográfica. Costa $\&$ Silva asseveram:

16 "A percepção da fotografia como meio expressivo teve como marco sua aceitação nos museus de arte. Em 1933, o MoMA (Museum of Modern Art) de Nova York abrigou a primeira exposição fotográfica da história realizada dentro desse tipo de espaço institucional reservado estritamente para obras de arte. 0 fotógrafo escolhido foi Walker Evans. Dessa forma, o MoMA recebeu a fotografia em seu campo de criação puro e afirmou categoricamente: fotografia é arte". In: DOBRANSZKY, Diana de Abreu. $A$ fotografia entre a arte e a máquina. Disponível em www.studium.iar.unicamp.br/21. Acesso em 15/8/2006.

17 Movimento da "fotografia direta" ou fotografia assumida, numa tradução aproximada, e que tem como início a publicação de ensaio do fotógrafo Paul Strand (1890-1976) na Camera Work, em 1917, que trazia fotografias produzidas nas ruas de Nova York. "Depois de tirada, a fotografia está concluída" AMAR, Pierre-Jean. História da Fotografia. Lisboa: Edições 70, 2007, p. 91.

${ }^{18}$ COSTA, Helouise \& SILVA, Renato Rodrigues da. A fotografia moderna no Brasil. São Paulo: Cosac Naify, 2004, pp. 26-27. 
De acordo ainda com os mesmos autores, os pictorialistas, ao tentarem elevar a fotografia à categoria de arte, "forjavam uma estética" que pretendia "destruir o caráter revolucionário do meio de expressão". Atacavam a "cientificidade fria da imagem fotográfica", intervindo com lápis, borracha e pincéis para a introdução e supressão de elementos, com um alto nivel de sofisticação, além de atacarem a "democratização dos procedimentos técnicos e a reprodutibilidade infinita da imagem". 19

0 straight photography assumia a objetividade da técnica, mas ainda num clima de reverberação do embate entre arte pictórica e fotografia, visto que refutava o pictorialismo. Apesar de iniciar a busca de traços específicos para o desenvolvimento da fotografia como meio de expressão, o movimento trouxe também um certo discurso tecnicista que passaria a ganhar evidência, tal como pode-se apreender a partir da influência da prática de Ansel Adams, por exemplo, igualmente um "straight photographer".

Adams talvez tenha sido um dos fotógrafos que mais buscaram enaltecer a fotografia por meio da celebração dos procedimentos tecnológicos de constituição, insistindo neste ponto como principal pilar sustentador de uma possibilidade para um caráter próprio da prática. Suas imagens não representavam o dinamismo das cidades, tal como se vê em Paul Strand: ao fotografar paisagens, particularmente, Ansel Adams parece ter sentido ainda mais a necessidade de justificar a fotografia pela tecnologia, pois lidava com um gênero consagrado na pintura. Publicou textos como Making a photography (1935), The camera and lenses (1948), The negative (1948) e The print $(1950)^{20}$, os quais se tornaram verdadeiras doutrinas para se estabelecer uma ideia de "boa fotografia" a partir de um discurso tecnodeterminista concentrado na "nitidez da realidade", confundida com uma "fidelidade de reprodução". Pregava-se prioritariamente a pureza da imagem fotográfica. Adams foi, inclusive, um dos fundadores do grupo "f64", nome que demonstrava que os seus membros se esforçavam em buscar sempre tal nitidez pela "profundidade de campo", tal como sugerido pela pequena abertura de diafragma indicada pela sigla do grupo. ${ }^{21}$

Por tais razões, pode-se considerar que, mesmo sendo reconhecida como arte quando adentrou em espaços institucionalmente legitimadores, a fotografia se sustentou como tecnologia

\footnotetext{
${ }^{19}$ Idem.

${ }^{20}$ Cabe dizer que, graças ao apoio da FAPESP, foi possível a este autor verificar com mais afinco a postura de Ansel Adams, em viagem de campo à George Eastman House, em Rochester (NY), em dezembro de 2009, também financiada pela FAPESP. Lá, além de consultar as primeiras edições de seus textos, em especial Making a Photography de 1935, houve a possibilidade de apreciar imagens processadas pelo próprio fotógrafo que se encontram no acervo da instituição.

${ }^{21}$ TAUSK, Petr. Historia de la fotografia en el siglo XX. Barcelona: Gustavo Gili, 1978, pp. 57-61.
} 
que atendia a um desejo humano, o da representação, mas ainda dentro de um clima de embate com o universo pictórico. E mesmo que o movimento da straight photography tenha iniciado a definição de certas especificidades da fotografia como meio de expressão, a tecnologia da fotografia teria sido ainda muito celebrada. E decorre de tal constatação que este movimento de "afirmação da fotografia", na sua essência, não teria sido tão diferente do pictorialismo, pois ambos traziam como base constitutiva de seus discursos a arte pictórica como referência.

Exige-se aqui uma percepção que beira ser forçosa, é verdade, mas que está na esteira dessa sutileza maior de se afirmar a distinção entre técnica e tecnologia. Em síntese: deve-se notar que a fotografia, em seu início, foi considerada muito mais uma tecnologia para atender aos processos de representação pictórica do que uma técnica definida por desejos e motivações próprias. Sua objetividade, seu caráter tecnológico foi sendo paulatinamente digerido a partir da dificuldade inicial em aceitar as suas imagens de grande nitidez como forma de arte. 0 pictorialismo é a maior evidência do ápice dessa "indigestão"; o straight photography é o primeiro passo de superação que se deu ao longo do século XX. Neste momento contemporâneo a fotografia, agora digital, já estaria "digerida".

A partir das raizes etimológicas dos termos técnica e tecnologia, propõe-se assumir, então, que a fotografia, até a inserção no digital, era muito mais tecnologia do que técnica, sendo que após sua entrada no numérico, caberia indagar se não se torna mais técnica do que tecnologia, dadas as simplificações introduzidas na sua lógica operacional e nos aparatos para a produção de suas imagens.

Isto posto, deve-se buscar, portanto, essa diferenciação entre os elementos técnicos e tecnológicos da fotografia. E visando a expandir e fundamentar tal ideia, a seguir serão apontadas breves considerações sobre a história tecnológica da fotografia, por meio da descrição dos principais processos e equipamentos para registro até antes de sua entrada expressiva no numérico, ou seja, do daguerreótipo, de 1839, ao sistema APS (Advanced Photo System), de 1996. 


\section{CONSIDERAÇÕES SOBRE A TRAJETÓRIA TECNOLÓGICA DA FOTOGRAFIA}

A fotografia, como técnica de produção de imagens, desde seu início mantém a mesma cadeia de ação que estabelece os seus procedimentos de uso. Essa cadeia de eventos mantémse como aquilo que pode ser entendido como constituinte de qualquer sistema fotográfico de qualquer época, e de qualquer parte do mundo. Grosso modo, tal caráter universal, na sua concepção mais simples, consiste numa caixa com uma entrada de luz que pode ser controlada.

A primeira etapa de controle consiste em direcionar os raios luminosos que adentrarão na caixa preta. Todo objeto, seja ele uma fonte luminosa ou não, emite raios de luz, pois mesmo nos objetos sem luz própria, emana-se luz refletida. 0 que se enxerga é luz, o que é o mesmo que excita a superfície em que se formará a imagem fotográfica. Quanto mais comportada for essa luz, mas nítido é o objeto. "Comportada" significa direcionada, sem dispersões, e isto é obtido nas câmeras fotográficas pelas estruturas de lentes convergentes e divergentes que estão ao longo de um canal de entrada. Aquilo que o senso comum denomina como lente é, na verdade, um agrupamento de lentes que visam a "filtrar" e concentrar os raios dispersos que por ali passam, sendo que para este conjunto de lentes posicionadas ao longo deste "túnel de entrada" dá-se o nome de objetiva. A segunda etapa de controle determina o raio do orifício que permitirá a entrada da luz. Quanto maior o raio, maior é a dispersão de luz, e quanto menor o raio, menor é a dispersão, e consequentemente, maior nitidez será possível. Mas devido à presença das 
lentes auxiliando na concentração da luminosidade, mesmo na maior circunferência de entrada, a saber, na maior abertura, é possível obter uma imagem nítida no plano fotossensível. 0 que a menor abertura provoca é a possibilidade de expandir essa nitidez em profundidade, ou seja, o que está antes e depois do motivo selecionado como imagem. A este mecanismo de controle de abertura dá-se o nome de diafragma (uma pequena abertura seria a indicada pelo f64, nome do grupo de Ansel Adams, descrito anteriormente). A terceira etapa de controle consiste em determinar por quanto tempo a luz ficará em contato com a superfície fotossensível. Esse tempo pode variar de frações de segundo a minutos, horas ou dias. A este mecanismo dá-se o nome de obturador ${ }^{1}$.

Para determinar o tipo de objetiva, a abertura do diafragma e o tempo do obturador deve-se levar em conta diversos aspectos do material constituinte da superfície fotossensível. A história da tecnologia da fotografia é um pouco determinada pelas possibilidades originadas pelo aperfeiçoamento das estruturas dessas superfícies. Todo o suporte material correspondente à estrutura da câmera fotográfica foi sendo redimensionado à medida que estas superfícies foram sendo aprimoradas.

0 suporte da imagem fotográfica pode ser considerado, em muitos aspectos, ponto convergente e irradiador de mudanças na tecnologia e na sua prática. E pode-se notar um dado importante para corroborar tal determinação: o que se considera como invenção ou descoberta da fotografia em 1839 é justamente o momento em que a luz proveniente de uma cena do real é aplicada e fixada numa superfície material, ainda que os princípios ópticos da câmera mecânica já tivessem sido utilizados desde muito antes, devendo-se observar não só o uso da câmera escura em larga escala para objetivos pictóricos a partir do século XV, mas também o relato de Aristóteles a respeito do uso desse tipo de equipamento na observação de um eclipse solar ainda no século IV a.C. ${ }^{2}$

Encarando-se a tecnologia do processo como fator determinante na estruturação da tecnologia da máquina, torna-se necessário apontar tal dialética que parece ter sido a constituição do universo tecnológico fotográfico. Vale dizer, a cada avanço expressivo da tecnologia do suporte fotográfico, foi permitido ao mecanismo ter formas de adaptação correspondentes. Torna-se oportuno, primeiramente, abordar os suportes.

\footnotetext{
${ }^{1} 0$ obturador pode, na verdade, estar à frente ou após o diafragma, e isto depende do modelo da câmera. HEDGECOE, John. 0 Manual do fotógrafo. Porto: Porto Editora, 1982, pp. 10-11.

2 AMAR, Jean-Pierre. Op. cit, p. 12.
} 
0 primeiro processo dessa suposta "história da fotografia" foi o daguerreótipo. 0 processo recebeu o nome com referência ao seu criador, Louis-Jacques Mande Daguerre, o qual teria aperfeiçoado os procedimentos anotados por Joseph-Nicephore Niépce, desenvolvidos desde 1826 (data desse período aquela que é considerada a primeira imagem fotográfica - a vista da janela de seu estúdio -, mas que em função do tempo de exposição de várias horas não figurou como um processo fotográfico viável comercialmente). Ainda que os dois tenham assinado um acordo de trabalho em 1829, Niépce faleceu em 1833, cabendo a Daguerre dar continuidade ao desenvolvimento do processo. Os avanços foram consideráveis, sobretudo em relação ao tempo de exposição que passava de horas para períodos de quinze a sessenta minutos 3 .

0 daguerreótipo é o único processo na história da fotografia constituído inteiramente por metais. Trata-se de uma placa de cobre com uma superfície coberta por iodeto de prata que, após exposição à luz, é revelada por meio de vapores de mercúrio. A superfície que contém a imagem, por ser extremamente frágil, era protegida por uma placa de vidro, o que obrigava a apresentação do daguerreótipo em estojos. A imagem era única e não se podia reproduzi-la.

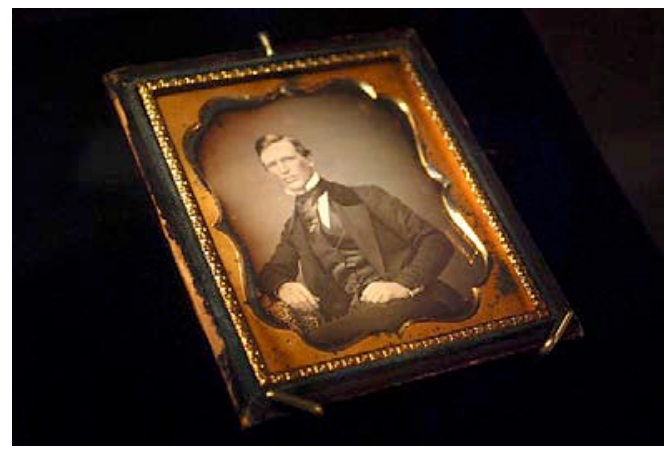

Fig. 1: retrato realizado com daguerreotipia (fotógrafo anônimo). Foto: Wagner Souza e Silva

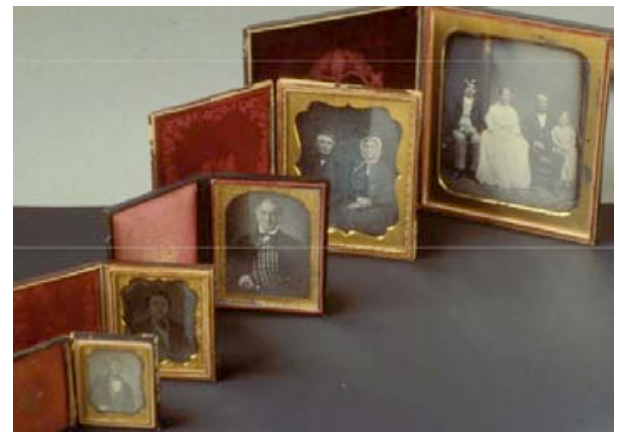

Fig. 2: Conjunto de estojos de daguerreótipos. Foto: Luis Pavão.

Foi Henry Fox Talbot quem introduziu a possibilidade de reprodução fotográfica com 0 calótipo, ou talbótipo, nos anos de 1840 e 1841 (apesar de já trabalhar com o sistema desde 1837, Talbot comunicou seu invento somente após tomar conhecimento da publicação de Daguerre $\left.{ }^{4}\right)$.

0 processo utilizava papel como negativo e como cópia, a despeito de apresentar a vantagem de ser menos frágil que o daguerreótipo, os traços da imagem no calótipo não

\footnotetext{
${ }^{3}$ THOMPSON, Nicola (org.). Tecnicas de los grandes fotografos. Madrid: Hermman Blue Ediciones, 1981, pp. 8-9.

${ }^{4}$ ROSENBLUM, Naomi. A world history of photography. New York: Abbeville Press, 2007, p. 29.
} 
obtinham a mesma definição que era possível no processo de Daguerre, basicamente pela interferência da densidade e textura fibrosa do papel. No entanto, tal comportamento plástico garantiu um caráter artístico ao processo de Talbot, e seria "frequentemente contraposto à secura documental do daguerreótipo". 5

Não obstante ter Talbot introduzido a possibilidade da reprodutibilidade ${ }^{6}$, foi com a utilização do vidro como suporte da matriz da imagem fotográfica que o procedimento foi aprimorado, e se começava a desenhar a prática fotográfica em larga escala. Com a introdução do processo do colódio úmido, os custos de produção das imagens fotográficas tornaram-se mais atrativos, o que provocou a queda vertiginosa de uso do daguerreótipo. Curiosamente, o ano de 1851, que marcou a introdução deste processo, com a publicação do Manual of Collodion Photographic Process, de Frederich Scott Archer, foi o mesmo ano da morte de Daguerre.

Helmut Gernsheim ${ }^{7}$ reconheceu tal processo como o responsável pela ascensão social da fotografia, e um dado de suas pesquisas pode ilustrar o impacto da era colódio (1850-1880): para o pesquisador, na Inglaterra de 1841 não havia registros da profissão de fotógrafo, mas em 1851 já havia 51 registros, e em 1861, 2.879 registros.

0 processo do colódio úmido utilizava placas de vidro que deveriam ser preparadas e reveladas num intervalo de quinze minutos, isto pelo fato de ter o éter, componente altamente volátil, como base na sua produção. Cabia ao fotógrafo, portanto, o domínio de todo 0 procedimento químico envolvido no processo.

Nas tomadas externas, em trabalhos de campo, os fotógrafos deveriam carregar não só suas pesadas câmeras e tripés, como também todo o suporte para preparação e revelação das chapas, um verdadeiro laboratório ambulante com produtos químicos, tenda para isolamento da luz, recipientes de cristal, e até uma porção de água no caso de ausência deste líquido no local do trabalho. ${ }^{8}$

\footnotetext{
${ }^{5}$ AMAR, Jean-Pierre. Op. cit., p. 26.

${ }^{6}$ Segundo Ricardo Mendes, "o processo do calótipo não estava ajustado no momento para a reprodução em escala. Com a produção dos positivos, o negativo em papel logo apresentava um esmaecimento, requerendo um tratamento para reforço. No entanto, este gerava um tom amarelado que dificultava a obtenção de cópias ". In: FABRIS, A. (org.). Fotografia: usos e funções no século XIX. São Paulo, Edusp, 2008. p. 104.

${ }^{7}$ GERNSHEIM, H. The rise of photography: 1850-1880 - The Age of Collodion. New York: Thames \& Hudson, 1988. Helmut Gernsheim (1913-1969) foi dos maiores investigadores e colecionadores de fotografia (descobriu, em 1956, a imagem da vista da janela de Niépce), e junto com Beaumont Newhall, figura com um dos mais influentes na definição do que é a história da fotografia. Vale dizer que Joan Fontcuberta aponta essa centralização como problema central em seu livro "Fotografia: crisis de historia", sobretudo em relação a Newhall. Questiona ainda se aquilo que chamamos de história da fotografia não teria sido apenas arqueologia da fotografia.

${ }^{8}$ THOMPSON, Nicola. Op. cit., pp. 12-13.
} 


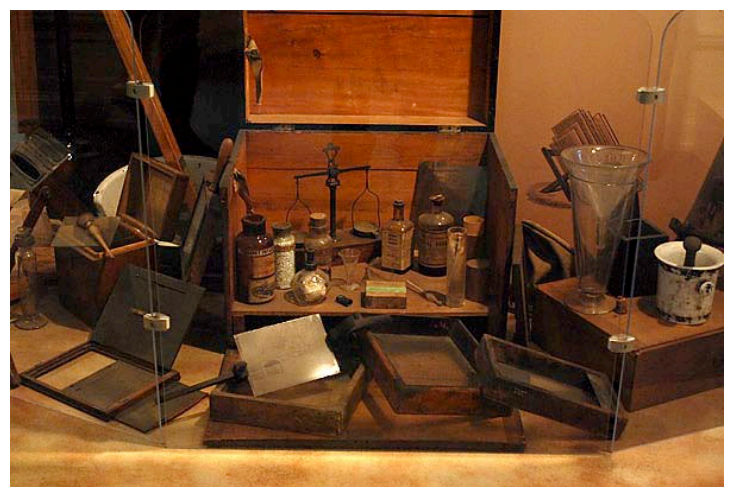

Fig. 3.: equipamento necessário para produção de chapas em colódio úmido. A imagem foi realizada na George Eastman House em Rochester, e corresponde ao conjunto adquirido pelo próprio George Eastman em 1877. Conta-se que esta parafernália foi decisiva para motivar Eastman na busca por procedimentos mais simples na obtenção de fotografias. Foto: Wagner Souza e Silva.

A substituição do colódio úmido como meio ligante dos sais de prata se deu com a introdução da gelatina em 1871. Introduzido por Richard Maddox, o uso da gelatina foi aperfeiçoado, o que permitiu, já ao final da década de 1870, a produção de chapas fotográficas "secas" e em escala industrial. Acabavam, assim, as incoveniências da necessidade do imediatismo da preparação e revelação que eram inerentes ao processo "úmido" de Sott Archer ${ }^{9}$.

Por fim, o último grande salto tecnológico do suporte fotográfico nessa fase inicial, e que passaria a sustentar a prática da fotografia ao longo do século XX, foi a substituição do vidro pelo celuloide. A junção da gelatina seca com as vantagens que o celuloide traria, primordialmente em relação à flexibilidade, transparência e peso, foi o que propulsionou a fotografia como prática cultural, universal e acessível, dadas as possibilidades de exploração comercial que essa nova estrutura permitiria.

Mas tal transição tecnológica do suporte, que passaria a ser definitiva ${ }^{10}$ naquele momento e que permeou quase todo o século XX, revelou uma nova escalada: definido o suporte, a incrementação da prática fotográfica se daria pela incrementação da tecnologia da máquina.

As câmeras fotográficas, sobretudo com relação aos sistemas das objetivas, já vinham sendo aprimoradas desde o surgimento do daguerreótipo. Em 1840, por exemplo, já se comercializavam objetivas dezesseis vezes mais claras do que aquelas introduzidas por Daguerre $^{11}$. Contudo, as vantagens da película fotográfica como matriz trariam alterações mais

\footnotetext{
${ }^{9}$ AMAR, Jean-Pierre. Op. cit., p. 31.

${ }^{10}$ Cabe apontar que se tratava de composto de nitrato de celulose que, devido ao fato de ser altamente inflamável, foi substituído a partir da década de 1950 pelo triacetato de celulose. É um importante dado técnico, mas que não influenciou, de forma significativa, o caminhar da prática fotográfica, revelando-se, na verdade, como um problema para os arquivos fotográficos de hoje.

${ }^{11}$ Desenvolvida por Friedrich Voitglander e Jsef Max Petzval (idem, p. 24).
} 
drásticas ao mercado de consumo, exigindo maior variabilidade de aparatos, com vistas justamente a atender uma demanda inédita no universo fotográfico que passaria a surgir.

Sem dúvida, foi George Eastman quem mais enxergou essa dialética entre suporte da imagem e tecnologia da câmera, como a própria definição do que seria o consumo de uma tal prática cultural da fotografia. Inventor da Kodak, nome que, conforme revela o web site da empresa $^{12}$, foi escolhido por ser pronunciado da mesma forma em qualquer lugar do mundo, Eastman lançou, em 1888, a sua primeira câmera, a Kodak $n^{0} 1$, já utilizando a tecnologia da gelatina seca. Permitindo ao seu usuário a produção de 100 imagens, as quais seriam processadas pelo fabricante, o lançamento teve como slogan a já célebre sentença: "Você aperta o botão e nós fazemos o resto." Vale apontar que o foco de interesse de Eastman, desde o início, concentrava-se na busca por uma alternativa ao pouco prático processo do colódio úmido e ao vidro como suporte. Desenvolveu seu próprio processo de gelatina e, para garantir a otimização da prática, introduziu a idéia do filme em rolo (primeiramente em papel), que chegaria ao mercado em 1889. Ideia que foi essencial a fim de que Thomas Edison desenvolvesse o rolo de película perfurada e a câmera cinematográfica. Já em 1896, a Kodak passaria a comercializar a película cinematográfica, tornando-se, até os dias de hoje, a principal fornecedora de material fotossensível para a indústria do cinema (todos os "melhores filmes", assim premiados pela academia de Hollywood, usaram película Kodak) e microfilmagem. Eastman sempre buscou 0 mercado de massas, a popularização do processo fotográfico, a possibilidade de tornar a fotografia "tão conveniente quanto um lápis" - tal como ele teria afirmado -, e a tecnologia simples de suas câmeras buscavam, nesse início, corresponder a tais objetivos. A câmera Brownie, por exemplo, de 1900, era vendida por US\$1.

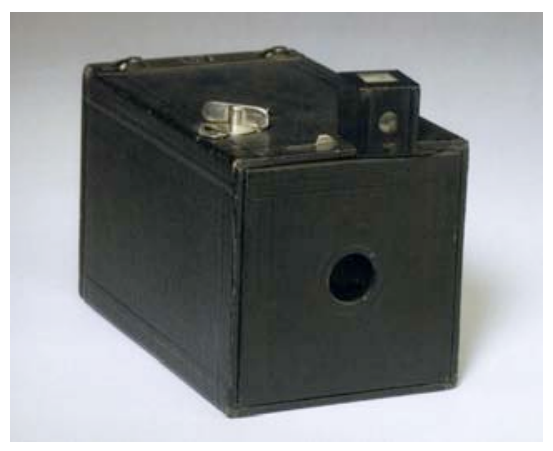

Fig4. : câmera Brownie da Kodak (1901), que pertenceu a Ansel Adams em sua infância. Foto de Barbara Puorro Galasso. In: GUSTAVSON, Todd. Camera: a history of photography from daguerreotype to digital. New York: Sterling, 2009, p. 9.

\footnotetext{
${ }^{12}$ Essas informaç̃es foram obtidas tanto no web site da companhia, quanto por anotações na exposição permanente da George Eastman House, durante a viagem de campo já relatada. Disponível em: $<\underline{\text { www.kodak.com.br }}$. Acesso em setembro de 2009.
} 
0 pequeno formato ganhou significativo incremento em 1925, quando surgiu a Leica, a primeira câmera do mercado para operar com películas perfuradas com fotogramas no tamanho de $24 \mathrm{~mm} \times 36 \mathrm{~mm}$ (duas vezes maior que o fotograma cinematográfico). Com a possibilidade de intercambiamento de objetivas, passaria a definir um mercado de equipamento portátil mais seleto, mais custoso ao consumidor comum, e que determinaria parâmetros tecnológicos que dariam toda a sustentação da prática do fotojornalismo, a "grande escola fotográfica do século" (tema a ser discutido mais à frente). Com a introdução da Leica no mercado e suas reverberações futuras (surgimento da Nikon e Canon, em especial), começava a surgir, como opção para 0 profissional, que até então utilizava câmeras de porte considerável para películas de $4 \times 5$ polegadas (sobretudo as Linhof e a Speed Graphic), um equipamento portátil mais enobrecido do que os disponíveis para o mercado doméstico da fotografia. Deve-se notar que a película de 35mm era acessível tanto ao "fotógrafo de família" quanto ao profissional, e mesmo que tenham existido películas também mais enobrecidas para o ramo profissional, pode-se dizer que a máquina fotográfica era o que melhor simbolizava tal distinção.

Seja pelo ineditismo em utilizar a película no formato $35 \mathrm{~mm}$ para a fotografia, seja pela qualidade óptica de suas imagens, as câmeras Leica tornaram-se verdadeiros mitos no universo fotográfico profissional. Até hoje, fotógrafos renomados, como Sebastião Salgado, Robert Capa ou Henri Cartier-Bresson têm seus trabalhos associados à esfera mítica de uma Leica ${ }^{13}$. Surgiu, assim, um nicho da tecnologia fotográfica inédito até então: câmeras portáteis com atributos suficientes para se destacarem daquele universo doméstico que se desenhava pelas mãos de George Eastman.

Entre outras fabricantes, a Nikon e a Canon se destacam como componentes fundamentais do consumo fotográfico deste nicho. A primeira, inicialmente disponibilizando apenas objetivas desde 1930, passaria a entrar definitivamente neste mercado em 1959, com o lançamento da câmera Nikon $\mathrm{F}^{14}$; já a Canon, buscando uma alternativa tecnológica menos onerosa do que a imposta pela Leica, lançou sua primeira câmera de objetivas intercambiáveis em 1935, a Hansa Canon. Foram passos iniciais daquelas que passariam a ser as duas maiores fornecedoras de equipamento digital para os fotojornalistas de todo o mundo.

\footnotetext{
${ }^{13} 0$ emblemático retrato de Che Guevara, realizado por Alberto Diaz Gutierrez (o "Korda"), foi também produzido por uma Leica. Alessandro Pasi, em Leica: witness to a century (2003), explora esta esfera mítica do equipamento.

${ }^{14}$ Cabe dizer que outras câmeras Nikon teriam sido lançadas anteriormente, como em 1947 (Nikon I) e 1954 (Nikon S), também com objetivas intercambiáveis. A razão por apontar a Nikon $\mathrm{F}$ como marco reside na sua onipresença, que passaria a permear a prática do fotojornalismo na década de 60 (GUSTAVSON, op.cit., p. 312).
} 
A fotografia passou a ter, desta forma, e ao longo do século XX, três grandes grupos de equipamento, com estruturas distintas a partir do tamanho de suas superfícies fotossensíveis: 0 grande formato, o médio formato, e o pequeno formato. 0 porte das câmeras seria proporcional ao tamanho das películas ${ }^{15}$.

As câmeras de grande formato seriam aquelas com matrizes a partir de $4 \times 5$ polegadas $(9 \times 12 \mathrm{~cm})$, e se aproximariam do aparato que reinou ao longo do século XIX, que também produzia chapas. Foram muito utilizadas na publicidade e nas artes plásticas quando a nitidez e a qualidade da imagem eram necessárias, mas não tinham a agilidade dos aparatos de porte menor. As câmeras de médio formato, já bem menores do que as de grande formato, também se destacavam no quesito "qualidade e nitidez", e do mesmo modo encontravam seu nicho de uso na publicidade e nas artes. Também estas câmeras seriam utilizadas na prática doméstica, principalmente após relativa popularização (eram e são bem mais custosas que as câmeras de $35 \mathrm{~mm}$ ) dos equipamentos Hasselblad, introduzidos em 1948, responsáveis pelas tomadas fotográficas em solo lunar em 1969, e as Rolleiflex em 1929, sendo estas de uso bem mais comum. Ao trazerem matrizes de $6 \times 4,5 \mathrm{~cm}, 6 \times 6 \mathrm{~cm}, 6 \times 7 \mathrm{~cm}$, e $6 \times 9 \mathrm{~cm}$, ou seja, até quatro vezes maiores do que o fotograma da película de $35 \mathrm{~mm}$, tais sistemas permitiam aliar agilidade e qualidade.

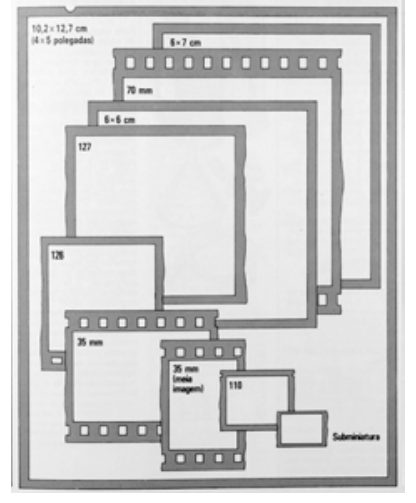

Fig. 5: a variabilidade de tamanhos de suportes em película. Fonte: HEDGECOE, op. cit., p. 45

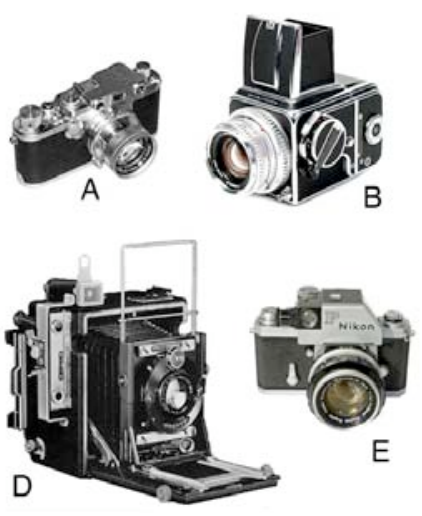

Fig.6: A - Leica (1925); B - Hasselblad (1948); D - Speed Graphic (1940); E - Nikon F (1959).

\footnotetext{
${ }^{15}$ Existe aqui uma certa preocupação em insistir na descrição das estruturas tecnológicas da câmera e do suporte da imagem matriz apenas (já descrito neste trabalho pelo conjunto do daguerreótipo, calótipo, negativo de vidro de colódio úmido e película com gelatina), pois entende-se que estes determinam o universo ainda da prática do registro numa relação mais básica. Reconhece-se a riqueza e a evolução envolvida também nos processos de produção das cópias, ou seja, da fotografia em papel, desde o calótipo e o colódio úmido, bem como da introdução da cor nas matrizes (dos Autochromes dos irmão Lumiére em 1908, e os Kodachromes de 1935), mas tais apontamentos não são aqui considerados imprescindíveis para a abordagem da técnica fotográfica na sua natureza mais essencial de operação.
} 
Mas a prática por meio destes dois sistemas não pode ser comparada à desmesura do pequeno formato, com os dois eixos de popularização de sua estrutura tecnológica. 0 pequeno formato para o consumo doméstico trazia câmeras mais leves, automáticas, e qualidade óptica questionável (principalmente quando usavam acrílicos ao invés de vidros como lentes nas objetivas) e, por isso, era um sistema menos oneroso; o destinado ao profissional trazia versatilidade de uso (troca de objetivas, uso de motores mais ágeis de avanço da película, etc.), robustez e qualidade óptica superior (priorizava o uso do vidro) e, por isso, eram bem mais custosos e exigiam de seu usuário um envolvimento com a prática numa outra ordem. As reverberações deste sistema no entendimento do que é a fotografia como prática de imagem, assim como a influência dos outros formatos apontados, serão exploradas no próximo capítulo.

Enfim, cabe ainda apontar dois momentos que buscaram reforçar a evolução tecnológica num sentido evidentemente concentrado na simplificação dos procedimentos de obtenção da imagem fotográfica: a Polaroid (1948) e o sistema APS (Advanced Photo System), em 1996.

A introdução da Polaroid deve ser pontuada por ser evidência de que a instantaneidade da imagem fotográfica sempre foi desejada. Sua prática foi sucesso até o advento das câmeras digitais (a empresa fechou as portas em 2008), mesmo com sua imagem de qualidade bem inferior às películas de $35 \mathrm{~mm}$. Aqui teríamos um sintoma, portanto, de que a necessidade de uma boa imagem não era tão maior do que a necessidade de se ter imediatamente a imagem. Outro fator que a colocava em paralelo com os dias de hoje, era a descartabilidade de suas fotografias, pois as cores logo se perdiam em função de sua estrutura, que não permitia dispensar os químicos de revelação, e estes permaneciam na folha da imagem (não se podia lavar os polaroids e assim estabilizar a imagem).

Já o sistema APS envolvia a substituição de toda a base instalada. Contou com um joint venture de empresas, entre elas a Kodak e a Fujifilm no setor de películas e câmeras, e a Nikon e a Canon no setor de câmeras. Tratava-se de uma película que trazia uma banda magnética que gravava informações geradas pela câmera, específica do sistema, e serviriam de referência para os processos de revelação e ampliação em laboratório. Curioso observar que foi um último suspiro para a tentativa de se garantir um mercado já consagrado de filmes diante das novas tecnologias que surgiam. 0 objetivo era claro: automatizar ainda mais o equipamento e diminuir ainda mais a necessidade de domínio técnico do usuário. Porém, não resistiu ao crescente avanço 
das câmeras digitais compactas, sendo que em 2004 a Kodak deixaria de fabricar filmes e câmeras do sistema.

$\mathrm{Na}$ trajetória da tecnologia da fotografia, até antes de sua inserção no digital, pode-se perceber este movimento que é evidente: do metal passou-se ao papel, do papel passou-se ao vidro, do vidro passou-se ao plástico; e em relação ao seu maquinário, passou-se do grande ao portátil. A fotografia foi sendo enraizada socialmente pela perda significativa de sua matéria tecnológica, e isto se acentua na era digital (o que será abordado na segunda parte da tese). Mas antes, cabe revisar os reflexos desta tecnologia do século XX na acepção social da fotografia, tarefa para o próximo capítulo. 


\section{DETERMINAÇÃO SOCIAL DE UMA PRÁTICA DE IMAGENS}

A história da fotografia, mesmo com suas indefinições e suspeitas quanto à data de seu surgimento, já possui dados suficientes desmembrados em obras significativas que dão conta de sua constituição. Malgrado se questione o totalitarismo dos pontos de vistas europeu e norteamericano nessa trajetória da fotografia e, vale a pena ressaltar, Hercules Florence no Brasil é um forte indício desse questionamento ${ }^{1}$ (mesmo sendo europeu), a história da tecnologia da fotografia já está devidamente documentada e parece não haver mais espaço para buscas e descobertas de dados empíricos que possam revolucionar de maneira significativa este caminhar tecnológico e cultural da fotografia. 0 que parece ser possível é destacar alguns destes dados, isolá-los, visando a estabelecer variações de conexões de forma a incrementar um ou outro aspecto de significação cultural da prática, ainda que uma forma de abordagem nesse sentido possa trazer simplificações ou reduções consideráveis, como até ocorreu no capítulo anterior; ou seja, optar por pontuações específicas dessa trajetória parece ser também uma forma de salientar aspectos universais refletidos pela tecnologia da fotografia.

\footnotetext{
${ }^{1}$ Impossivel deixar de citar o trabalho de Boris Kossoy nesse sentido. Sua obra Hercules Florence: a descoberta isolada da fotografia no Brasil. (Edusp, 2006) é referência para esse tipo de questionamento. Kossoy também discorre sobre esse totalitarismo e sobre o impacto de suas pesquisas na obra "Fotografia: crisis de historia", organizada por Joan Fontcuberta (2003).
} 
Cada tecnologia foi utilizada dentro de uma perspectiva própria, e assim coube à fotografia determinar a práxis da imagem. Dos retratos posados na daguerreotipia ao "instante decisivo"2 no fotojornalismo, passando pelo uso nas ciências e nas artes, a tecnologia foi sendo crescentemente enraizada, instituindo não só um novo hábito de imagens, mas também rituais sociais que passaram a encontrar na fotografia um reforço para a sua significação.

É essa dimensão do papel social da fotografia que permite a Jean-Claude Lemagny afirmar que a "história da fotografia" tenha sido até agora quase o mesmo que a "história através da fotografia"3. Assertiva que denuncia a onipresença da tecnologia, do mecanismo que atua em função de uma precisão na representação e que dá à fotografia todo o seu caráter objetivo e documental. É como se o seu primeiro anúncio realizado na Academia de Ciências de Paris ${ }^{4}$ tivesse predestinado o seu caráter mais fundamental, onde a "dureza" das ciências que a estruturam reverberasse na composição de sua essência.

0 fato é que a tecnologia da fotografia, respaldada por sua ciência intrínseca, adentrou em diversas esferas sociais. Neste processo de ascensão social paralelo à ascensão tecnológica, a fotografia tornou-se uma prática atuante em postos extremos: ao mesmo tempo que era um instrumento de pesquisa de grande credibilidade, ela ainda servia aos propósitos mais triviais em meio ao cotidiano banal da sociedade moderna, como se pode constatar em qualquer álbum de família; ao mesmo tempo que documentava e atestava fatos notáveis da história mundial no universo fotojornalístico, também garantia espaço para situar-se na dinâmica de produção das obras de arte. Jean-Marie Schaeffer observa:

0 aspecto mais irritante, mas também o mais estimulante, do signo fotográfico reside, sem dúvida, em sua flexibilidade pragmática. Todos sabemos que a imagem fotográfica é colocada a serviço das mais diversas estratégias de comunicação. ${ }^{5}$

Tal flexibilidade pragmática torna-se importante componente para reforçar a ideia de que a fotografia foi muito mais assimilada como instrumento, uma ferramenta: enfim, um dispositivo

\footnotetext{
${ }^{2}$ CARTIER-BRESSON. El instante decisivo. In: Fotografiar del natural. Barcelona: Gustavo Gili, 2003, pp 11-35.

${ }^{3}$ LEMAGNY apud FONTCUBERTA, Joan (org.), op. cit., p. 8.

${ }^{4}$ Referência à primeira comunicação de François Arago, em janeiro de 1839. Neste momento, o processo do daguerreótipo ainda não tinha sido revelado e se tornado público, coisa que só ocorreu em 19 de agosto do mesmo ano, data que é o marco do surgimento da fotografia. AMAR, op. cit., p. 20.

${ }^{5}$ SCHAEFFER, Jean-Marie. A imagem precária. São Paulo: Papirus,1996, p. 10.
} 
destinado a múltiplos usos e que visavam a múltiplos objetivos. Nessa multiplicidade de usos, aquilo que poderia corresponder propriamente a uma identidade da técnica fotográfica pode ter se diluído em seu caráter pragmático.

Uma vez destacados o straight photography e o pictorialismo, como evidências de uma oscilação que parece ser a base sustentadora das questões que envolvem a fotografia como arte, -o que não deixa de ser também a exploração de um aspecto desse pragmatismo-, cabe agora destacar outros dois fortes componentes desse conjunto pragmático: a fotografia de família e 0 fotojornalismo. 0 significado social da prática ganha mais evidência com estes dois novos vetores de análise, até porque os álbuns de família e as páginas de jornais e revistas formam o grosso daquilo que permite Lemagny afirmar a "história-através-da-fotografia". Ao mesmo tempo, conforme já apontado, tais vetores operaram com o mesmo formato de filme, e são emblemáticos no sentido de permitir o entendimento do mito, que é a ideia de uma "boa fotografia" fundamentada pela tecnologia, pois os parques tecnológicos destes dois nichos da prática são bastante próximos estruturalmente, uma vez que ambos operam com câmeras de pequeno formato.

Apesar de constatar que, entre o daguerreótipo (1839) e o surgimento do celuloide como suporte (1887), houve saltos tecnológicos consideráveis na estruturação da tecnologia da fotografia, para otimizar esta breve reflexão, torna-se oportuno considerar como ponto de partida a virada do século, mais precisamente o ano de 1900, com o lançamento da Brownie, da Kodak. Ainda que este tipo de equipamento não utilize a película de $35 \mathrm{~mm}$, sua portabilidade já começava a definir uma certa tensão entre fotógrafos de família e profissionais em função do despojamento que passava a surgir com esse tipo de tecnologia. É Marien quem sustenta:

Em 1900, a compania lançou a câmera Brownie, que foi direcionada inicialmente para o público infantil. Embora os instantâneos retratassem, na sua maioria, a vida privada, eles tiveram um impacto significativo. Não só reduziram 0 número de retratistas profissionais, como também promoveram a associação entre verdade fotográfica e informalidade. Cada vez mais fotojornalistas passariam a usar o despojamento do instantâneo...6

\footnotetext{
${ }^{6}$ Tradução livre do original: "in 1900, the company lauched the inexpensive "Brownie" camera, which is marketed initially to children. Though snapshots were mostly personal pictures, they did have a significant impact. Not only did snapshots reduce the number of professional portrait photographers, they also deepened the association between informality and photographic truth. Increasingly press photographers emulated the casual look of the snapshot (...)". In: MARIEN, Mary Warner. Photography: a cultural history. New York: Harry N. Abrams, 2002, pp 169-170.
} 
No caso das fotografias de família, por ser uma prática que está ao alcance de todos, não será preciso deter-se de forma demasiada em seus aspectos descritivos. Viajar e fotografar, festejar e fotografar, ser fotografado ou empunhar uma câmera fotográfica, é algo que acontece de forma corriqueira na vida familiar. A partir da Brownie, fotografar tornava-se brincadeira de criança. A fotografia se dava aqui numa relação afetiva com a tecnologia, considerando os desejos e as motivações que a exigiam como cúmplice. A câmera era instrumento para preservar o mundo particular de cada um, coisa que se pode constatar em qualquer álbum de família. É certo que uma padronização do olhar começava a se desenhar (Flusser denominaria isso como o fotografável, o que será discutido nos próximos capítulos), mas cabe, por enquanto, apenas destacar que dada essa relação mais afetiva com a tecnologia, não havia, para esse nicho, a necessidade de câmeras mais robustas ou tecnológicamente mais elaboradas, bem como não havia a priorização da qualidade técnica para atingir os objetivos pretendidos. 0 sucesso da Polaroid, por exemplo, se deveu a essa postura. Poder-se-ia destacar desse nicho os "amadores", estes que buscavam ir além de um uso mais despojado, e assim adquiriam material equiparado aos profissionais. Entretanto, dessa maneira, eles estariam não mais dentro de uma relação afetiva, e sim caminhando em direção a uma relação aflitiva.

A aflição pode ser considerada o estado de consciência que circunda a relação do fotojornalista com tecnologia fotográfica (e que até poderia ser estendida a todos os profissionais). Devido à necessidade de agilidade e de versatilidade, era inadmissível para os fotógrafos buscarem seus instrumentos no mesmo parque tecnológico da prática doméstica. Nesse sentido, parece até sintomático o fato de a ascensão do fotojornalismo ter-se dado junto a uma causa aflita por natureza: as guerras. ${ }^{7}$

As principais guerras do século XIX que foram documentadas fotograficamente, a saber, a Guerra da Crimeia (1853-1856), fotografada principalmente por Roger Fenton, e a Guerra da Secessão nos EUA (1861-!865), documentada por Mathew Brady e sua equipe, ainda teriam 0 colódio úmido como tecnologia fotográfica ${ }^{8}$. Vale lembrar da pouca agilidade que o processo oferecia, e isto inevitavelmente surgia como empecilho para o registro das batalhas ou de qualquer outro tipo de ação. Os registros dessas guerras só puderam mostrar o antes e o depois de cada batalha.

\footnotetext{
${ }^{7}$ Necessário apontar o trabalho desenvolvido por Vanessa Corrêa da Silva (2009), no departamento de jornalismo da ECA/USP, em que explora o tema das fotografias de guerra, servindo aqui como importante fonte de dados para argumentação.

${ }^{8}$ Idem, pp. 10-12.
} 
Com o surgimento da Leica em 1925, e as futuras câmeras de pequeno formato equivalentes, tais conflitos passariam a ser fotografados dentro de uma dinâmica inédita. Quem pode melhor representar tal perspectiva é Robert Capa, que teria realizado a primeira investida com esse tipo de equipamento, o que se deu na Guerra Civil Espanhola (1936-1939), de onde se extrai a já mais do que emblemática fotografia do soldado tombando após ser alvejado.

As guerras foram as incitadoras de uma prática fotográfica que buscava atender à tensão e ao movimento caótico dos conflitos e de seus reflexos. Para os fotojornalistas, seria fundamental um equipamento que pudesse atender ao controle da luz dentro de uma agilidade ímpar, pois a perspectiva de trabalho imersa numa ambiência frenética seria quase sempre inevitável: os motivos, na maioria das vezes, dificilmente "paravam" e "posavam" para a foto, tal como na fotografia familiar.

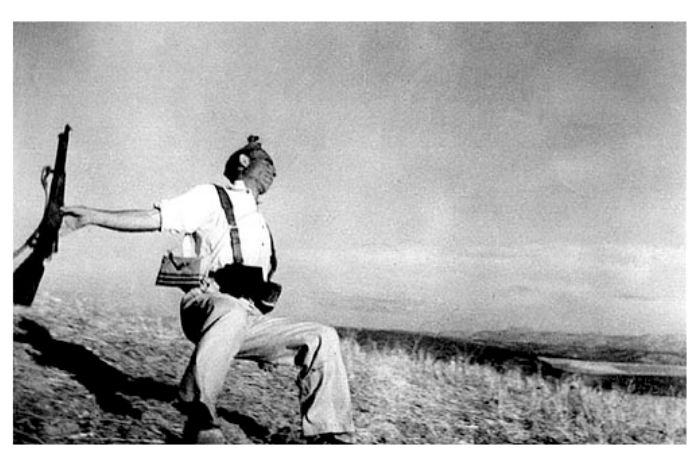

Fig. 7: Fotograffia de Robert Capa.

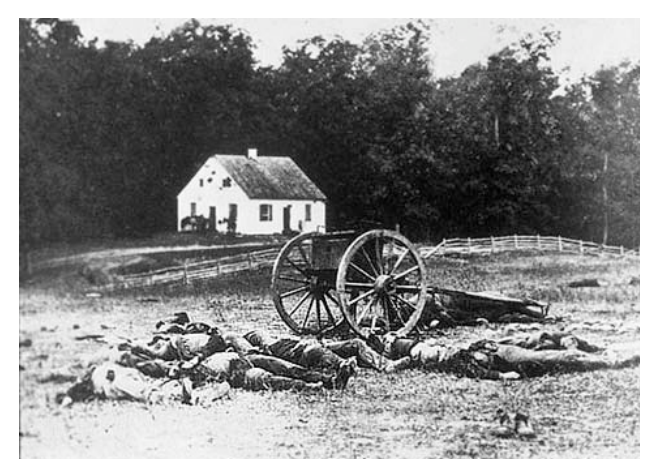

Fig 8: Fotografia de Mathew Brady.

0 fotojornalismo evidencia a presença humana do fotógrafo na composição das imagens, e tal constatação ganha contornos mais expressivos nas imagens de guerra. 0 clima de agilidade e versatilidade exigido pelo fotojornalismo parece ter sido determinante na definição do meio profissional-fotográfico, entendido como um modelo que aliava sensibilidade do autor ao domínio técnico de seu equipamento (outras atuaç̃̃es profissionais com a fotografia seriam mais definidas como meras "reproduções técnicas", tanto para o senso comum quanto para os próprios fotojornalistas).

As revistas de grande circulação na época (períodos entreguerras e pós-Segunda Guerra), só para apontar as mais expressivas, Vu e Regards (França), Times (EUA), Picture Post 
(Inglaterra), Cruzeiro (Brasil) e Berliner Illustrierte Zeitung (Alemanha) ${ }^{9}$, destinavam espaço especial ao fotojornalismo, prática que passaria a ser, para muitos, sinônimo de fotografia profissional.

Tem-se, como exemplo, para fundamentar tal assertiva, o World Press Photo, prêmio mais reconhecido de "melhor fotografia do ano", e que normalmente é assim anunciado aos quatro cantos do mundo. Ora, não se trata de melhor fotografia do ano, mas como o nome do prêmio denota, trata-se da melhor fotografia jornalística do ano. E observando as melhores fotografias desde 1955, ano inicial da premiação, vê-se que todas as imagens retratam guerras, conflitos e tensões, o que só reforça o paralelo proposto no exame da ascensão do fotojornalismo ${ }^{10}$.
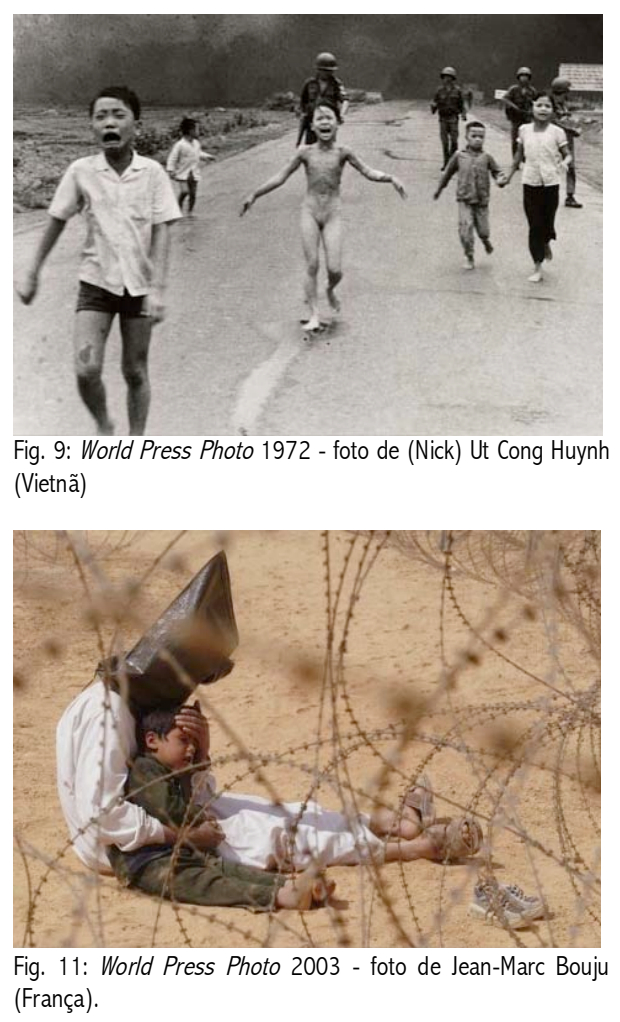
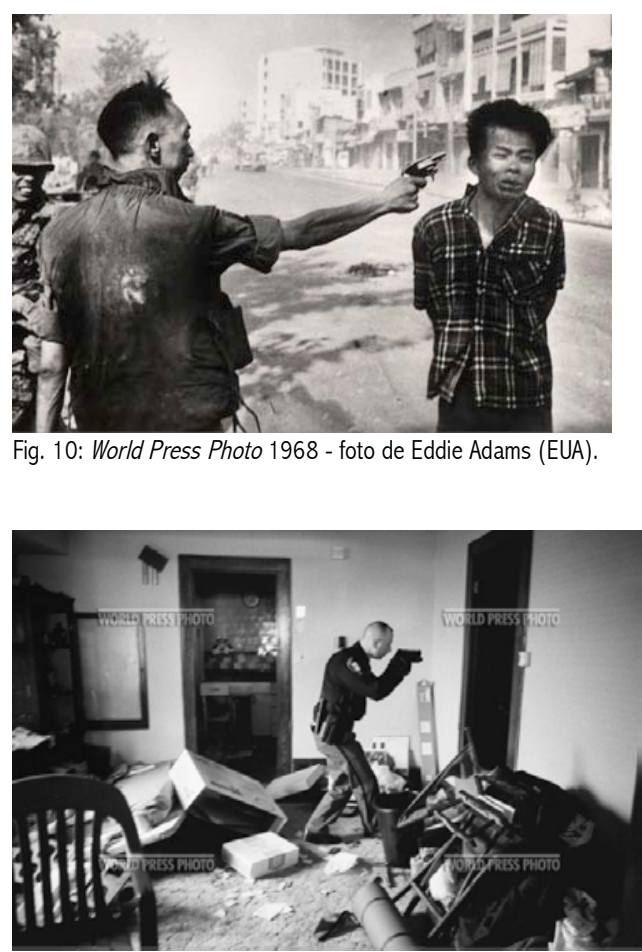

Fig. 12: World Press Photo 2008 - foto de Anthony Suau (EUA).

Neste momento, pode-se até voltar aos outros formatos a fim de examinar a relação entre fotógrafo e tecnologia nos âmbitos da aflição e afeição. A câmera 4×5, por exemplo, exige a necessidade do cumprimento de etapas dentro de uma agilidade que seria impossível ao

\footnotetext{
${ }^{9}$ Idem, p. 48.

${ }^{10}$ Disponível em http://www.archive.worldpressphoto.org/years. Acesso em fevereiro de 2009.
} 
fotojornalismo, a saber, enquadramento, foco manual, fechar a objetiva, carregar a câmera com um chassis com uma chapa de filme, retirar a proteção do filme e disparar o obturador: por mais rápido que fosse, 0 intervalo entre 0 enquadramento e o disparo do obturador de uma câmera desse tipo levaria, no mínimo, mais do que 20 ou 30 segundos, tempo imensamente maior do que os centésimos de segundo da fotografia flagrante ${ }^{11}$. A afeição pode até surgir nessa perspectiva de uso mais elaborada, mas a aflição espreita quando se nota, por exemplo, a necessidade de uma objetiva de qualidade óptica superior para atender às exigências de um anúncio publicitário ou à reprodução fotográfica de uma obra de arte num museu. 0 mesmo vale para o médio formato: não exige as mesmas etapas do $4 \times 5$, pode ser tão ágil quanto o pequeno formato, mas também se restringe aos profissionais e amadores que, conforme se supõe aqui, estariam nesse clima de aflição.

Não se pode afirmar, porém, que os profissionais não tenham nunca uma relação afetiva com a tecnologia da fotografia, afinal são eles também pertencentes a uma família. Mas pode ser curioso constatar que tal relação não se dá, muitas vezes, com a mesma ferramenta de trabalho. É bastante comum aos fotógrafos profissionais possuírem ainda um equipamento mais despojado para essa prática de fotografia mais espontânea em seus círculos sociais mais íntimos. Mesmo que possa ser igualmente uma opção que vise a preservar seu equipamento de trabalho, não deixa de reforçar a distinção entre as perspectivas de uso dos dois vetores de tecnologia.

Enfim, a atuação fotográfica profissional tende a se delinear numa relação mais aflitiva com a tecnologia, onde o domínio da laboriosidade da práxis torna-se fundamental para garantir os objetivos de qualquer atuação neste sentido. E desta forma, os contextos que significativamente determinaram a referência do que seria uma "boa fotografia", se deram numa perspectiva menos afetiva com a práxis, mais por embates e batalhas: a primeira, num nível mais conceitual, se deu com a arte; a segunda, num nível mais pragmático, se deu com a própria tecnologia da fotografia, quando se constata que uma "fotografia séria", como sugere Ansel Adams $^{12}$, dependeria do domínio dos tecnicismos que circundavam as práticas profissionais.

\footnotetext{
${ }^{11}$ As câmeras 4×5 Speed Graphic e Linhoff, já apontadas, também foram utilizadas no fotojornalismo, mas mesmo assim exigiam 0 carregamento do chassis o que restringia, muitas vezes, a documentação do fato já ocorrido, valendo a pena aqui destacar Weege, célebre fotógrafo norte-americano, famoso por suas imagens de tragédias urbanas. Ver mais em THOMPSON, op. cti., pp. $112-$ 115.

${ }^{12}$ Adams não chega a usar o termo "fotografia séria", mas na introdução de seu manual diz esperar esta postura de seu leitor que pretenda realmente aprender sobre a tecnologia da fotografia: "it is assumed that the serious student will provide himself with adequate and dependable equipment". In: ADAMS, op. cit., p. 16.
} 
A determinação social de uma prática de imagens foi, em muitos aspectos, a determinação social de uma ferramenta tecnológica. Esta partilha entre o profissional e o nãoprofissional, entre uma imagem doméstica e uma imagem "séria" demonstra o reforço da esfera mítica ao redor do parque tecnológico dos profissionais.

Mas como bem afirma Todd Gustavson, "tecnologia é uma coisa, fotografia é outra", e a "câmera mais cara não pode fazer mais do que apenas contar uma história"13, o que leva a crer que qualquer forma de valoração da imagem instituída pela tecnologia se sustentará numa base extremamente frágil, pois qualquer estrutura fotográfica se define fundamentalmente pelos mesmos parâmetros. Essa fragilidade deve ser evidenciada se a intenção é investigar os traços mais elementares da prática: deve-se reunir essa fotografia que está partilhada e dispersa na sua flexibilidade pragmática, tarefa essa que se inicia a partir do próximo capítulo.

${ }^{13}$ GUSTAVSON, Todd. op. cit., p.8 


\section{A DIFICULDADE DOS GÊNEROS}

Quando se define um gênero fotográfico, atribui-se um lugar social para a fotografia. Tais gêneros são delineados levando-se em conta a esfera prática de atuação do fotógrafo e as informações do motivo fotografado. Mas considerando a flexibilidade pragmática da fotografia e sua inserção social em esferas múltiplas, podem-se ainda considerar os gêneros que the foram destinados desde o seu surgimento como um componente importante para a definição de seu estatuto? A tese, nesse momento, é que tais gêneros pareceram mais constribuir para o lugar das fotografias, do que da fotografia, sendo, portanto, reflexo direto da apropriação desta como mera ferramenta tecnológica.

Os gêneros consagrados foram herdados da pintura: retrato, paisagem, alegoria e natureza morta (still-life) ${ }^{1}$. Os gêneros desenvolvidos pela fotografia seriam aqueles determinados a partir de suas especificidades técnológicas, destacadamente aquelas correspondentes ao seu mecanismo de captura instantânea, aquele que permitiria atingir o "inconsciente óptico" da cena,

\footnotetext{
${ }^{1}$ FREITAS, Gabriela. A constituição dos gêneros fotográficos. Disponível em http://www.fotoclubef508.com/. Acesso em julho de 2009.
} 
como teria dito Walter Benjamin ${ }^{2}$. Soma-se a isso, a sua potência figurativa, a "plenitude analógica", como Barthes ${ }^{3}$ já afirmara noutro momento. Nasceu daí o fotojornalismo que é, na verdade, a fotografia estabelecida como documento, como prova de um acontecimento, quase sempre o registro de um instante flagrado. Tais mecanismos permitiriam também, na mesma linha documental, estabelecer a fotografia científica, que pode ser desmembrada nas mais diversas aplicações das mais diversas ciências: etnologia, antropologia, astronomia, zoologia, botânica, e que, nas experiências cronotópicas de Ettiene Jules-Marey e Eadweard Muybridge, encontraram indissociabilidade exemplar.

A fotografia de família, também já abordada, deve ser considerada um gênero que teria surgido a partir de tais mecanismos, pois estes estabeleceram a possibilidade do despojamento do snapshot ou do point\&shoot, fazendo da câmera fotográfica o "braço ideal da consciência" para a captura das experiências vividas. 0 cotidiano da vida doméstica e suas prática sociais, como viagens e festividades, passaram a contar com a parceria e a cumplicidade da fotografia.

Mas pode-se ter em mãos um fotografia de família classificada como científica, se usada num estudo antropológico, e que também poderia tornar-se documental quando impressa nas páginas dos jornais, assim como uma fotografia jornalística torna-se evidência científica quando traz precisão e a descoberta de alguma informação visual inédita. E todas poderiam estar expostas nas paredes de uma galeria de arte a partir do momento que trazem uma experiência estética que as justifiquem para tal uso, seja uma alegoria muito bem encenada, seja um still-life produzido para uma campanha publicitária ou para um artigo científico sobre rochas e minerais.

A agilidade, o instantâneo, a plenitude analógica, ou seja, os vetores dos mecanismos que permitiriam estabelecer gêneros fotográficos são os mesmos que acabam por confundi-los e misturá-los. Assim como na definição do que seria uma "boa" fotografia, vê-se também uma fragilidade incontornável na definição exata de um gênero fotográfico. A divisão já apontada na partilha tecnológica da fotografia (profissional e a não-profissional) se desmembra ainda mais na adequação das imagens em gêneros.

\footnotetext{
2 BENJAMIN, Walter. Pequena história da fotografia. In: Magia e técnica, arte e política: ensaios sobre literatura e história da cultura. São Paulo: Brasiliense, 1996, p. 94

${ }^{3}$ BARTHES, Roland. A mensagem fotográfica. In: O óbvio e o obtuso. Rio de Janeiro: Nova Fronteira, 1990, p. 14.

${ }^{4}$ SONTAG, Susan. Sobre Fotografia. São Paulo: Companhia das Letras, 2004, p 14.
} 
Recentemente foi disponibilizada, nas bancas de jornais brasileiras, uma coleção intitulada "Grandes fotógrafos", que trazia imagens de nomes consagrados da fotografia do século XX (e cabendo reforçar o capítulo anterior, vale dizer que as imagens eram, em sua maioria, fotojornalísticas). Mas ao contrário do que denota o título da coleção, os fascículos foram organizados por temas como "Metrópoles", "Guerras", "Esportes", "Crianças", etc. , e em cada um dos fascículos encontram-se indícios dos grandes gêneros citados. Mas não são estes que ganham evidência, nem são os fotógrafos que motivam a aquisição da coleção, mas sim o objeto representado, claramente definido como ponto de apoio para o fotográfico presente na coleção. Sintoma de um posicionamento comum em relação à fotografia: defini-la pelo que ela traz como representação.

Em resumo, levando-se ao extremo a busca por tais classificações na fotografia, os gêneros passariam a ser definidos pela mesma descrição do conteúdo das imagens. É com tal confusão que Barthes se depara em $A$ câmara clara, ao admitir que o surgimento da fotografia talvez tenha trazido algo de novo ao universo imagético, mas que, ao tentar constituir um corpus de estudo, ele tem de enfrentar a dificuldade de classificação. Vê que todas as divisões que a abarcam (empíricas, estéticas ou retóricas) poderiam também ser aplicadas em outras formas mais antigas de representação, fazendo-o concluir que a fotografia é inclassificável:

Desde o primeiro passo, o da classificação (é preciso classificar, realizar
amostragens, caso se queira constituir um corpus), a Fotografia se
esquiva. As divisões às quais ela é submetida são de fato ou empíricas
(profissionais/amadoras), ou retóricas (paisagens, objetos, retratos), ou
estéticas (realismo/pictorialismo), de qualquer modo exteriores ao objeto,
sem relação com sua essência, que só pode ser (caso exista) o Novo de
que ela foi o advento, pois essas classificações poderiam muito bem
aplicar-se a outras formas, antigas, de representação. Diríamos que a
fotografia é inclassificável. ${ }^{6}$

Essa confusão de gêneros, denunciada por Barthes, mostra a aproximação inicial com a pintura que se buscou logo no surgimento da fotografia. Uma clara tentativa de definir um lugar social para a prática, que confundiu seus propósitos com os mesmos propósitos da arte pictórica. Levando-se em conta que estes gêneros ainda estão presentes, pode-se supor mais um sintoma que corrobora a ideia, que aqui

\footnotetext{
${ }^{5}$ Folha de S. Paulo. Coleção Folha Grandes Fotógrafos. São Paulo: Editorial Sol90, 2009. Circulou entre janeiro e abril de 2009.

6 BARTHES, Roland. A câmara clara, op. cit., p.13.
} 
se busca desenvolver, de que a fotografia tenha sido praticada, até o final do século XX, tendo sempre a arte prictórica como referência e como pilar sustentador. Observe-se a passagem de Benjamin:

E, no entanto, foi com esse conceito fetichista de arte, fundamentalmente atitécnico, que se debateram os teóricos da fotografia durante quase cem anos, naturalmente sem chegar a qualquer resultado. Por que tentaram justificar a fotografia diante do mesmo tribunal que ela havia derrubado. Muito diferente é o tom com que o físico Arago defendeu a descoberta de Daguerre no dia 3 de julho de 1839, na Câmara dos Deputados. A beleza desse discurso vem do fato de que ele cobre todos os aspectos da vida humana. 0 panorama por ele esboçado é suficientemente amplo para tornar irrelevante a justificação da fotografia em face da pintura... ${ }^{7}$

"Cobrir todos os aspectos da vida": estaria aí uma correspondência para um possível grande gênero fotográfico?

Na ideia moderna de arte como "campo de criação e da expressão", a ciência não encontraria espaço por representar o "campo da técnica, do rigor metodológico e matemático", sendo que, desta forma, arte e ciência transitariam em "dimensões e bases teóricas completamente distintas" ${ }^{8}$. Mas a fotografia parece invadir ambos os campos e correlacioná-los em certos momentos: seria o "rigor metodológico e matemático da tecnologia da fotografia" encontrando forma de produção no "campo da criação e da expressão" atribuídos à arte. Ora, se é verdade que "as atividades relacionadas ao conhecimento humano giram em torno de um componente lógico, racional e inteligível, de um lado, e de um componente intuitivo e sensível, de outro"9 , a fotografia torna evidente a fragilidade e a linha tênue dessa partilha entre arte e ciência.

A fotografia traz, portanto, a equivalência e a possibilidade de complementaridade entre o conhecimento científico e artístico, e tal condição estabelece a dificuldade de enquadramento e classificação por gêneros, ou, em outras palavras, a dificuldade de definir um lugar social para uma prática que se confunde com a própria prática social, como o anúncio de Arago parece apontar quando atribui a ela a tarefa de "cobrir todos os aspectos da vida" ${ }^{10}$. Algo como o que Bourdieu afirmara sobre os usos objetivos que definem a verdade social da fotografia serem, ao mesmo tempo, definidos por ela ${ }^{11}$.

\footnotetext{
${ }^{7}$ BENIAMIN, op. cit., pp. 92-93.

${ }^{8}$ DOBRANZKY, op. cit.

${ }^{9}$ ZAMBONI, Sílvio. A pesquisa em arte: um paralelo entre arte e ciência. Campinas: Autores Associados, 2006, pp. 7-8.

${ }^{10}$ BENJAMIN, op. cit.

${ }^{11}$ BOURDIEU, Pierre. Un arte medio. Barcelona: Gustavo Gili, p.135.
} 
Joan Fontcuberta (1955, Barcelona) é um artista que faz uso da fotografia dentro desta perspectiva em se questionar os lugares sociais da fotografia, explicitando o diálogo entre arte e ciência. Ao mesmo tempo que questiona o valor documental da fotografia, reflexo de sua genealogia técnico-científica, faz uso do universo das artes para manifestar as contradições das componentes ficcionais e racionais dos ideais de criação.

Um de seus projetos mais expressivos, nesse sentido, seria "Secret Fauna", de 1987, em que forja todo um repertório de dados científicos atribuídos a um zoólogo do final do século XIX e que, segundo o artista, teria desaparecido misteriosamente. A exposição pública dessa obra trazia, além dos diários de trabalho do cientista e espécimes de animais dissecados, fotografias de campo e fotografias de família, contextualizando a vida e os trabalhos científicos do zoólogo. Esse repertório de imagens era fundamental para trazer a credibilidade necessária para todo esse universo criado pelo artista, fazendo uso, dessa forma, tanto do papel documental atribuído à fotografia ao final do século XIX, quanto da sua presença no cotidiano familiar.

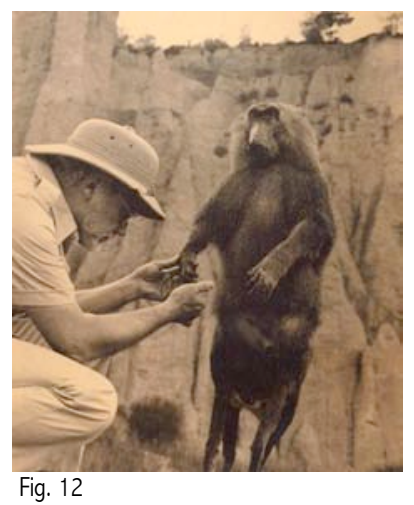

Fig. 12

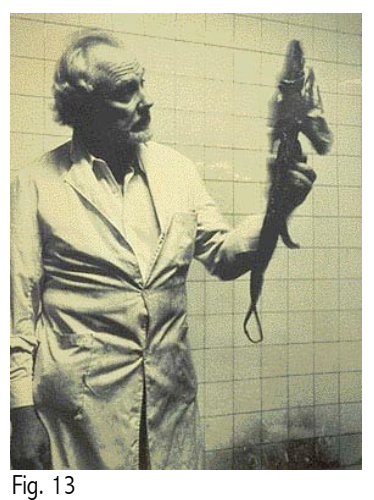

Fig. 13

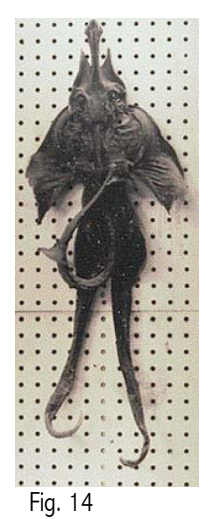

Fig. 14

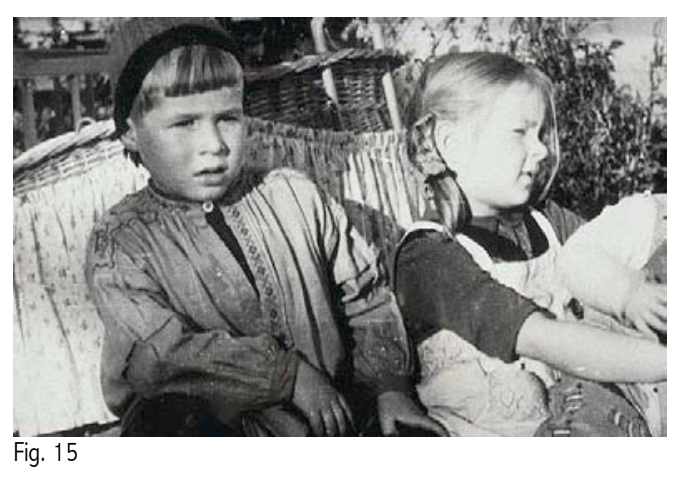

Figuras 12 e 13: zoólogo em trabalho de campo; figura 14: espécie animal; figura 15 (próxima página): fotografia da infância do zoólogo. Todas as imagens disponíveis no portfolio do artista em http://www.zonezero.com. 
Herbarium, de 1985², traz espécies botânicas forjadas e construídas por meio de restos de lixo e outros diversos materiais que, montadas e fotografadas em preto e branco, ganham aura documental indiscutível. Em Sputnik, de 199713, na história do "cosmonauta fantasma", novamente fotos biográficas e documentais de um relato fictício de um astronauta russo (protagonizado pelo próprio Fontcuberta) que, após fracasso de sua missão espacial, é abandonado pelo seu prórpio governo, sendo que este teria tentado esconder o fato do restante do mundo. Com o fim da Guerra Fria, as imagens teriam sido redescobertas e todo o esforço do governo russo para esconder os fatos, agora seria revelado ao mundo. História espacial forjada por Fontcuberta, que chegou a ludibriar inclusive um programa de televisão na Espanha, que acreditava estar diante de um fato verídico ${ }^{14}$.
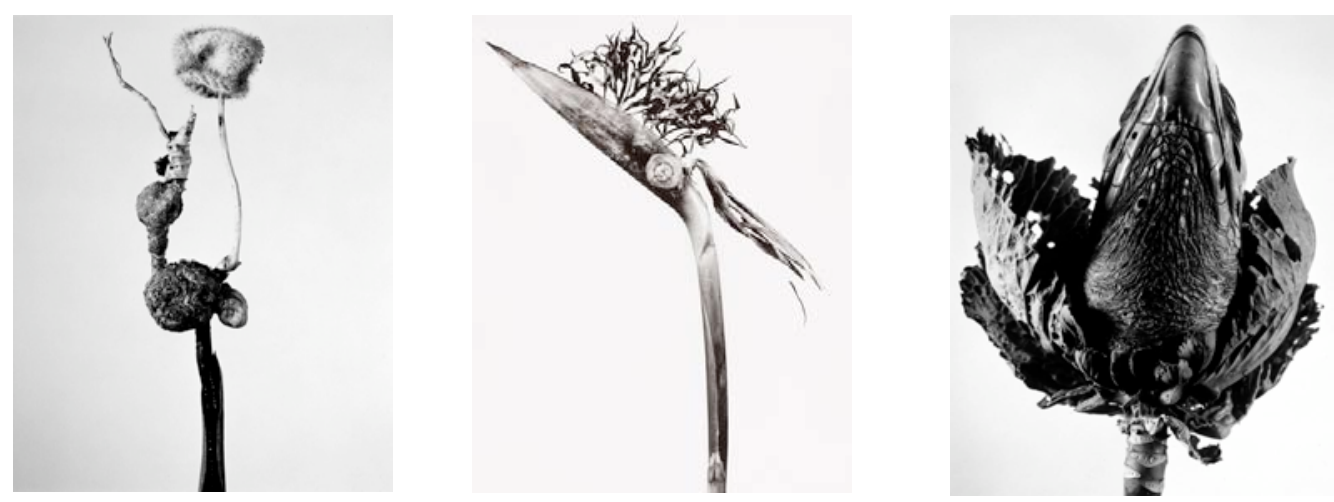

Fig. 16: Algumas imagens da série Herbarium .
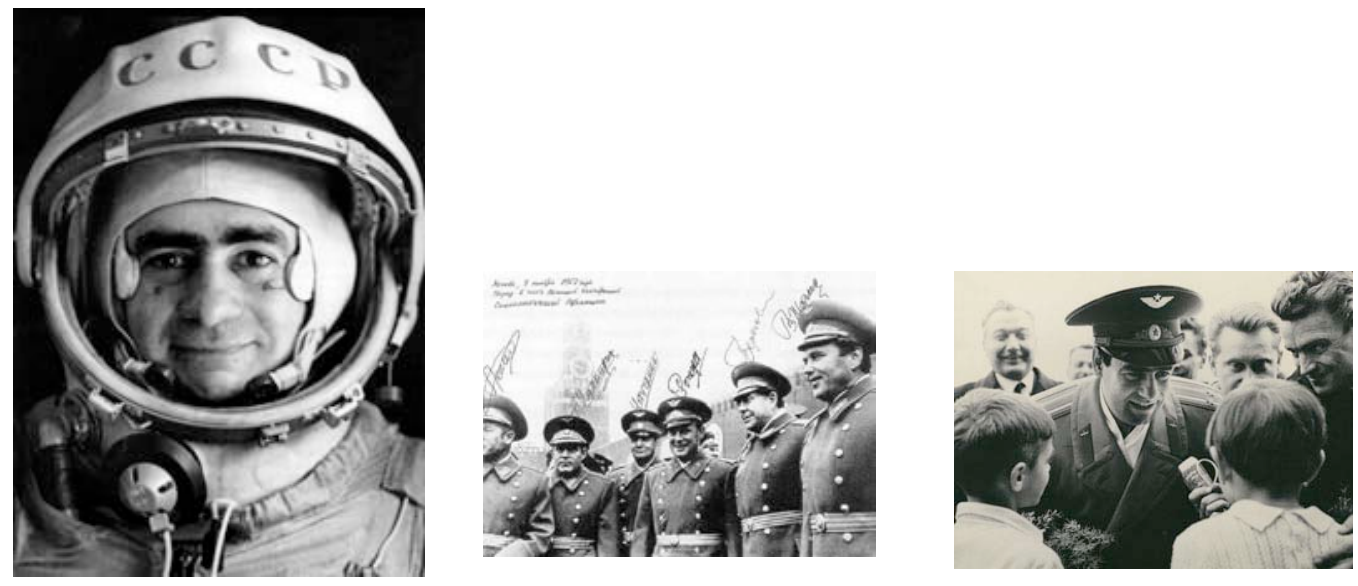

Fig. 17: Imagens manipuladas em Sputnik.

\footnotetext{
${ }^{12}$ FONTUBERTA, Joan. Herbarium. Gottingen: European Photography, 1985.

${ }^{13}$ FONTUBERTA, Joan. Twilight zones. Barcelona: Actar, 2000.

${ }^{14}$ Trata-se do programa de TV "Cuarto Milenio", do canal Cuatro, apresentado por Iker Jimenez, que investiga fenômenos paranormais e conspirações. 0 vídeo está disponível no youtube no endereço http://www.youtube.com/watch?v=zbRyjk2anVM.
} 
Procurando ressaltar de forma recorrente a dualidade ficção/razão inerente a qualquer imagem fotográfica, Fontcuberta busca evidenciar como o caráter documental, que foi o cerne da prática desde seu surgimento (manifestado sobretudo pelo fotojornalismo e pela fotografia científica), dificulta o estabelecimento de horizontes subjetivamente mais expressivos e mais questionadores, uma vez que uma atuação fotográfica nessa direção estaria sustentada muito mais pelas oscilações semânticas balizadas por extremos, vale dizer, por uma instabilidade, do que pelas certezas que lhe são atribuídas. Em sua coletânea de ensaios El Beso de Judas Fotografía y verdad (obra dedicada a Vilém Flusser), Fontcuberta aponta o teor questionador de seus trabalhos em relação ao potencial documental da fotografia. Observe-se a passagem:

\footnotetext{
Toda fotografía es una ficción que se presenta como verdadera. Contra lo que nos ha inculcado, contra lo que solemos pensar, la fotografía miente siempre, miente por instinto, miente por que su no le permite hacer otra cosa. Pero lo importante no es essa mentira inevitable. Lo importante é cómo la usa el fotógrafo, a qué intenciones sirve. Lo importante, en suma, es el control ejercido por el fotógrafo para imponer una direción ética a su mentira. El buen fotógrafo es el que miente bien la verdad. ${ }^{15}$
}

Ao questionar as estruturas autoritárias em que se insere a fotografia, Fontcuberta abala o caráter tecnológico da prática, quando entendido como reflexo da ciência moderna. Sendo assim, denuncia o caráter ficcional presente em qualquer ciência, situando a fotografia como uma técnica que não mais encontra fundamento no pensamento científico, apesar de ter sido por ele originada. 0 que significa que a fotografia, pelas mãos de Fontcuberta, questiona seus próprios alicerces estruturadores.

Os exemplos citados até aqui aproximam-se de um universo fotográfico mais estruturado e conectado com o universo científico positivista, atingindo assim os componentes do caráter documental da fotografia fundados em suas origens. Ao longo do século XX, tal como se insiste aqui afirmar, este caráter foi sendo atenuado em medida igual aos tecnicismos que cada vez menos tornaram-se necessários para o exercício da prática fotográfica. "Facilidade rima com banalidade", diz Jorge Coli ${ }^{16}$, e tal como será exposto na segunda parte deste estudo, a fotografia digital parece ser um passo definitivo em direção a uma ideia de práxis que não tenha com ponto de partida a sua condição de documento.

\footnotetext{
${ }^{15}$ FONTCUBERTA, Joan. El beso de Judas: fotografia y verdad. Barcelona: Gustavo Gili, 1997.

${ }^{16}$ COLI, Jorge. Rascunhos e harmonias. São Paulo: Folha de S. Paulo, Caderno Mais, p. 2, 6 de agosto de 2006.
} 
Mas mesmo reconhecendo esse universo contemporâneo com "amarras mais frouxas" entre fotografia e verdade, Fontcuberta encontra espaço para este tipo de questionamento, pois, segundo ele, mesmo que o repertório visual da sociedade esteja sendo aprimorado, os mecanismos de manipulação também se aprimoram ${ }^{17}$. Para 0 artista, a preocupação em desmantelar a autoridade destes mecanismos ainda deve ser objeto de reflexão.

Essa linha de atuação, já atualizada no universo digital, pode ser demonstrada e reforçada por um de seus trabalhos mais recentes, "Googlegrams", de 2005, em que constrói mosaicos fotográficos por meio de imagens encontradas na internet via "Google", buscadas a partir do assunto de que trata o motivo de cada um dos painéis. A figura 18 traz um "Googlegram" produzido a partir de uma das fotografias dos soldados norte-americanos que teriam torturado prisioneiros iraquianos na prisão de Abu Ghraib. Vê-se em "Googlegrams", a preocupação que motiva o trabalho de Fontcuberta, agora atualizada perante os mecanismos contemporâneos de construção de verdades: um jogo entre um universo de imagens, facilmente encontráveis e descartáveis, e um universo de imagens pontuais que definem rumos sociais e políticos, e efetivamente influenciam na estruturação das unidades de poder, além de, cabe retomar, corroborar a ideia da "história-através-da-fotografia" de Lemagny.

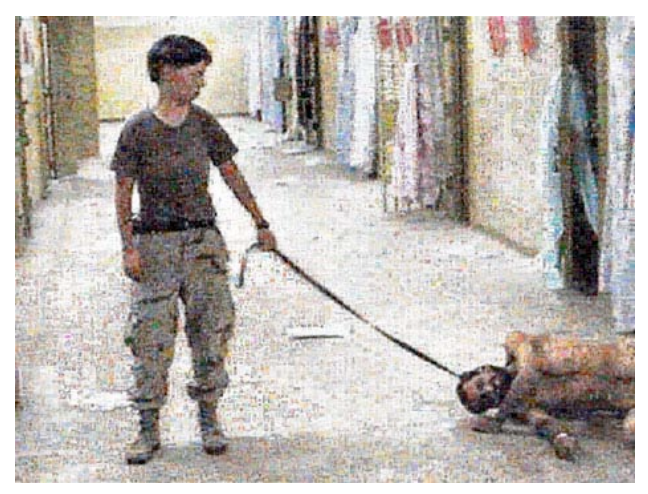

Fig.18: "Abu Ghraib", de Joan Fontucberta, 2005 (imagem e detalhe).

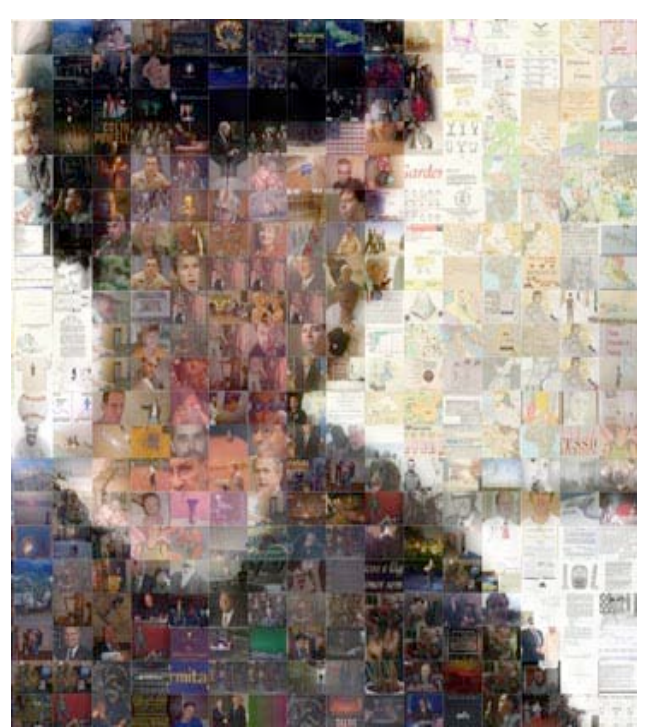

\footnotetext{
${ }^{17}$ Ver entrevista em anexo, realizada em São Paulo no dia 13/10/2009, que foi possível graças a sua vinda ao Brasil para participação na mostra "A invenção de um mundo", realizada no Itaú Cultural, na mesma cidade, com fotografias da coleção da Maison Européenne de La Photographie de Paris.
} 
Por mais que a imagem possa ser banalizada na contemporaneidade, Fontcuberta ainda lembra que esta banalização não destrona totalmente o potencial documental imbricado em suas raízes. Em outros dois trabalhos recentes, Deconstructing Osama (2007) ${ }^{18}$ e Miracles \& Co. $(2003)^{19}$, a crítica ao fluxo de informação se mantém, mas agora dirigida ao universo do fotojornalismo contemporâneo: no primeiro, tem-se o foco nas contradições que envolveram 0 caso da caça a Osama Bin Laden, após o atentado de 11 de setembro de 2001, onde o seu incriminamento parece ter sido mais justificado pela massiva divulgação de sua imagem de culpado (nesse trabalho, é o próprio Fontcuberta que atua como suposto repórter disfarçado); no segundo, o artista constrói também uma narrativa de um furo de reportagem em que um repórter (também protagonizado pelo artista) frequenta um mosteiro escondido entre a Rússia e a Finlândia, que ensina como fazer milagres. Ambos os trabalhos retomam a estrutura ficcional tal como desenvolvida em Secret Fauna, mas agora num tom evidentemente bem mais irônico e humorístico.
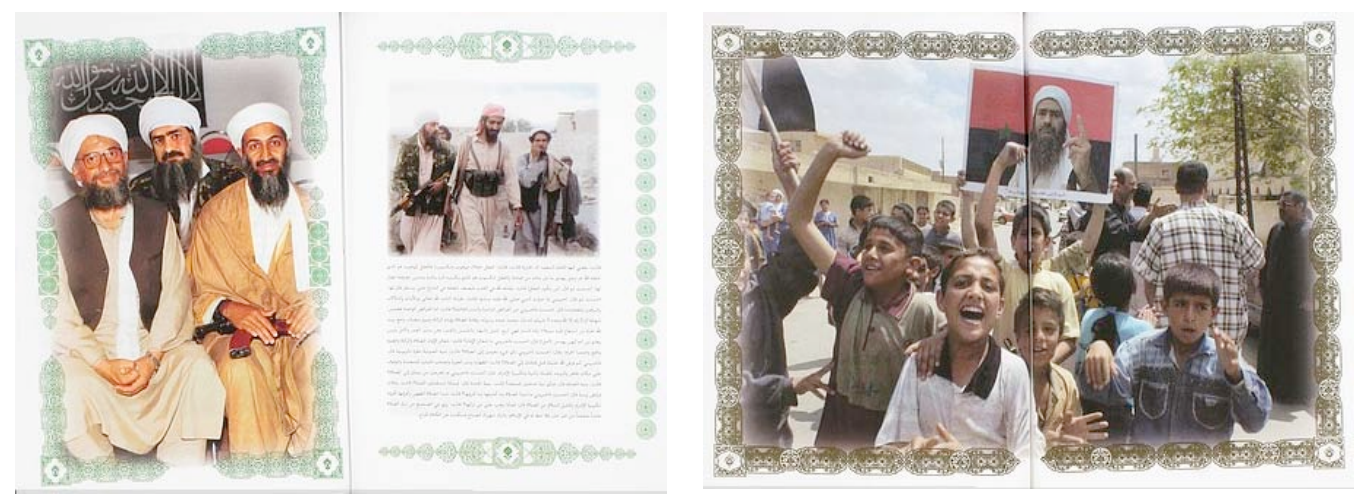

Figura 19: Algumas imagens do livro Deconstructing Osama.

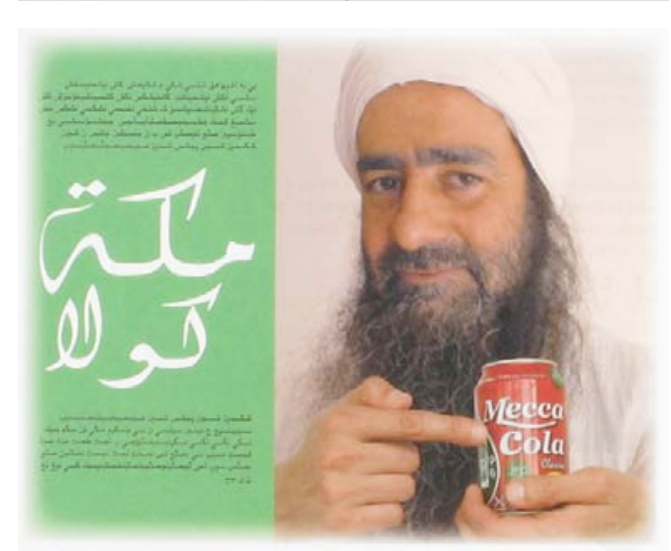

\footnotetext{
${ }^{18}$ FONTCUBERTA, Joan. Deconstructing Osama: the truth about the case of Manbaa Mokfhi. Barcelona: Actar, 2007.

${ }^{19}$ Idem. Miracle \& Co. Fotografias. Disponível em http://www.zabriskiegallery.com. Acesso em agosto de 2009.
} 

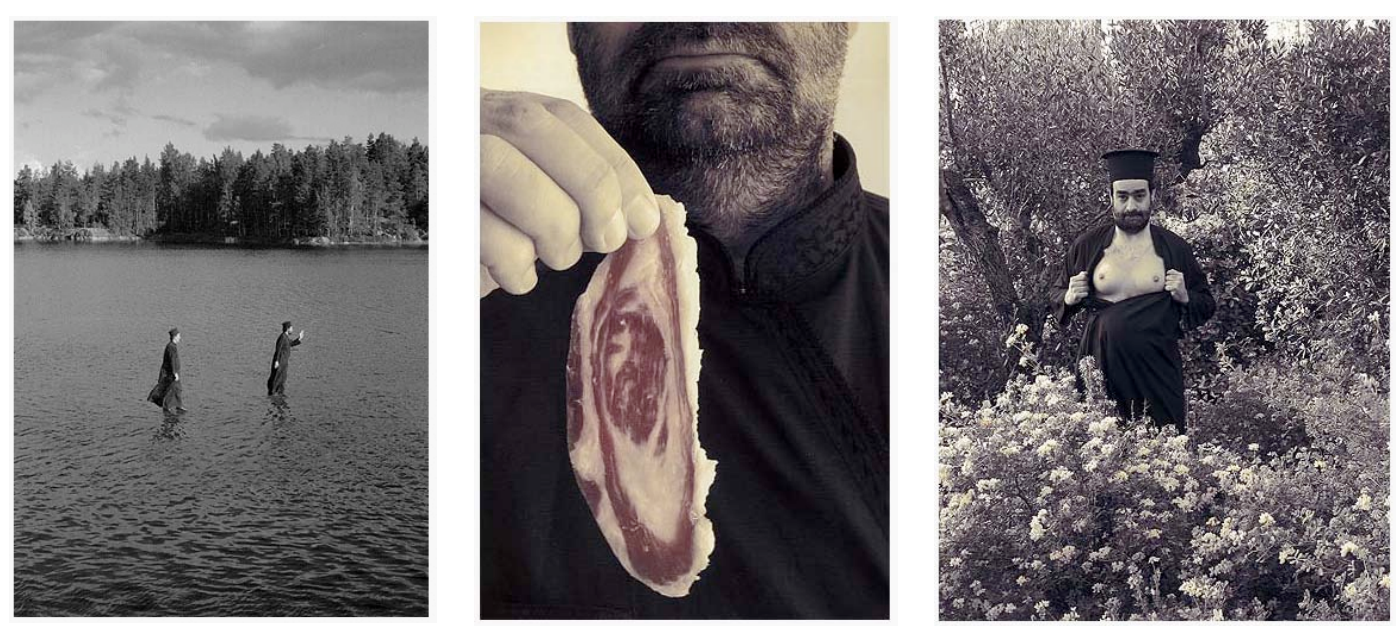

Figura 20: algumas imagens de Miracles \& Co.

Os trabalhos de Fontcuberta mostram que a fotografia lida com elementos que se conectam mais com valores sociais do que com lugares sociais, e isto é o ponto crucial que envolve a dificuldade de sua classificação em gêneros. É preciso dar nova dimensão à tecnologia fotográfica, assumir sua objetividade, mas buscando a sua retirada de dentro desses invólucros, os gêneros, se se quiser aproximação de nova ordem.

Seu lugar social parece ser mais abrangente do que as opções oferecidas por práticas já instituídas. Deve-se explorar seu caráter específico que, como observa Allinovi, é de "um instrumento preciso e infalível como uma ciência e, ao mesmo tempo, inexato e falso como a arte (...) encarna a forma híbrida de uma 'arte exata' e, ao mesmo tempo, de uma 'ciência artística', o que não tem equivalentes na história do pensamento ocidental"20.

\footnotetext{
${ }^{20}$ ALLINOVI apud FABRIS, op. cit., p. 173.
} 


\section{DAS FOTOGRAFIAS À FOTOGRAFIA}

0 que se tentou demonstrar no capítulo anterior foi a necessidade existente de se atribuir valores à fotografia que não são sustentados por sua natureza, mas sim por práticas sociais já instituídas. É por isso que o trabalho de Fontcuberta talvez ganhe evidência, pois denuncia essa impossibilidade de classificação, ao confundir o teor dos gêneros que são atribuídos à fotografia. No fundo, busca-se sempre classificar fotografias, que nada mais é do que classificar o motivo representado. Mas o específico da fotografia parece se perder nessa postura fragmentadora e de categorização.

Barthes teria considerado a fotografia inclassificável, foi apontado anteriormente. Isto se deu em $A$ câmara clara, quando decide não mais constituir um corpus científico, "mas somente alguns corpos", tomando como ponto de partida para a sua investigação "apenas algumas fotos"1. Em suas abordagens semiológicas anteriores ao livro $A$ câmara clara, Barthes se debruçara sobre o fotojornalismo principalmente, reconhecendo ali uma prática que muito dialoga com o texto, dadas as suas inevitáveis conexões que surgem em virtude de o jornal ser um meio impresso que conjuga texto e imagem, o que teria permitido ao semiólogo encontrar terreno fértil

\footnotetext{
${ }^{1}$ BARTHES, A câmara clara, op. cit, p. 19.
} 
a fim de que pudesse sustentar bases sólidas para o desenvolvimento de sua ciência calcada na linguística de Saussure ${ }^{2}$.

"Quem volta no tempo, avança no conhecimento", teria dito Debray33. Necessário, portanto, além de rever a tecnologia e os gêneros, retroceder a esta trajetória barthesiana que representa uma evolução, ou pelo menos, um movimento evidente de amadurecimento de postura teórica diante da fotografia, e que pode servir, em todo o seu conjunto, como sustentação para evidenciar essas fragilidades ao redor de uma ideia de fotografia "fragmentada", construída a partir de sua absorção social como mecanismo técnico-científico.

São duas pontuações de Barthes, antes de assumir a postura antisemiológica de $A$ câmara clara, em 1981: a primeira, em 1961, no texto A mensagem fotográfica; a segunda, em 1964, no texto A retórica da imagem. Os dois textos representam um olhar ainda imerso na objetividade fotográfica que permeava o senso comum na época, e por isto são provas do que a fotografia representava nesse sentido.

Em sua primeira investida, $A$ mensagem fotográfica ${ }^{4}$, Barthes procura evidenciar as dificuldades em definir parâmetros para a análise de fotografias jornalísticas, as quais ele classifica como sendo dotadas de uma mensagem. Reconhece a autonomia estrutural da fotografia dentro do complexo texto-imagem das páginas de um jornal, o que o obrigará a desenvolver um método para a análise desse objeto. A intenção do semiólogo é buscar meios para a definição da mensagem contida na imagem. Usando como referência a estrutura linguística, sua abordagem se concentra na tentativa de localizar os códigos da mensagem fotográfica. Mas existiria a dificuldade em definí-los, pois a representação por códigos não the parecia evidente na fotografia: não via partilha do real em fragmentos a serem juntados novamente. A fotografia, segundo Barthes, é o "analogon perfeito" do real, é esta "perfeição analógica que define a fotografia para o senso comum" 5 . É quando conclui que a fotografia é mensagem sem código, uma "mensagem contínua". Mas para Barthes, nesta primeira abordagem, existiriam ainda outras estruturas que trazem mensagens sem código: o cinema, a pintura, desenho ou teatro. Mas tais mensagens, por permitirem um "estilo" de produção,

\footnotetext{
${ }^{2}$ Segundo Saussure, "A língua é um sistema de signos que exprimem idéias, e, por isso, é confrontável com a escrita, o alfabeto dos surdos-mudos, os ritos simbólicos, as fórmulas de cortesia, os sinais militares, etc. etc. Ela é, simplesmente, o mais importante de tais sistemas." In: ECO, Humberto. Tratado geral da semiótica. São Paulo: Perspectiva, 2007, p. 9.

${ }^{3}$ DEBRAY, Regis. Vida e morte da imagem. São Paulo: Brasiliense, 1994.

${ }^{4}$ In: BARTHES, R. $O$ óbvio e o obtuso., op. cit., pp 11-25.

${ }^{5}$ Idem, p. 13.
} 
carregariam uma possibilidade de conotação, o que não seria o caso da fotografia jornalística que, para ele, não é nunca uma fotografia artística:

\begin{abstract}
A fotografia, considerando-se como uma análogo mecânico do real, traz uma mensagem primeira que, de certo modo, preenche plenamente a sua substância e não deixa lugar ao desenvolvimento de uma mensagem segunda. Em suma, de todas as estruturas de informação, a fotografia seria a única a ser exclusivamente constituída por uma mensagem 'denotada", que esgotaria totalmente o seu ser. ${ }^{6}$
\end{abstract}

Segue ele dizendo que, "diante de uma fotografia, o sentimento de 'denotação', é tão forte, que a descrição de uma fotografia é, ao pé da letra, impossível". Mas é verdade também que ele enxergou nessa postura uma incômoda possibilidade de aproximação com o senso comum de mitificar a objetividade da fotografia. É quando lança a hipótese de que seria possível estabelecer códigos conotativos à fotografia, mesmo sendo esta uma mensagem sem código. Aqui reside o seu "paradoxo fotográfico"7: uma mensagem sem código que pode ser codificada. E onde estariam tais possibilidades de conotação? Barthes admite que por meio de um esforço em reconhecer os dois planos de significante e significado, isto é, um plano de expressão e um plano de conteúdo. E na busca para isolar tais unidades, propõe alguns elementos conotativos como possibilidades para a identificação do plano de expressão: trucagem, pose e objetos (modificação do real); fotogenia, estetismo e sintaxe (específicos da fotografia).

Reconhece ainda o texto jornalístico como outro procedimento de conotação, mas que, naquele momento, seria mero acessório para insuflar significados na imagem, apontando ainda uma inversão promovida pela objetividade da imagem: se antes a imagem esclarecia o texto, como "volta episódica a uma denotação", agora o texto exacerba, torna a imagem "mais pesada", "impondo-lhe uma imaginação"8. Barthes conclui que toda leitura de uma fotografia é histórica, e sempre dependeria do saber do leitor, sendo percebida quando verbalizada, a não ser no caso das fotos traumáticas (catástrofes, mortes violentas), que seriam aquelas que "nada se tem a dizer", pois "o trauma é precisamente aquilo que bloqueia a linguagem e interrompe a significação". Fotos traumáticas seriam, portanto, "fotos insignificantes" ${ }^{9}$, e torna-se oportuno apontar que essa constatação de Barthes será preciosa nos capítulos posteriores desta tese.

\footnotetext{
${ }^{6}$ Idem.

${ }^{7}$ Idem, p.14.

${ }^{8}$ Idem, p. 20.

${ }^{9}$ Idem, pp. 21-25.
} 
Já no texto seguinte, em A retórica da Imagem ${ }^{10}$, de 1964, Barthes toma a fotografia publicitária como objeto de análise por crer que esse tipo de fotografia traz "signos plenos" e "mensagens enfáticas". 0 objetivo é insistir na busca de códigos que possam articular 0 potencial da analogia como meio de mensagem, encontrando um meio termo entre dois polos extremos: aqueles que pensam ser a imagem "um sistema muito rudimentar em relação à língua", e aqueles que defendem que "a significação não pode esgotar a riqueza indizível da imagem"11.

Novamente insistindo na idéia da fotografia como mensagem sem código, localiza três planos de mensagens no anúncio publicitário que analisa, sendo a mensagem linguística, a imagem denotada e a imagem conotada: a primeira correspondendo ao texto do anúncio, a segunda aborda a fotografia em sua "plenitude analógica" e também como imagem literal e, por fim, na terceira mensagem, a imagem simbólica que a fotografia traz, em outras palvaras, busca situar a mensagem cultural conotada na imagem fotográfica.

Ao analisar a mensagem linguística'2, Barthes questiona a consideração recorrente sobre o fato de os indivíduos serem uma civilização da imagem: para ele, "somos ainda, e mais do que nunca, uma civilização da escrita", e esta deve ser considerada uma técnica para fixar a cadeia de significados flutuantes que podem ser atribuídos a uma mesma imagem. A mensagem linguística, ao combater o "terror dos signos incertos", orienta a interpretação da imagem, servindo como uma "espécie de barreira que impede a proliferação dos sentidos conotados". 0 texto é a possibilidade de controle, e "tem um valor repressivo (...) em relação à liberdade dos significados da imagem". Para Barthes, texto fixa significado no imenso universo de cada imagem.

Quando aborda o plano da imagem denotada, o semiólogo retoma e aprofunda sua ideia de mensagem sem código, desenvolvida no texto anteriormente citado. A fotografia não transforma, ela registra, mecanicamente e não humanamente, e isto, continua Barthes, reforça 0 mito do "natural fotográfico", ainda que se levasse em conta as intervenções no fazer fotográfico, pois este, na verdade, estaria no plano da mensagem conotada. A fotografia, como mensagem sem código, representaria uma revolução antropológica na história do homem, porque seu caráter específico revelaria um tipo de consciência implícita sem precedentes ${ }^{13}$.

\footnotetext{
${ }^{10}$ Idem, pp. 27-43.

${ }^{11}$ Idem, p. 27.

${ }^{12}$ Idem, pp. 31-34.

${ }^{13}$ Idem, pp. 34-37.
} 
Tais raciocínios de Barthes também devem ser considerados como os primeiros movimentos na afirmação da insuficiência da semiologia para lidar com o que a fotografia pode significar. Surgem, nesse momento, as primeiras alusões ao seu "isso-foi", que seria desenvolvido em $A$ câmara clara. Oberve-se a passagem:

Trata-se, pois, de uma nova categoria de espaço tempo: local e imediata e
temporal-anterior; na fotografia há uma conjunção ilógica entre o aqui e o
antigamente. É, pois, ao nível dessa mensagem denotada, ou mensagem
sem código, que se pode compreender plenamente a irrealidade real da
fotografia; sua irrealidade é a irrealidade do aqui, pois a fotografia nunca é
vivida como uma ilusão, não é absolutamente uma presença, e é
necessário aceitar o caráter mágico da imagem fotográfica; sua realidade é
a de ter estado aqui, pois há, em toda fotografia, a evidência sempre
estarrecedora do isto aconteceu assim: temos, então, precioso milagre,
uma realidade da qual estamos protegidos. ${ }^{14}$

E cabe dizer que a mesma passagem já demonstra o clima de abordagem em sua obra seguinte, A câmara clara, obra que será interpretada a seguir.

Em princípio, é importante notar que Barthes dedica tal texto ao ensaio "0 Imaginário", de Sartre ${ }^{15}$, e isto já circunscreve a dimensão de suas reflexões que estarão por vir. Para Sartre, a imaginação é tão objeto quanto qualquer outro objeto dito real, e sua presença é tão decisiva quanto qualquer outra interferência externa ao humano. Um dos principais aspectos que apontam sobre esse imaginário é a espontaneidade com que este pode se dar no homem. Essa espontaneidade da imaginação é liberdade pois se constrói sem determinismos, sendo também reflexo do desejo que nunca pode ser controlado, ao contrário da vontade que já se projeta sob uma esfera social, pois é essa vontade que consiste no caminho para a execução do desejo. "A consciência imaginante é ato livre, criador e não está ligada à vontade porque está vinculada ao desejo." $^{16}$

Na expressão de Sartre, essa liberdade imaginativa em compor um irreal material, ou melhor, um imaginário que é efetivo tanto quanto o real, constitui-se um ato de magia, pois é a produção de um encantamento que promove, num certo sentido, a aparição de objetos desejáveis. Em Sartre, a imagem não é só representação, ela é principalmente fonte de desejo

\footnotetext{
${ }^{14}$ Idem, p. 36.

${ }^{15}$ Sartre possui duas obras com nomes distintos, mas bastante próximos : L'imaginaire, de 1940 e L'imagination, de 1936, que possui tradução para o português (SARTRE, Jean-Paul. A imaginação. São Paulo: Abril, 1978.)

${ }^{16}$ ARRUDA, F. D. A questão do imaginário: a contribuição de Sartre. In: Em Aberto, ano 14, n. 61, jan/mar 2004. Brasília: Ministério da Educação, 2004, pp. 79-85.
} 
que se converte em vontade e faz o homem agir. Um homem sem imaginação perde a sua essência, a sua possibilidade de ser. Segundo Sartre, a liberdade da existência não se dá no plano imaginário, mas é por meio deste plano que o homem articula sua ação e se projeta para 0 futuro: o não-ser imaginário torna-se o vir-a-ser real.

0 que Barthes faz em A câmara clara é um exercício de liberdade. É, dentro dos termos de Sartre, a manifestação de seu desejo. 0 tom assumidamente subjetivo ao longo do texto reforça a sua única estratégia de afirmar a "soberania do eu" (Nietzsche) como princípio heurístico ${ }^{17}$. E 0 abandono anunciado da ciência semiológica é a busca de abertura, é tentativa de lidar com um objeto que escapa de suas categorias até então estabelecidas nos textos anteriores. Barthes assume em seu ensaio o caráter de "escritura", flertando com o poético (onde sabor e saber se encontram), revelando, assim, o abandono de uma postura epistemológica em favor de um discurso dramático ${ }^{18}$.

Em A câmara clara, suas reflexões se constroem num relação conflitiva com a fotografia. Todo o contexto de abordagem de Barthes se dá num tom evidentemente angustiante, sobretudo pela morte recente de sua mãe, situação que o fizera passar a viver uma vida "inqualificável (sem qualidade)", conforme ele mesmo afirma no texto (p.113). Diversas são as passagens que revelam o conflito de Barthes: "a vida é, assim, feita a golpes de pequenas solidões" (p.11); "eu me encontrava num impasse e, se me cabe dizer, cientificamente sozinho e desarmado"; "eu tinha de descer mais ainda em mim mesmo para encontrar a evidência da fotografia" (p. 91); "é preciso, portanto, que eu me renda a essa lei: não posso aprofundar, penetrar a fotografia"(p.156). A conclusão calcada na ideia do "êxtase fotográfico", sendo este "o movimento revulsivo" de trazer à consciência a própria "letra do tempo" (p. 175), revela que Barthes assume a fotografia como "uma nova forma de alucinação", "imagem louca com tinturas de real" (p.169). A câmara clara é um confronto direto com o "terror da polissemia", um mergulho no que ele chama de "plenitude analógica da fotografia", o enfrentamento daquela presença que traz aquilo que ele teria denominado como uma irrealidade real.

E aqui cabe retomar a proposta do paralelo entre o pensamento de Barthes sobre a fotografia e a própria prática social da fotografia. A trajetória de Barthes se inicia com 0

\footnotetext{
${ }^{17}$ BARTHES, A câmara clara, op. cit., 1984, p.19.

18 "A ciência é grosseira, a vida é sutil, e é para corrigir essa distância que a literatura nos importa (...) através da escritura, 0 saber reflete incessantemente sobre o saber segundo um discurso que não é mais epistemológico, mas dramático (...) a escritura se encontra em toda a parte onde as palavras têm sabor (saber e sabor têm, em latim, a mesma etimologia) (...) in: BARTHES, Roland. Aula. São Paulo: Cultrix, 1988, pp. 17-19.
} 
reconhecimento da objetividade fotográfica, o que é visível quando forja o conceito de mensagem sem código e quando opta por analisar fotografias jornalísticas e publicitárias: é um momento em que se agarra aos gêneros fotográficos, aos lugares sociais da fotografia. Neste primeiro texto, essa evolução de seu pensamento, que aqui se afirma, já pode ser vislumbrada quando fala das fotos traumáticas. Quando aprofunda seus temas no segundo texto, dando mais espaço para uma abordagem distanciada dos gêneros, tenta evidenciar a dificuldade em categorizar a fotografia, ou classificar seus conotadores (o que seria a retórica da imagem), reconhecendo a sua autonomia no universo da linguagem.

Pois a investigação que se desenrola em $A$ câmara clara é motivada por aquilo que ele vai chamar de "o novo do qual a fotografia pode ter sido o advento", dando continuidade às conclusões parciais dos dois primeiros textos que podem ser resumidas, tal como em suas próprias palavras, em delinear a fotografia como uma "revolução antropológica na história do homem".

Mas mesmo que Barthes, em seu último texto, tenha apresentando uma abordagem que sugere adentrar com mais pertinência nas especificidades fotográficas, especificamente por não levar tanto em conta os lugares sociais da fotografia, suas análises em $A$ câmara clara ainda mantêm certa necessidade de conexão com o referente fotográfico. Apesar de objetivar a essência da fotografia, Barthes se detém demasiadamente na descrição dos conteúdos das imagens, tendo a necessidade de mapear estas aproximações por meio da criação de novos conceitos até, a saber, o studium e o punctum.

Isso quer dizer que, Barthes, a despeito de buscar esse possível "novo" que a fotografia possa ter trazido, denunciar que toda e qualquer fotografia é traumática, sendo que essa constatação é o que faz de sua pequena trajetória uma peça fundamental na evolução de uma abordagem à fotografia, sua postura em falar da fotografia por meio da análise de fotografias, de certa maneira, também sustenta o que Legmany apontou sobre a "história-através-da-fotografia".

Philippe Dubois, em 0 Ato Fotográfico $^{19}$, afirma que a posição adotada por Barthes consistiu num ato de loucura, resultado do culto ao universo da "referência pela referência". Dubois, ao contrário do semiólogo, tenta compreender a fotografia por meio do ato que a faz ser. Mas apesar de a epífrase de seu texto, "o que se fotografa é o fato de se estar tirando uma

\footnotetext{
${ }^{19}$ DUBOIS, Philippe $O$ ato fotográfico e outros ensaios. Campinas: Papirus, 1994.
} 
foto" ${ }^{20}$, sugerir que sua abordagem tenderia a tratar mais do ato da tomada fotográfica, ou seja, da técnica, Dubois opta por priorizar, em muitos momentos, o ato da recepção, em outras palavras, também busca nas fotografias o ponto de partida para as suas análise. Além do mais, a insistência do autor em fundamentar a fotografia como índice peirceano revela também a sua tendência em priorizar o objeto referente, ainda que, para ele, a semiótica de Charles Peirce permita linhas de análise que the parecem "mais sutis e mais sérias" do que a adotada por Barthes, pois relativiza mais "o campo e o domínio da referência" ${ }^{21}$.

Contudo Barthes quanto Dubois adotam posturas que se sustentam num ponto comum: os dois autores não parecem adentrar no objeto fotografia de forma que não seja por meio do mundo objetivado por ela. Buscam tratar da fotografia, mas acabam por tratar de fotografias: Barthes declaradamente, veja-se a foto do jardim de inverno de sua mãe, entre inúmeras outras; Dubois mais discretamente, veja-se principalmente a foto emblemática de Michael Snow na complexa descrição na abertura do livro ${ }^{22}$.

Ao contrário de Barthes e Dubois, dois exemplos de análise semântica da imagem fotográfica, o pretendido aqui é uma via de abordagem que se sustente mais pelos componentes técnico/técnológicos, o que permitirá, assim parece, tomar as imagens fotográficas "no atacado"23. Das fotografias passar à fotografia.

Ora, é justamente tendo em vista que um dos aspectos mais perturbadores do universo digital consiste na possibilidade sempre presente da manipulação e aniquilação de qualquer referente, que um outro horizonte de abordagem deve surgir. É por essa razão que a via da técnica, ao contrário da via das imagens, sugere uma possibilidade de redução que pode permitir uma compreensão intrínseca ao processo, dentro do próprio universo do mecanismo da fotografia.

\footnotetext{
${ }^{20}$ ROCHE, Denis apud DUBOIS, Philippe, op. cit., p.11.

${ }^{21}$ DUBOIS, Philippe, Op. cit., p. 49.

${ }^{22}$ Numa conferência realizada em 1/9/09, em São Paulo, intitulada "As tensões na fotografia: entre o real e a ficção", Dubois realiza a revisão de sua perspectiva desenvolvida no primeiro capítulo de 0 ato fotográfico. Numa autocrítica, o autor afirma que sua proposta teria sido muito esquemática e rigorosa na classificação do significado da fotografia ao longo de sua própria história, que foi fundamentada nos conceitos de índice, símbolo e ícone de Peirce. Admite, hoje, que as categorias equivalentes que ele teria criado, ou seja, as fases do espelho do real (ícone), transformação do real (símbolo) e traço do real (índice) não poderiam ser compartimentadas daquela forma: toda fotografia pode apresentar oscilações e permutas por entre essas três categorias. Concorda, portanto, que tal classificação não se sustenta na contemporaneidade, uma vez que o universo digital reconfigura a "paisagem prática" em que se insere a imagem fotográfica. Segundo ele, se redigisse o capítulo hoje, ele enquadraria a posição de Barthes dentro de uma postura fenomenológica, não cabendo julgamento por meio de uma comparação entre a semiótica e a semiologia.

23 "Com o hibridismo que dilui as fronteiras entre as formas tradicionais da arte e a difusão dos sistemas digitais que retiram da imagem a diferença de seu suporte, algo do que é propriamente fotográfico aparenta evanescer-se. Agora, portanto, ao modo de Benjamin, pode ter chegado o momento de arrematar a fotografia no atacado". In: LISSOVSKY, op. cit.
} 
É certo que o estado virtual a que é comumente associado o universo numérico, nomeadamente no caso da simulação, tem uma dimensão peculiar no caso da fotografia. É verdade que a imagem de uma câmera digital torna-se números no momento do registro e adquire esta virtualidade, mas é neste mesmo momento que ela ainda mantém relação com os dados brutos do real, quando praticada da forma convencional. Nesse sentido, tal como apontou Dubois, o ato que constitui a imagem fotográfica deve ser levado em conta e é decisivo para se enquadrar a fotografia ainda nos moldes da representação.

A fotografia é uma tecnologia que ocupa um ponto estratégico nestas relações do universo digital, pois ao mesmo tempo em que o real continua sendo a sua "matéria-prima", ela também se investe de possibilidades na esfera da simulação. Ela não se enquadra necessariamente na idéia de um real paralelo constituído apenas por aquilo que pode ser modelizável: ela é, muitas vezes, o próprio modelo.

Em outras palavras, não se pode afirmar, em relação à fotografia, que sua imagem é a do tipo que "não mantém mais nenhuma ligação física nem energética com o real", como Couchot define a simulação, mas por outro lado, ainda nos termos desse autor, ela pode tornar-se também a "expressão de uma linguagem específica - a linguagem dos programas informáticos alimentados por algoritmos e por cálculos" 24 .

Justamente por ocupar este ponto estratégico, oscilando entre a representação e a simulação, é que a fotografia parece exigir um modelo de compreensão que esteja imbricado em sua própria estrutura tecnológica, um modelo ainda anterior ao significado de suas imagens produzidas, fundamentalmente tendo em vista as reconfigurações encetadas pelo universo numérico.

Quem adota esta linha de definição é Vilém Flusser. Em seu pensamento, vê-se a possibilidade de adentrar no universo fotográfico sem a necessidade da abordagem de gêneros fotográficos, ou de definir qualquer referente, pois a sua definição de fotografia como imagem técnica equaliza toda a objetividade fotográfica numa única direção. No próximo capítulo pretende-se explorar o modelo de Flusser.

\footnotetext{
${ }^{24}$ COUCHOT, op. cit., pp 155-157.
} 
É fato que o advento da fotografia representou um marco na trajetória das imagens. No entanto, se cabe a pertinência da assertiva de que a fotografia foi absorvida como tecnologia a serviço de uma prática imagética estruturada pela arte pictórica, o seu desenvolvimento ao longo do século XX não correspondeu exatamente ao desenvolvimento de um traço próprio de existência, apesar de toda a sua onipresença em diversos âmbitos da esfera social. Ora, se "o espírito humano é feito de tal maneira que ele só começa a compreender o novo depois de ter tentado tudo para reduzi-lo ao antigo", como afirma Henri Bergson ${ }^{1}$, poder-se-ia dizer que os avanços tecnológicos da fotografia, bem como a sua práxis tal como realizada, foram tentativas recorrentes de compreensão do novo que ela trouxe?

Deve-se reapresentar a tese: aqui se afirma que, em meio digital, isto é, em meio a zeros e uns, a prática da fotografia tem agora disponível uma tecnologia aprimorada que não representa exatamente uma nova forma de se fazer fotografia, mas uma nova forma para apreendê-la. Tal aprimoramento é, na verdade, o simples acabamento daquilo que se iniciou com

\footnotetext{
${ }^{1}$ BERGSON, H. A intuição filosófica. In: Cartas, conferências e outros escritos. São Paulo: Nova Cultural, 2005, p. 82.
} 
o seu advento, e hoje aponta para o que há de mais elementar e original na técnica fotográfica, elemento este que esta tese busca apreender, e, cabe dizer, adotando também o mesmo ponto de partida de Lissovsky quando afirma que "a origem só pode ser plenamente verificada 'depois': depois de seu advento e depois de seu hábito" ${ }^{2}$.

Mas o objetivo é observar o significado da fotografia a partir de sua tecnologia, e não necessariamente a partir dos processos de recepção às suas imagens. Ocupar-se com o potencial semântico das imagens não parece ser início promissor, dada toda a genealogia da prática de imagens na arte pictórica. É preciso buscar modelo que faça a distinção ontológica da imagem fotográfica diante da imagem pictórica, modelo este desenvolvido por Vilém Flusser, o qual, por meio de sua filosofia, propõe uma outra concepção de fotografia.

Flusser, em A filosofia da caixa preta, ${ }^{3}$ é categórico ao classificar a fotografia como imagem técnica ${ }^{4}$, e assim contornar a dificuldade com a qual Barthes se deparou ao tentar constituir seu "corpus": qualquer fotografia, antes de representar qualquer coisa que seja como imagem, representa conceitos; em outras palavras, uma imagem fotográfica representa todo 0 repertório de conhecimento que nela está imbricado ou, mais precisamente, representa texto científico aplicado, que é a escrita aprimorada.

Ao analisar a estrutura da imagem fotográfica por meio da relação entre técnica, imagem e conhecimento, Flusser propõe um mapa do significado da fotografia em qualquer que seja a sua aplicação. No intuito de compreender tal dimensão do papel que a fotografia pode cumprir, tornase fundamental entender, antes de tudo, como Flusser contextualiza a criação da técnica da fotografia na história, a partir da análise da relação entre texto e imagem ${ }^{5}$.

Para o autor, o surgimento da escrita no segundo milênio a.C. tinha o objetivo de combater a idolatria das imagens, uma vez que a capacidade do homem para decifrá-las, a imaginação, passava a ser substituída por alucinação. Em outras palavras, as imagens, mediadoras da relação do homem com o mundo, não só mais o representavam, mas passavam também a escondê-lo. 0 homem perdia a visão do mundo concreto e "ao invés de se servir das imagens em função do mundo, passava a viver em função das imagens". A escrita, portanto, visando a traduzir cenas em conceitos, "rasgava" as imagens para o homem ir de encontro ao

\footnotetext{
${ }^{2}$ LISSOVSKY, op. cit.

${ }^{3}$ FLUSSER, Vilém. Filosofia da caixa preta. Rio de Janeiro: Relume Dumará, 2002.

${ }^{4}$ Idem, pp. 13-18.

${ }^{5}$ Idem, pp. 9-11.
} 
mundo. Mas a crise seria inevitável porquanto estes conceitos, ao representarem as imagens, que por sua vez representavam o mundo, tornavam-se cada vez mais difíceis de ser decifrados e cada vez mais inimagináveis. "0 texto tampa imagens que tampam o mundo", e "ao inventar a escrita, 0 homem se afastou ainda mais do mundo concreto quando, efetivamente, pretendia dele se aproximar". Surgiu a textolatria, "fidelidade ao texto", tão alucinatória quanto a idolatria que, na opinião de Flusser, podia ser facilmente constatável em ideologias e nas ciências exatas do século XIX. Exatamente o momento em que surgia a fotografia que, para o autor, buscava ultrapassar a "crise dos textos"6.

Imagens técnicas são frutos de textos científicos aplicados, afirma Flusser, e a fotografia inaugurou tal possibilidade. Toda a tecnologia que se materializa nos aparelhos que permitem a produção de imagens é proveniente dos séculos de aprimoramento da escrita, e consequentemente, dos textos e conceitos. "Imagens tradicionais precedem os textos por milhares de anos" (como as pinturas rupestres), e "as imagens técnicas sucedem aos textos altamente evoluídos" (ciências exatas). "Ontologicamente, as imagens imaginam o mundo e as imagens técnicas imaginam textos que imaginam o mundo."7

Desde Aristóteles fazendo uso da camera obscura para a observação de um eclipse no século IV a.C., à divulgação mundial da técnica do daguerreótipo em 1839, a fotografia encontrou subsídios científicos na química do escurecimento dos sais de prata de Albert Le Grand no século XIII, na óptica de Jérome Cardan propondo o uso do vidro como lente convergente no século XVI, na mecânica de Daniel Barbaro que introduziu o diafragma ao sistema no mesmo século, e nas experiências de Niépce com o betume da Judeia em 18198. A própria conceituação da perspectiva artificial como método de transposição da realidade para o plano bidimensional, mesmo parecendo isenta, deve ser levada em conta nesta análise da amplitude científica que sustenta a fotografia e, tal como afirma Flusser, prefiguram o seu uso prático. 0 filósofo, enfim, busca desmontar o logos presente na techné da fotografia.

É por tais razões científicas de estruturação da fotografia que Flusser acredita que imagens técnicas "são dificilmente decifráveis pela razão curiosa de que aparentemente não necessitam ser decifradas". Ao ressaltar o caráter automático da impressão da imagem técnica sobre uma superfície (onde no caso da fotografia se trata do contato entre luz e superfície

\footnotetext{
${ }^{6}$ Idem, p. 11.

${ }^{7}$ Idem, p.13.

${ }^{8}$ AMAR, op. cit., pp. 11-16.
} 
fotossensível), o que foi permitido pelo constante aprimoramento dos textos científicos, seu significado torna-se óbvio, e a evidência de sua realidade representada (seu caráter perigosamente não-simbólico), a torna simplesmente produto do mundo. É dessa aparente objetividade fotográfica que o senso comum se serve.

Mas a importância dessas imagens, segundo o filósofo, deve ser comparada historicamente à importância da escrita. "Textos foram inventados no momento da crise das imagens, a fim de ultrapassar o perigo da idolatria. Imagens técnicas foram inventadas no momento de crise dos textos, a fim de ultrapassar o perigo da textolatria." Cabe às imagens técnicas estabecer um código geral para reunificar uma cultura fragmentada em textos hermeticamente inacessíveis (sobretudo os científicos), textos baratos (livros, jornais, panfletos) e imagem marginalizada em guetos (museus, exposições). Uma intenção implícita que - 0 autor acentua - precisa ser explicitada. ${ }^{9}$

$\mathrm{Na}$ verdade, essa relação entre texto e imagem proposta pelo filósofo consiste num reflexo de uma proposta maior, que é a da relação entre a linguagem e a realidade, dualidade que compõe o título de seu primeiro livro editado ${ }^{10}$. Nesta obra, o filósofo admite a ciência como uma língua à parte, que beira a universalidade de um modo único de expressão:

\footnotetext{
os resultados das pesquisas científicas são, aparentemente, válidos em todas as línguas (...) A ciência, sensu stricto, tal qual a conhecemos no ocidente desde o Renascimento, equivale, deste ponto de vista, ao aparecimento de uma nova língua. Nela, os dados brutos se realizam em símbolos matemáticos. Os intelectos nela pensam em símbolos matemáticos. Por ser uma língua recente, ela ilustra admiravelmente como a língua em geral funciona. ${ }^{11}$
}

A ciência, ainda em suas palavras, "longe de ser válida para todas as línguas, é ela própria uma língua a ser traduzida para as demais a fim de realizar-se nelas"12. Tal realização nas outras línguas encontra-se em andamento na equalização da escrita promovida pelo universo digital, ideia que será aprofundada nos capítulos da segunda parte desta tese. Por ora, 0 importante é notar que a ciência, como língua, se estrutura por meio da lógica e da matemática, diz o autor, e aí está o perigo: "o método lógico-matemático ultrapassa a poesia sem nada

\footnotetext{
${ }^{9}$ FLUSSER, Filosofia da caixa preta, op. cit, p.17.

${ }^{10}$ Idem. Língua e realidade. São Paulo: Annablume, 2007.

${ }^{11}$ Idem, p. 54.

${ }^{12}$ Idem.
} 
apreender ou compreender dela", pois, "compenetrado como está do aspecto formal e estrutural da língua, o intelecto lógico é incapaz de descobrir-lhe o aspecto poético"13. Poesia é algo extremamente caro ao filósofo no entendimento das relações entre língua e realidade, porque é a instância da língua que detém o poder criador de realidade. Por isto caberia às imagens técnicas o propósito de "remagicizar" textos: elas representam a possibilidade da poesia imbricada numa língua que se estrutura de forma lógico-matemática.

Vê-se que essa concepção de linguagem nada tem a ver com a tentativa de se emprestar o sistema da linguística como modelo, que se baseia na palavra e na escrita, como pretende a semiologia. Trata-se de revelar o próprio sistema fotográfico como uma evolução do sistema da linguagem, isto é, uma linguagem ontologicamente distinta da palavra e da escrita, mas que é também passível de ser articulada para criar realidades.

Tomando-se estas premissas dos dois textos flusserianos, pode-se enquadrar a fotografia dentro dos seguintes termos: sua estrutura tecnológica é mecanismo fruto da ciência como linguagem universal e, por se tratar da materialização de uma simbologia cientifica, suas imagens inevitavelmente simbolizam conceitos e teorias. 0 mundo representado na fotografia é 0 mundo objetivado pelo homem cartesiano- onde imagens fotográficas modelam a realidade em função de ações racionais, coordenadas e controladas-, mas que agora poderá ser submetido à nova aproximação: "a nova magia da imagem técnica não visa modificar o mundo lá fora, mas os nossos conceitos em relação ao mundo"14 .

A presença simbólica da ciência na imagem fotográfica a reforça como tecnologia: a fotografia já nasce com a indissociabilidade entre teoria e técnica, entre logos e techné. Ela tende a ser representação direta das alterações do fazer humano ante o conhecimento adquirido, incrementando o que Flusser entende como um cenário pós-industrial, em que a informação se sobrepõe ao objeto. A fotografia não seria mais um instrumento da era industrial, pois o que ela produz não é matéria, não modifica diretamente o mundo, mas indiretamente, por meio de símbolos. Essa categoria de aparato é denominada por Flusser de aparelho.

"Aparelhos não trabalham" e "sua intenção visa a modificar a vida dos homens". Tratase de uma nova categoria de trabalho em que o homem apenas "informa"15. Ora, dentro deste mapa que Flusser apresenta, não caberia afirmar que, no caso da fotografia, como foi insistido

\footnotetext{
${ }^{13}$ Idem, p. 158.

${ }^{14}$ Idem, p. 16.

${ }^{15}$ Idem, pp.19-28.
} 
nos primeiros capítulos, tal caráter "pós" não teria sido encoberto na trajetória tecnológica até antes do digital? Em outras palavras, não teria sido a fotografia muito mais assimilada como instrumento de uma era industrial ao invés de aparelho pós-industrial? Pois se foi assimilada como instrumento, o fazer humano se concentrou num engajamento pela máquina, e não pelas potencialidades desta nova categoria de trabalho.

Pode-se ainda encontrar em Flusser mais subsídios para respaldar esta hipótese, sobretudo no desenvolvimento de um termo bastante caro para a compreensão de seu pensamento: o programa. Um fotógrafo, na perspectiva de Flusser, ao exercer tal atividade de nova ordem, busca desenvolver as potencialidades "inscritas" no aparelho, sendo que "o mundo lá fora" só interessa nesse sentido. Decorre que a partir desta postura, vê-se a ação programada pelo aparelho, e não pela vivência no mundo. 0 que caracteriza 0 aparelho fotográfico é estar programado, as imagens estariam "pré-inscritas": "o fotógrafo age em prol do esgotamento do programa e em prol da realização do universo fotográfico"16. A potencialidade do aparelho para modificar os conceitos de mundo não é exercida de forma consciente, pois nessa relação que visa somente a esgotar o programa, que é o mesmo que fotografar o fotografável (o que está programado e pré-inscrito), o fotógrafo "penetra o aparelho a fim de descobrir-lhe as manhas", tornando-se funcionário dele:

\footnotetext{
Para funcionar, o aparelho precisa de programa rico. Se fosse pobre, o funcionário o esgotaria, e isto seria o fim do jogo. As potencialidades contidas no programa devem exceder a capacidade do funcionário para esgotá-las. A competência do aparelho deve ser superior à competência do funcionário. A competência do aparelho fotográfico deve ser superior em números de fotografias à competência do fotógrafo que o manipula. Em outros termos: a competência do fotógrafo deve ser apenas parte da competência do aparelho. De maneira que o programa do aparelho deve ser impenetrável para o fotógrafo, em sua totalidade. ${ }^{17}$
}

0 autor segue afirmando que "na procura de potencialidades escondidas no programa do aparelho, o fotógrafo nele se perde". Esse sistema complexo que é o amálgama entre funcionário e aparelho é a própria caixa preta de Flusser, onde o fotógrafo só pode dominar 0 input e o output desse complexo.

\footnotetext{
${ }^{16}$ Idem, p. 23

${ }^{17}$ Idem, p. 24.
} 
Mas essa perspectiva do filósofo leva a crer que não há possibilidade de atuação livre perante os aparelhos. Em especial quando considera que uma tecnologia mais fácil e acessível torna a caixa preta cada vez mais indecifrável e inacessível ${ }^{18}$ : quanto mais se aprimora uma caixa preta, mais difícil seria compreendê-la. Ora, estas questões tornam-se ainda mais dramáticas quando se percebe que no universo digital esse encobrimento da ação humana parece se dar de forma vertiginosa. Os aparelhos estão cada vez mais automatizados, assim como a palavra programa passa a ser assumida socialmente de forma corriqueira e enraizada, mesmo que utilizada numa dimensão que não condiz exatamente com o termo de Flusser, mas que não deixa de representá-lo em muitos aspectos.

"Não será negando a automaticidade dos aparelhos, mas encarando-a, que podemos esperar a retomada do poder sobre os aparelhos". Mas isto posto, qual seria a estratégia para esse confronto, tendo em vista que os aparelhos possuem programas inesgotáveis? Como tornar presente o fator humano na tecnologia se esta mesma tecnologia programa as intenções e as ações do homem?

Resposta: percepção de que tudo se trata de um jogo. No glossário que acompanha a sua obra, nota-se que aparelho é "brinquedo que simula um tipo de pensamento". Conscientizarse sobre o problema é conscientizar-se sobre a brincadeira, isto porque "os programas dos aparelhos permitem a introdução de elementos humanos não previstos". ${ }^{19}$

Um breve parêntese de reflexão: faz sentido considerar-se a imprevisibilidade como método para uma ação contra o aparelho fotográfico. Esses, frutos da evolução científica, se estruturam pela razão dentro daquele ambiente lógico-matemático já apontado. Razão é o inverso da imprevisibilidade, pois serve para estipular os próximos passos dentro de uma certa previsibilidade, de forma a garantir a sobrevivência humana. Ciência e razão são, portanto, frutos do medo. Quando se introduz algo imprevisto em qualquer setor que seja lógico e matematicamente organizado, cria-se a possibilidade do novo.

Entretanto, mesmo que os programas permitam essa possibilidade do novo, não seriam todos os fotógrafos que agiriam nesse sentido: "os fotógrafos são inconscientes de sua práxis", diz o filósofo. Para ele, a exceção são os fotógrafos experimentais:

\footnotetext{
${ }^{18}$ FLUSSER, Vilém. 0 instrumento do fotógrafo ou o fotógrafo do instrumento?. Revista Iris, São Paulo, agosto de 1982.

${ }^{19}$ Idem, p. 75.
} 
(...) estes sabem do que se trata. Sabem que os problemas a resolver são os da imagem, do aparelho, do programa e da informação. Tentam, conscientemente, obrigar o aparelho a produzir imagem nformativa que não está em seu progarma. Sabem que sua práxis é estratégia dirigida contra o aparelho. ${ }^{20}$

Por fim, vale ressaltar uma passagem do autor bastante cara a esta tese: "a revolução pós-industrial, tal como se manifesta pela primeira vez no aparelho fotográfico, passou despercebida pelos fotógrafos e pela maioria dos críticos de fotografia"21. Deve-se adequar a tese aos termos de Flusser: a tecnologia da fotografia, pós-industrial, foi absorvida como instrumento industrial ao longo de quase todo o século XX, mas agora, imersa no universo digital, esse caráter "pós" se revela. Mas de que forma considerar o universo digital como capaz de permitir tal conscientização do caráter da fotografia, se a tecnologia contemporânea representa 0 que há de mais sofisticado para aprimorar o escurecimento da caixa preta?

A resposta da questão se dará pela constatação de que o universo digital facilita o jogo, possui ares de brincadeira. $E$ isto significa que a possibilidade de uma atuação mais consciente perante 0 aparelho fotográfico pode não mais ser exclusividade dos fotógrafos experimentais de Flusser, principalmente se essa ideia de experimental for associada ao domínio tecnológico, que é cada vez menos necessário.

Mais à frente, este mapeamento encontrado na Filosofia da caixa preta será aprimorado em seu livro seguinte, 0 universo das imagens técnicas: elogio da superficialidade ${ }^{22}$. Este aprimoramento ganha mais evidência pela constatação dos aspectos da imagem digital e de suas reverberações na prática fotográfica, tema que será explorado ao longo da segunda parte que se inicia no próximo capítulo.

Cabe, portanto, retomar de forma sintética as perspectivas de reflexão que foram desenvolvidas até aqui.

As sutilezas que distinguem técnica de tecnologia foram primeiramente desenvolvidas, notadamente por serem ponto de partida originado de um universo mais prático de envolvimento com a fotografia, reflexo do fato de o autor ser fotógrafo profissional. Necessário foi localizar em seguida essas sutilezas na trajetória tecnológica da fotografia, cabendo ressaltar as anotações

\footnotetext{
${ }^{20}$ Idem, p. 76.

${ }^{21}$ Idem, p.75.

${ }^{22}$ Idem. $O$ universo das imagens técnicas: elogio da superficialidade. São Paulo: Annablume, 2008.
} 
sobre a desmaterialização do suporte fotográfico e a miniaturização dos equipamentos correspondentes. Propôs-se, assim, duas possibilidades de relação com a tecnologia que também se refletia na instrumentalização da imagem: uma, aflitiva, que criaria a ideia de uma "boa fotografia" sustentada pelo domínio tecnológico; outra, afetiva, que enxergaria no despojamento da técnica a possibilidade sempre presente de trato com a imagem numa perspectiva mais fluida e branda. Mas, de forma geral, os reflexos dessa trajetória tecnológica definiram a flexibilidade pragmática da fotografia, o que muito colaborou para a sua fragmentação em gêneros, que mais parecem confundir o específico fotográfico do que adentrar em seu significado social abrangente. A trajetória do pensamento de Barthes foi exemplo de que muito se teria falado de fotografias, mas antes de se falar sobre fotografia; mais ainda, como foi assimilada inicialmente como ferramenta tecnológica a serviço das artes, o caráter próprio da fotografia foi sendo definido dentro de uma tradição "pictórica" de relação com a imagem. 0 objetivo de definir a fotografia tendo em vista a distinção ontológica entre imagens fotográficas (imagens técnicas) e imagens tradicionais, foi possível a partir do pensamento de Vilém Flusser. A partir deste mapeamento proposto pelo filósofo, o esperado é que a fotografia, agora imersa num universo tecnológico mais aprimorado e automatizado, encontre sua instrumentalização dentro de uma perspectiva mais própria de uso e significado. 


\section{PARTE II}

A FOTOGRAFIA DO 1 AO 0 


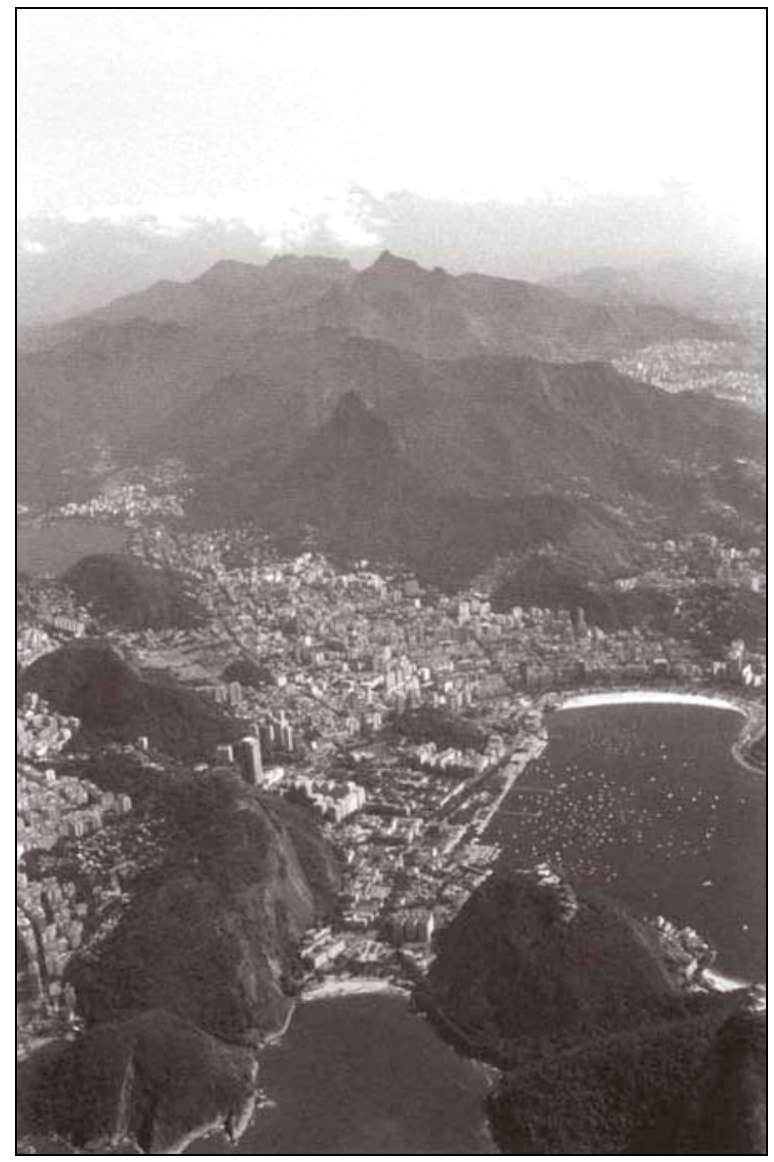

Fig. 21: Fotografia de Rosângela Rennó no âmbito do trabalho "A última foto", de 2006. 
Este capítulo não aborda ainda a fotografia digital especificamente. Ele é mais um elemento de transição entre a trajetória fotográfica do zero ao um (1ª parte desta tese), e esta trajetória rumo ao zero que se inicia. Por isto, antes de adentrar nas especificidades tecnológicas do digital, propõe-se aqui, por meio das considerações a seguir, sistematizar o teor dos questionamentos que já foram redigidos e, ao mesmo tempo, criar a ambiência necessária para avançar nas reflexões. A fotografia da página anterior é emblemática para isso, como poderá ser facilmente constatado no decorrer do texto.

Quando foi analisada toda a carga simbólica científica já presente na tecnologia da fotografia, foi atribuída à sua práxis uma valoração que ultrapassa uma flexibilidade pragmática calcada na sua apreensão como mero instrumento, que serve tanto aos componentes mais subjetivos das artes, quanto aos compontentes mais objetivos da documentação em geral (jornalismo, ciências positivistas, etc.). Afirmou-se que tal forma de apropriação é reflexo de postura moderna que passaria, ainda que sutilmente,a definir arte e ciência como duas esferas distintas.

Na verdade, seria dentro de um nicho estruturado pela conjunção dessas duas instâncias que o constitutivo do universo fotográfico parece melhor se adequar. E não se trata de buscar tal nicho para a fotografia em meio às diversas esferas da sociedade, mas perceber que a fotografia promove essa possibilidade onde quer que ela seja utilizada. Olhar uma fotografia como imagem técnica é olhar para a incongruência desse projeto da modernidade que separou arte e ciência em vias distintas.

Flusser foi apontado como quem precisamente definiu o peso da tecnologia fotográfica: ela vai muito além do que meramente seduzir o sujeito como possibilidade de consumo, e o filósofo busca promover o debate sobre a sua influência no modo de operar o aparato. Assume duas possibilidades frente ao aparelho: funcionário e fotógrafo experimental.

$\mathrm{Na}$ primeira, propõe que nessa relação tecnologia-sujeito-imagem, a articulação de valores e conceitos é delineada e imposta pela onipresença tecnológica. Assume que o aparelho, verdadeira caixa preta, induz o sujeito, o fotógrafo amador ou não, a operá-lo de uma forma programada, refletindo num movimento homogêneo de construção de imagens técnicas pelo mundo. Nesse momento, para o autor, quem vê álbum de fotógrafo amador vê as imagens produzidas por um mero funcionário incapaz de criar de maneira liberta dessa disciplina tecnológica, já que as superfícies simbólicas produzidas estão, de alguma forma, já inscritas 
(programadas, pré-escritas) por aqueles que produziram o aparelho. ${ }^{1} \mathrm{Na}$ segunda possibilidade, uma atuação livre perante o aparelho, e o fotógrafo experimental, ainda que desenvolvido de modo tímido em sua obra, apontaria para uma forma de prática capaz de questionar a imposição do programa.

$\mathrm{Na}$ análise da primeira perspectiva, Arlindo Machado questiona essa possibilidade finita de criação e encara justamente esse ponto da argumentação de Flusser como sendo passivel de críticas, reconhecendo, portanto, as possibilidades de criação como sendo possivelmente infinitas, uma vez que é algo difícil de se enumerar empiricamente. Dessa forma, a caixa preta de Flusser poderia ainda permitir possibilidades criativas legítimas, capazes de questionar uma imposição tecnocrática:

\begin{abstract}
0 grande problema de toda a argumentação de Flusser é que ele concebe as potencialidades inscritas nos aparelhos e seus programas como sendo finitas: elas são amplas, mas limitadas em número. Isso quer dizer que, mais cedo ou mais tarde, com a ampliação de suas realizações, as possibilidades de uma máquina semiótica acabarão por ser esgotadas. Ora, que há limites de manipulabilidade em toda máquina ou processo técnico é algo de que só podemos fazer uma constatação teórica, pois na prática esses limites estão em contínua expansão.²
\end{abstract}

Porém, Machado ressalta que, para Flusser, "mais cedo ou mais tarde, o universo tecnológico acabará por incorporar as descobertas e os desvios dos artistas para os seus fins programados". Mas o que seria trabalhar contra o programa ou, como assegura Flusser, obrigar 0 aparelho a produzir imagem que não está em seu programa? 0 que seria uma atuação como fotógrafo experimenta?

Machado sugere um caminho baseado na subversão da função do aparelho: para ele, "0 que faz um verdadeiro criador, em vez de submeter-se simplesmente a um certo número de possibilidades impostas pelo aparato técnico, é subverter continuamente a função da máquina de que ele se utiliza". Sugere, então, que a lógica instrumental do aparelho seja deslocada de sua produtividade programada, e que suas funções e finalidades sejam reinventadas, onde esse tipo de atuação seria "um dos papéis mais importantes da arte numa sociedade tecnocrática" 3 .

Sob tal perspectiva, cita artistas que subvertem a tecnologia do aparelho: Nam June Paik desvia o fluxo de elétrons no tubo da televisão com a ajuda de ímãs; Frederic Fontenoy e Andrew

\footnotetext{
${ }^{1}$ Idem. Filosofia da caixa preta, op. cit., p. 29.

${ }^{2}$ MACHADO, Arlindo. Repensando Flusser e as imagens técnicas. Disponível em http://www.fotoplus.com/flusser/vftxt/vfmag/ vfmag002.htm]. Acesso em 21/3/2007.

${ }^{3}$ Idem. Arte e mídia. Rio de Janeiro: Jorge Zahar, 2007, pp. 13-15.
} 
Davidhazy modificam o mecanismo do obturador da câmera fotográfica, e William Gibson insere um vírus em seu romance digital. São exemplos de criação sustentados pelo desvio técnico do aparelho utilizado, e desta forma, como elucida o autor, "não se pode dizer que esses artistas estão operando dentro das possibilidades programadas e previsíveis dos meios invocados". 4

Sim, é evidente que tais artistas não estão trabalhando dentro das possibilidades previsíveis, mas, tomando a pequena margem de manobra que dá Flusser, com os conceitos de aparelho e programa, seriam tais intervenções uma maneira convincente de ação da arte como questionadora de uma sociedade tecnocrática?

Deve-se levar em consideração que subverter o aparelho num nível técnico, de modo a possibilitar uma criação artística autêntica, não significa necessariamente adotar uma visão crítica sobre uma sociedade tecnocrática. Muito pelo contrário, pode significar também uma forma de submissão às doutrinas do aparelho. Empreender uma criação a partir de intervenções meramente de ordens tecnológicas sobre 0 aparelho sugere um ponto contraditório: se para atingir a obra, os mecanismos do aparelho devem ser alterados e, às vezes quase "destruídos" (ver o caso do obturador de Frederic Fontenoy e Andrew Davidhazy), não há sentido em falar que a criação é legítima a partir do aparelho, pois este já não é mais aquilo tal como projetado. A criação surge esquivando-se da tecnologia: esta é afirmada, reforçada e ressaltada pela necessidade que 0 artista tem de fugir de sua estrutura original. 0 artista admite a imposição da tecnologia e decide destruí-la. 0 fato é que esta postura, essa opção por "enfrentar" a tecnologia "destruindo-a", acaba por despertar suspeitas sobre a legitimidade da obra: uma vez destruído o aparelho, não se têm mais referências para julgar o produto, pois esse produto surge a partir de um "outro aparelho", criado pela intervenção técnica do artista, mas que não se coloca ainda como um aparelho inserido como uma prática cultural e, portanto, foge da esfera que o legitimaria como um ponto a ser questionado. E a tecnocracia se impõe sutilmente como delineadora da criação do artista que, por sua vez, acredita estar questionando a sociedade tecnocrática.

Talvez o aparelho deva ser encarado com todo o seu programa embutido, e este é que deve ser alterado. Se é desejável encontrar novas possibilidades de criação para a fotografia, parece ser muito mais legítimo subverter seu uso pelo programa, o que implica, inevitavelmente, a revisão da conduta de quem usa o aparato, mas assumindo-o, e não "destruindo-o". Tal parece ser a perspectiva de atuação de um fotógrafo experimental.

${ }^{4}$ Idem. 
Vários são os artistas brasileiros que buscam atuar por meio da fotografia, fazendo uso do potencial figurativo de seu mecanismo, e que poderiam ser enquadrados na ideia de fotógrafo experimental de Flusser. Arthur Omar, Vik Muniz, Miguel Rio Branco, dentre inúmeros outros, poderiam figurar como autores que buscam extrapolar a objetividade fotográfica, evitando assim, meras reproduções técnicas do mundo, incrementando o repertório visual para reconfigurar os estatutos de percepção instituídos pelas imagens técnicas. Em outras palavras, são fotógrafos que produzem informação não programada pelo aparelho fotográfico. Mas nenhum deles, se é que é possível afirmar desta maneira, atua de forma tão radical quanto Rosângela Rennó (Belo Horizonte, 1962).

"Gosto de ter a consciência de ser perversa com o código fotográfico (... $)^{5 "}$ : assertiva de Rennó que denuncia sua relação com a fotografia. E a maior perversão de Rennó consiste justamente em desenvolver trabalhos com fotografia sem a necessidade de fotografar. Como já afirmou Arlindo Machado, "ela apenas recoloca em circulação as fotos já existentes, sobretudo aquelas que foram descartadas pelo fluxo interminável de imagens industriais no mercado de massa", e com essa postura, Rennó busca atuar tendo não só fotografias como matéria-prima, mas seus aspectos simbólicos mais consagrados e determinados.

Todavia a postura "antifotógrafa" da artista, apesar de caracterizar a maioria de sua obra, não é radical. "Fotografo sim, quando é necessário, embora, na maioria das vezes, não seja" ${ }^{7}$, já afirmara em certa ocasião, o que obriga todos a olharem com mais atenção os momentos em que existe, para a artista, a necessidade de produção de imagem. Num desses momentos, e dentre os trabalhos mais recentes, figura "A última foto".

0 principal intuito desse seu trabalho foi de extrema consonância com o estudo que aqui é proposto: discutir essa possível revolução na história da fotografia, que consiste justamente na transição do sistema de filmes para o sistema digital. A proposta consistiu em convidar quarenta e dois fotógrafos ${ }^{8}$ para a produção de imagens com câmeras tradicionais pertencentes à coleção particular da artista.

\footnotetext{
${ }^{5}$ RENNÓ, Rosângela. Rosângela Rennó. São Paulo: Edusp, 1997.

${ }^{6}$ MACHADO, A fotografia como expressão do conceito, op. cit.

7 RENNÓ, R. (2007). Bate-papo (chat) com a artista ocorrido em 17/5/2007. Disponível em: http://tc.batepapo.uol.com.br/convidados/arquivo/arte/ult1739u111.jhtm. Acesso em junho de 2007.

8 Os fotógrafos que participaram do projeto, além da própria Rosângela Rennó, foram Antonio Augusto Fontes, Cláudia Tavares, Cris Bierrenbach, Cristiana Miranda, Caroline Valansi, Dani Soter, Daniel Martins, Deborah Engel, Debora 70, Denise Cathilina, Deise Lane, Ding Musa, Eder Chiodetto, Edouard Fraipont, Eduardo Brandão, luri Frigoletto, João Castilho, José Roberto Lobato, Luiz Garrido, Milan, Marcelo Tabach, Matheus Rocha Pitta, Milton Guran, Nino Andrés, Odires Mlászho, Otávio Schipper, Patricia Gouvêa,
} 
0 motivo escolhido foi o Cristo Redentor, monumento da cidade do Rio de Janeiro, que na época encontrava-se em meio a uma grande discussão a respeito dos modos como a sua imagem vinha sendo utilizada em diversas esferas, e mais, sobre a quem pertenciam seus direitos de imagem e reprodução. Rennó expôs dípticos com as imagens de cada fotógrafo juntamente com a câmera utilizada, agora lacrada com tinta preta. A artista também participou como fotógrafa, resultando num total de quarenta e três dípticos.
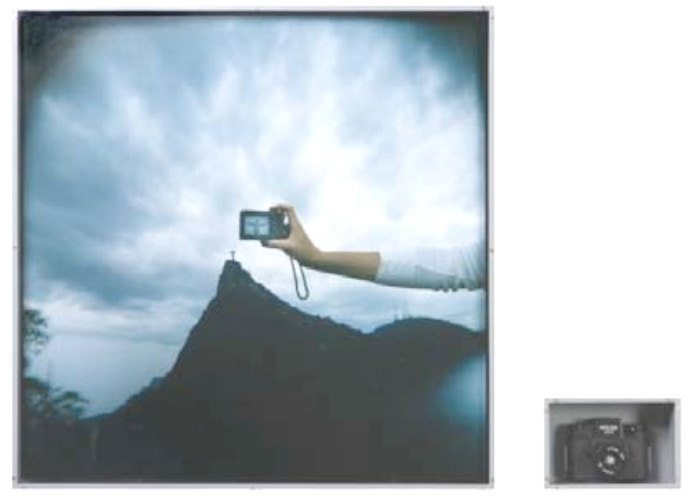

Fig. 22: Eduardo Brandão, Holga 120. Fotografia em cor e câmera fotográfica Holga $120 \mathrm{~S}$ emolduradas (díptico).

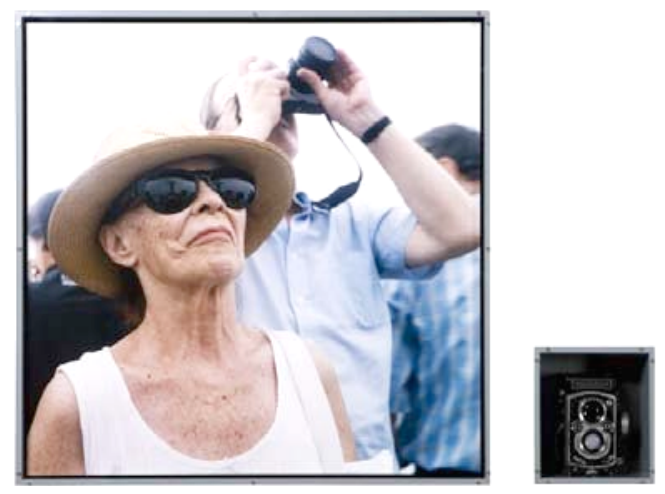

Fig. 23: Zé Lobato, Rolleiflex. Fotografia em cor e câmera fotográfica Rolleiflex Automat 4 emolduradas (díptico).

Como forma de aprofundar a questão, o catálogo da exposição ${ }^{9}$ traz o depoimento de diversos nomes expressivos das áreas da arte, comunicação e filosofia, tais como Régis Durand, Paulo Herkenhoff, André Parente, Milton Guran e Thomas Farkas, a respeito dos reflexos do processo evolutivo da tecnologia da fotografia neste momento de transição estrutural de sua prática. Dentre os temas tomados como eixos de discussão estão a relação entre imagem, memória e história na era digital, o reposicionamento da fotografia como disciplina, e a extinção do estatuto icônico-indicial das imagens. Por isso a escolha do Cristo Redentor como motivo é emblemética: sua posição simbólica perante a cidade, a igreja e o indivíduo, evidenciada pelas questões a respeito dos direitos de imagem que o circundaram na época, mediadas pela

Paula Trope, Pedro Vasquez, Pedro David, Pedro Motta, Rafael Assef, Rochelle Costi, Ruth Lifschits, Rogério Reis, Thiago Barros, Vicente de Mello, Walter Mesquita, Wilton Montenegro, Ynaiê Dawson, Walter Carvalho e Zeca Linhares. A exposição foi realizada na Galeria Vermelho, em São Paulo, em outubro de 2006.

${ }^{9}$ RENNÓ, Rosângela. A última foto. São Paulo: Galeria Vermelho, 2006. 
fotografia num momento em que justamente se revisa o papel efetivo da imagem contemporânea na manutenção da cultura.

0 fato é que todas as quarenta e duas imagens do Cristo Redentor, produzidas pelos fotógrafos convidados, carregam em si um certo apelo estético que sugere promover o debate entre as ideias da fotografia como arte e fotografia como documento. É notável, em muitas dessas fotografias, a busca por burlar a objetividade fotográfica por meio de tentativas de desenvolvimento de uma linguagem fotográfica, as quais se mostram tão evidentes que despertam certa desconfiança sobre a atitude ser programada ou não. Dentro dos termos flusserianos, pode-se dizer que algumas destas imagens demonstram a preocupação de uma atitude experimental, mas o resultado sugere mais a tentativa de afirmar a fotografia como forma de arte.

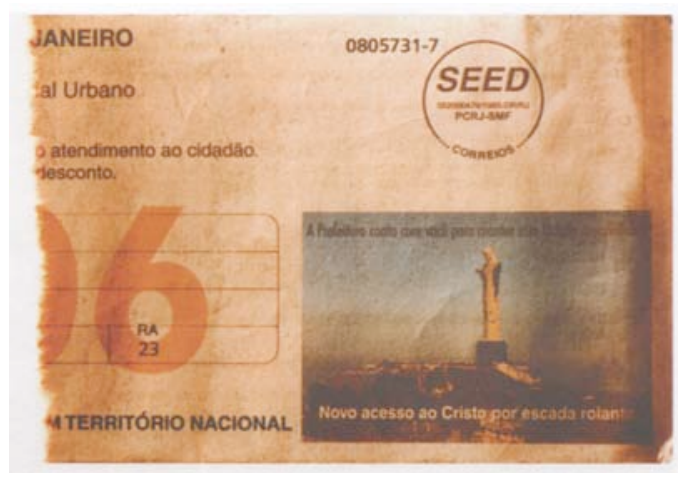

Fig. 24: Foto de Cristiana Miranda.

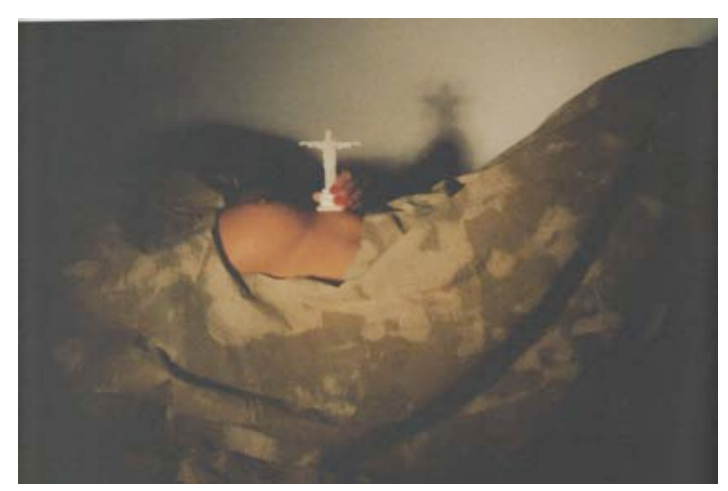

Fig. 26: Foto de Luiz Garrido.

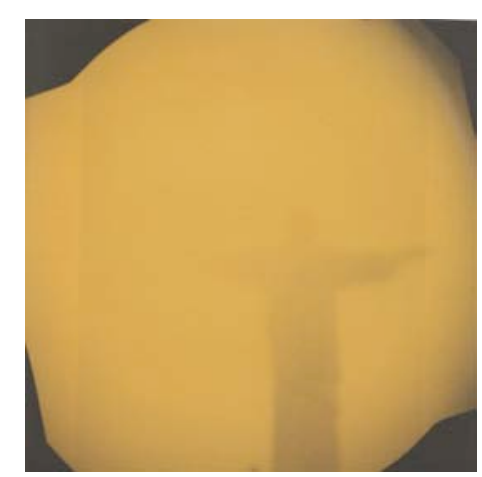

Fig. 25: Foto de Debora Hengel.

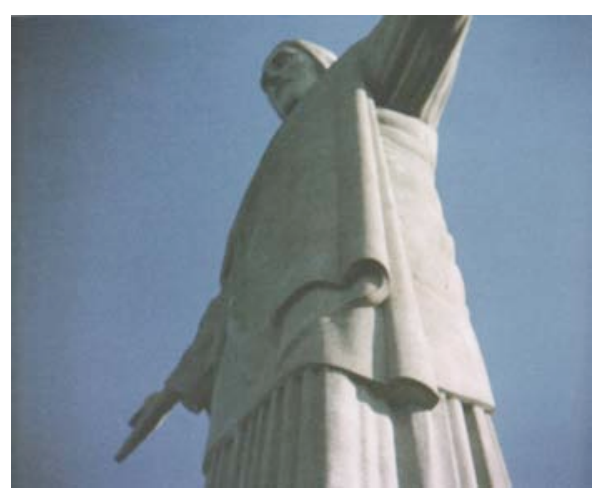

Fig. 27: Foto de Otávio Schipper.

Mas não é o caso da imagem de Rennó, a que foi destacada na abertura do capítulo. Sua fotografia parece ser a única assumidamente trabalhada dentro de uma produtividade programada, visto não apresentar qualquer distorção plástica, agindo dentro de um senso comum 
do que é a fotografia, além de não aparentar qualquer preocupação em criar uma obra de forma legítima e singular por meio de distorções de aspectos técnicos do aparelho. Simplesmente apontou a câmera para o motivo e disparou, tal como um funcionário do aparelho.

Mas é evidente que, por meio da imagem resultante, vê-se como especifica Flusser, um fotógrafo experimental, uma práxis conscientizada, uma atuação contra o programa, mesmo agindo dentro das opções impostas pela tecnologia do aparelho. 0 Cristo Redentor, ao contrário das quarenta e duas outras imagens, praticamente não aparece na imagem de Rennó, mas sim a razão de sua existência que é a própria cidade do Rio de Janeiro, minando toda a discussão em torno da questão sobre "a quem pertence a sua imagem"; ao mesmo tempo, questiona o valor icônico-indicial da fotografia, ao apresentar uma fotografia de um motivo, sem que este motivo apareça na própria imagem. Uma foto que traz muito mais do que uma mera representação técnica, e que aborda, de forma legítima, a proposta e os objetivos da obra: qual o valor da imagem do monumento? (ou, já no âmbito maior da proposta do trabalho em abordar a transição tecnológica da fotografia e seu estatuto documental, caberia a pergunta pelo valor de uma fotografia).

Quando se leva em conta a afirmação da artista sobre somente fotografar quando necessário, pode-se dizer que Rennó se posiciona não só em relação às discussões referentes à imagem do Cristo Redentor, mas também e principalmente, em relação às imagens produzidas pelos fotógrafos convidados. Foi necessário fotografar.

Em resumo: a imagem de Rennó sintoniza-se com o ideal de fotógrafo experimental de Flusser, pois, de forma contundente e convincente, atinge o objetivo proposto, e se destaca sem qualquer embate com a tecnologia do aparelho. Aceitar a tecnologia de forma consciente, fazendo uso de acordo com o "programado", permite que o seu deciframento por meio de sua práxis seja garantido e, desta forma, é também meio eficiente de se atuar de maneira questionadora numa sociedade tecnocrática.

Cabe também afirmar que sua imagem, ao abrir mão de evidências plásticas de intervenção que buscam burlar a objetividade da fotografia -que é justamente o que sustenta 0 grosso da produção das outras imagens- aponta para a questão do reposicionamento do indivíduo fotógrafo, profissional ou não, perante a fotografia. 0 vernaculismo de sua imagem vai contra as dos outros autores que evidentemente buscaram artifícios para alimentar o embate entre sujeito e objeto. Artifícios que supostamente sugerem novos olhares sobre o mundo e que 
fazem da fotografia instrumento para isso. Mas este mundo sempre estará objetivado numa imagem fotográfica, por mais que se tente buscar o contrário, assim como uma ideia moderna de fotografia como arte procura instituir. A imagem de Rennó assume esta objetividade: não há truques, distorções ou manipulações que a coloquem ao lado das quarenta e duas outras imagens "artísticas".

Em síntese: Rennó demonstra afeição com a técnica fotográfica, e os outros certa aflição em tentar burlar a sua objetividade; Rennó traz o significado da fotografia, os outros parecem trazer fotografias apenas.

É nesse sentido que sua última foto se torna a primeira desta segunda parte da tese: a evidência de sua imagem, de modo como parece ter questionado os processos criativos dos 42 fotógrafos, também deve servir como referência para a constatação de que tais processos criativos, agora imersos na era das imagens digitais, não podem se resumir a somente abarcar intervenções plásticas nas imagens brutas do mundo, principalmente neste momento em que tudo é facilitado ao extremo pelas tecnologias contemporâneas de produção e manipulação.

0 embate entre funcionário e fotógrafo experimental será incrementado pelo universo digital. Mas antes de dar prosseguimento a esse embate, necessário é apontar algumas considerações sobre a estrutura das imagens fotográficas digitais, tarefa para o próximo capítulo. 


\section{0 DIGITAL E A FOTOGRAFIA EM SISTEMA}

Muitas das abordagens teóricas que buscam falar sobre imagens digitais ou imagens numéricas não tratam necessariamente das especificidades da fotografia, uma vez que os processos de hibridação das mídias audiovisuais tornam-se cada vez mais lugares comuns (tema a ser retomado mais a frente). 0 que se encontra facilmente como bibliografia são manuais que trazem conceitos e termos tecnológicos, os quais permitem explorar a técnica fotográfica para garantir ao usuário comum o aprimoramento do manuseio das câmeras e softwares de manipulação. Mas o intuito destes manuais é mais estabelecer os modos de operação para se atingir resultados previsíveis, explorando ferramentas e efeitos plásticos já consagrados. Pouco se fala sobre os princípios mais elementares da constituição da imagem digital que, se bem assimilados, poderiam facilmente permitir ao usuário burlar os modos de usos já "enlatados" (ou "programados", para ficar nos termos de Flusser), e diversificar seus objetivos plásticos dentro de uma perspectiva mais livre de atuação. 
Nessa esfera mais elementar da estrutura da imagem digital está o cerne das motivações que originam discussões e reflexões a respeito das atribuições da imagem numérica. Vale lembrar o que foi afirmado anteriormente sobre a história tecnológica de a fotografia ser reflexo da história dos suportes da imagem: o mesmo ocorre no caso da fotografia digital. As reverberações dessa mudança para imagem numérica, refletida na tecnologia da câmera e nas possibilidades de sua apropriação, serão ressaltadas quando oportuno ao longo dos próximos capítulos. Já este capítulo pretende esmiuçar as especificidades tecnológicas da estrutura da imagem fotográfica digital somente, cabendo ressaltar que tal tarefa será realizada a partir de uma visão própria sobre o que deve ser eleito como efetivo e decisivo para o entendimento da constituição de uma fotografia numérica'.

Inicialmente, seguem-se alguns apontamentos sobre o significado do termo "digital" e suas implicações. Etimologicamente, o termo encontra suporte no latim digitus, em português, "dedo". Esta associação se deve ao fato de os dedos serem considerados o suporte mais simples para a realização de cálculos, pois trabalham com valores numéricos inteiros. 0 universo digital reduz qualquer informação a números simples, no caso, zeros e uns. Mas esses dois dígitos, na verdade, são representativos de valores discretos de tensão elétrica, porém contrastantes entre si, correspondendo, respectivamente, a níveis de baixa tensão (low) e alta tensão (high). Todo sinal elétrico pode ser convertido para sinal digital por meio de amostragens, e isto permitiu a simplificação dos circuitos elétricos, a sber, a criação de chips, (circuitos integrados), provocando toda a revolução tecnológica da microinformática. Aliados à tecnologia dos semicondutores, mesmo os chips passaram a ser cada vez menores e a comportar circuitos cada vez mais complexos, diminuindo drasticamente a materialidade necessária à estruturação de equipamentos diversos ${ }^{2}$.

$\mathrm{Na}$ fotografia digital, a luz proveniente da cena a ser registrada percorre o mesmo caminho da fotografia tradicional: atravessa a objetiva (agrupamento de lentes convergentes e divergentes, sempre de vidro e/ou acrílico), é modulada pelo diafragma (mecanismo que controla

\footnotetext{
${ }^{1}$ Necessário destacar que grande parte das informações a seguir foram obtidas pela leitura da obra Equipamento fotográfico: teoria e prática, de Thales Trigo (São Paulo: Senac, 2005). Trigo, físico e fotógrafo, traz importante contribuição no sentido de esgotar os fundamentos científicos da tecnologia da fotografia digital e tradicional.

${ }^{2} \mathrm{~A}$ evolução tecnológica recente na área já prevê um problema a curto prazo: o encolhimento dos transistores que estruturam os chips estão se aproximando dos limites da física fundamental. De tão pequenos, permitem o vazamento de elétrons, o que confunde o reconhecimento dos estados "high" e "low". "Atualmente, um típico processador de ponta da Intel se baseia em aproximadamente 1 bilhão de transistores ou mais, cada um capaz de ligar e desligar cerca de 300 bilhões de vezes por segundo, e colocados tão juntos que 2 milhões de transistores caberiam confortavelmente no ponto ao final desta frase." (Markoff, 2009).
} 
o diâmetro da circunferência do orifício para a entrada da luz, ou seja, controla a "abertura"), e ao atingir a superfície fotossensível permanece em contato com tais superfícies pelo tempo que 0 obturador permitir (onde se faz o ajuste de "velocidade") ${ }^{3}$. 0 que inicia a diferenciação entre fotografia digital e fotografia tradicional é justamente essa superfície fotossensível. Nas câmeras fotográficas tradicionais, a superfície fotossensível é composta por uma película transparente, com sais de prata que escurecem em contato com a luz; e nas câmeras fotográficas capazes de gerar uma imagem digital, essa superfície é composta por minúsculos componentes eletrônicos, os fotodiodos, capazes de gerar carga elétrica quando expostos à luz. Os fotodiodos são parte de um dispositivo de estrutura mais complexa, que é, na verdade, uma placa que ocupa o plano onde se formará a imagem que a câmera fotográfica apreende (plano focal). Os dois modelos mais utilizados são o CCD (charged-coupled device) e o CMOS (complementary metal-oxide semiconductor), e ambos funcionam de forma similar. Assim como o escurecimento dos sais de prata depende da intensidade luminosa, essa carga elétrica é gerada com intensidades distintas em função da variação da intensidade da luz que ali chega. No caso do CCD, o dispositivo até agora mais utilizado, a carga elétrica é gerada analogamente a partir das ondas luminosas, para só depois ser convertida para informação digital. Istoo significa que toda fotografia digital obtida por meio de CCD, é, primeiramente, analógica (daí a insistência neste estudo em falar de fotografia tradicional, e não fotografia analógica).

Essa conversão da carga elétrica em informação digital (conversão $A / D$ ) nada mais é do que a tradução dos valores dos sinais elétricos em códigos compostos pelo agrupamento de apenas dois dígitos, os bits 1 e 0 , que, na realidade, significam "sim" ou "não" em relação à existência de informação elétrica discreta (low e high $)^{4}$. Por exemplo: suponham-se sinais elétricos que variam de 0 voltz a 10 voltz a serem convertidos para informação digital. Um conversor A/D, que gera informação de 8 bits ( 1 byte), atribuiria a informação 00000000 para 0 voltz (sinal mínimo), e 11111111 para 10 voltz (sinal máximo). Outros valores compreendidos entre 0 voltz e 10 voltz possuiriam combinações distintas de 8 bits. Quanto mais bits 0 equipamento utilizado for capaz de gerar (por exemplo, 12 ou 16 bits), mais precisa é a indicação das variações da carga elétrica, o que, no caso da fotografia, mais precisa é a informação luminosa.

\footnotetext{
${ }^{3}$ Cabe lembrar que o obturador pode estar antes ou depois do diafragma, conforme já apontado no capítulo 2.

${ }^{4}$ No caso do CCD, essa conversão é realizada num conversor A/D após o transporte das cargas elétricas; no caso do CMOS, essa conversão é realizada no próprio dispositivo.
} 
A superfície fotossensivel, portanto, gera sinais elétricos, e a intensidade do sinal se ajusta à intensidade luminosa. Quanto mais luz, maior o valor do sinal. Uma imagem totalmente escura, um negro absoluto, em nada excita os fotodiodos, não gerando sinais elétricos; uma imagem totalmente clara, branco absoluto, excita os fotodiodos no limite, gerando o sinal elétrico máximo. A luminância de uma imagem fotográfica digital corresponde à variação destes valores entre o escuro e o claro. As câmeras digitais são capazes de registrar 256 variações de luminância, o que é um pouco mais do que o olho humano é capaz de perceber. Isto quer dizer que a informação digital 11111111 corresponde ao $255^{\circ}$ tom, enquanto a informação digital 00000000 corresponde ao tom mais escuro. Entre o negro e o branco absolutos temos 256 tons diferentes de intensidade luminosa, que podem ser registrados por uma câmera fotográfica digital.

Cada fotodiodo, após a conversão A/D, gera a informação denominada pixel (picture element). Um pixel totalmente branco traz 1 byte ( 8 bits) composto somente por 1; um pixel totalmente escuro não traz informação, é 1 byte composto somente por 0 . É pelo agrupamento de milhões de pixels que uma imagem fotográfica digital pode ser vista. Como um pixel é gerado a partir de uma referência fisicamente fixa, o fotodiodo na placa fotossensível, cada pixel possui sua coordenada de localização. Uma câmera de 12 Mpixels, por exemplo, é, na verdade, uma câmera fotográfica com uma superfície fotossensível que traz 12 milhões de fotodiodos capazes de gerar um pixel cada um. Cada pixel dessa câmera tem uma informação luminosa que pode variar dentro dos 256 tons já apontados e ocupa um local exato dentro da estrutura da imagem digital. Essa luminância e este local exato podem ser mapeados por softwares específicos para manipulação de imagens digitais (o que será explorado oportunamente).

Mas cada pixel não gera somente imagens em preto e branco. Cada fotodiodo possui filtragem para uma das cores primárias do sistema RGB (Red, Green, Blue), ou seja, vermelho, verde e azul. A partir destas três cores é possível compor todas as outras cores do espectro visível. Quando uma determinada intensidade luminosa excita um fotodiodo, ela já o faz indicando a preponderância de sua cor. Cada pixel produzido é capaz de gerar uma cor a partir do sistema RGB. Portanto, todo pixel, certamente, traz um valor de intensidade luminosa entre 0 e 255 para cada canal de cor. Um pixel de um céu azul, por exemplo, possui a deficiência de vermelho e verde; um pixel de uma folha de árvore apresentará uma valor de verde mais alto do que vermelho e azul; uma gota de sangue trará pixels com a preponderância de vermelho em relação 
às outras duas cores. Haverá, assim, a possibilidade de aproximadamente compor 16.000.000 de cores $(256 \times 256 \times 256)$.

Mas deve-se atentar para a efemiridade na formação das cores na fotografia digital. $\mathrm{Na}$ maioria das câmeras, cada pixel é capaz de colher informações para gerar somente uma das cores primárias ${ }^{5}$. Os dois outros canais de cor para cada pixel são gerados por aproximação, por algoritmos que calculam a preponderância das cores a partir do comportamento dos outros pixels. Quer dizer que cerca de $65 \%$ das cores de uma imagem fotográfica digital não são obtidas a partir da cena fotografada, e sim por meio de reposicionamento de zeros e uns. Deve-se somar a este jogo numérico o fato de que este cálculo na composição das cores pode variar em função de padrões industriais que foram sendo estruturados de acordo com as necessidades circunstanciais de empresas de tecnologia dos setores de produção gráfica, softwares e equipamentos audiovisuais. Hoje, estes padrões são mapeados e compõem um elenco de possibilidades de tratamento de cor para a imagem digital. Trata-se do perfil ICC (Internacional Color Consortium) de uma imagem, ou seja, aponta em qual padrão industrial de cor a imagem foi gerada. Quando a imagem digital circula de um suporte a outro, e existe a preocupação de que as cores sejam preservadas, deve-se buscar a conversão de seu perfil ICC para o mesmo perfil do suporte.

0 que se procurou demonstrar aqui, com todo esse "desfile" de discursos tecnológicos, é a volatilidade da imagem fotográfica digital. 0 pixel, a unidade dessas imagens, apesar de ser gerado por uma estrutura física (o fotodiodo), consiste apenas em bits, informação numérica. Não existe forma definida para um pixel. Na tela do computador, ele adquire um formato de uma imagem de um quadrado luminoso; já no papel, quando impresso, ele se torna um gota de tinta; num CD ou DVD, ele se transforma em sulcos: trata-se de um apanhado de informação binária que se atualiza nesses suportes. Pixel, objetivamente, não existe. Imagem fotográfica digital, objetivamente, não existe.

De verdadeira joia a ser possuída (a unicidade do daguerreótipo, o primeiro processo) à desvalorização completa de seu suporte, a fotografia foi encontrando, na evolução de sua tecnologia, a evidenciação de seu caráter pós-industrial: a informação, mais do que nunca, se sobrepõe ao objeto em sua configuração digital.

\footnotetext{
${ }^{5}$ Trata-se de um modelo de construção, o padrão Bayer, que, com o propósito de associar a sensibilidade do CCD à sensibilidade do olho humano, prioriza a filtragem para o verde, apresentando o dobro de pixels em relação ao vermelho e ao azul.
} 
Walter Benjamin cunhou o conceito de "aura" em A pequena história da fotografia tendo em vista, entre outros aspectos, o caráter de preciosidade de produção do daguerreótipo. E foi a partir deste conceito que o pensador elaborou suas reflexões sobre o potencial da reprodutibilidade técnica na politização da arte, dando lugar especial à fotografia e ao cinema neste processo ${ }^{7}$. Na reprodutibilidade técnica -que, segundo Benjamin, teria sido inaugurada verdadeiramente pela fotografia-, a transitoriedade substitui a durabilidade, corrompendo o "aqui e agora" da obra de arte, retirando-a de seu "invólucro", destruindo sua "autoridade".

Mas a fotografia foi capaz de criar sua própria "aura". Ela também se tornou obra de arte devido às suas especificidades técnicas. Ela também passaria a ter o seu "aqui e agora", assim como conseguiu construir a sua "autoridade", como se buscou já apontar. Porém, tal afirmação deve ser contestada no momento em que, definitivamente, sua estrutura como objeto é fragmentada no universo binário, momento em que a "transitoriedade" afirmada por Benjamin é exacerbada pelos fluxos de pixels incessantes.

Sintomático, por exemplo, o que ocorreu no processo de transição entre a fotografia tradicional e a fotografia digital no mercado fotográfico publicitário. Num determinado período (entre 1999 e 2001, aproximadamente), fotógrafos que já desenvolviam seus trabalhos com câmeras digitais eram obrigados também a imprimir uma transparência para certificar sua produção junto às agências e aos seus clientes. Apesar de ser totalmente inútil dentro do processo de produção gráfica de uma peça publicitária, essa película forjada garantia a valoração da unicidade da matriz fotográfica. Isto revela que a imagem fotográfica digital, devido à sua volatilidade, não foi inicialmente encarada como objeto suficientemente capaz de determinar sua própria valoração dentro dos mesmos moldes da fotografia tradicional com película. Resquícios de uma "aura" própria da fotografia. Hoje, no mercado publicitário, já quase não se admite fotografia que não seja digital ${ }^{8}$.

Esse processo de destruição da "aura" da fotografia ainda está em andamento. 0 fato de ainda de se separar a fotografia em digital e "analógica" (tomo aqui o termo do senso

\footnotetext{
6 "O próprio procedimento técnico levava o modelo a viver não ao sabor do instante, mas dentro dele; durante a longa duração da pose, eles por assim dizer cresciam dentro da imagem (...) tudo nessas primeiras imagens era feito para durar"; "havia um aura em torno deles, um meio que atravessado por seu ohar lhes dava uma sensação de plenitude e segurança"; "é à luz dessas centelhas que as primeiras fotografias, tão belas e inabordáveis, se destacam da escuridão que envolve os dias em que viveram os nossos avós" (BENJAMIN, op. cit., pp. 96-107).

${ }^{7}$ BENJAMIN, Walter A obra de arte na era de sua reprodutibilidade técnica. In: Magia e técnica, arte e politica: ensaios sobre literatura e história da cultura. São Paulo: Brasiliense, 1996, pp. 168-171.

${ }^{8}$ Dados obtidos a partir de conversa com Felipe Leme, diretor de arte da agência Talent, em São Paulo, em março de 2009.
} 
comum), é indício dessa transição. A fotografia nunca era denominada fotografia analógica até 0 surgimento da fotografia digital. A separação em dois momentos distintos é indício de rompimento, de que algo foi drasticamente alterado. Indica que o novo ainda é novo, e o velho ainda resiste e insiste.

Portanto, o zero e o um na fotografia não trazem somente o extremo de uma transitoriedade da imagem, pois não apontam unicamente a destruição da "aura" daquilo que está representado. Emprestam também a sua volatilidade à própria noção vigente do que a fotografia significa e significou.

As imagens numéricas carregam em si uma complexidade ímpar numa referência à sua estrutura, como foi aqui exposto de forma bastante sintética. 0 discurso tecnológico, portanto, foi aprimorado e torna-se cada vez mais inacessível para aquele que tem a câmera fotográfica digital apontada para uma paisagem ou um familiar. 0 paradoxo é evidente: à medida em que a tecnologia se torna mais e mais requintada, e, portanto, mais complexa e mais inacessível, as câmeras tornam-se mais automáticas e mais acessiveis, e os procedimentos para a obtenção de imagens exigem menos laboriosidade. 0 discurso tecnológico é estancado no aparelho fotográfico e ali cessa.

Apreendida a estrutura da imagem digital, torna-se mais fácil entender, também estruturalmente, o que significa manipulação digital da imagem fotográfica, ou, no jargão popular, o "tratamento da imagem". Pois o que o tratamento digital faz é simplesmente a alteração nos valores de $R, G$ e $B$ dos pixels da imagem, ou melhor, cada pixel pode ter os seus valores de luminosidade alterados dentro das 256 possibilidades de tons. Assim, no limite, cada pixel tem mais de 16 milhões de possibilidades. $E$ as possibilidades de recombinações, portanto, que sustentam as alterações de uma imagem, praticamente tenderiam ao infinito numa imagem digital composta por alguns milhões de pixels. Essa transmutação de valores pode significar desde um simples ajuste de contraste ou nitidez até a conversão da imagem para uma visualidade de uma pintura à oleo ou aquarela (passa-se de straight photographer para pictorialista, e vice-versa, num piscar de olhos, isto é, num simples "click").

Tais possibilidades são acessadas por meio de softwares que apresentam seus algoritmos desenvolvidos para a busca de determinados efeitos visuais. Qualquer algoritmo é uma 
"sequência de passos que visa a atingir um objetivo bem definido"9. Quando se intenta produzir qualquer alteração numa imagem, o software dispõe de seu algoritmo específico. Existem diversos softwares para o tratamento de imagens no mercado e, por conseguinte, formas distintas de produzir os mesmos efeitos plásticos. Essa distinção entre algoritmos é o que define a eficiência de atuação do software quanto à sua rapidez e à sua capacidade de lidar com os volumes de dados necessários para determinada manipulação. Softwares podem apresentar regras internas distintas para a execução de uma mesma tarefa. Portanto, existe no universo do tratamento digital de fotografias, um reconhecimento da capacidade de atuação do software que sempre tende a ser medida pela rapidez com que este trabalha e pela qualidade do efeito produzido.

Mas para deparar-se com este arsenal de possibilidades é preciso ter um objetivo visual em mente. E, muitas vezes, este objetivo já está definido no momento da tomada, onde este se torna apenas o primeiro passo dentro do processo, o que leva a pensar numa ideia de fotografia em sistema, ou seja, uma prática que se concretiza e se diversifica em etapas posteriores ao registro, mas ainda no âmbito da produção da imagem, e não da distribuição ou divulgação. 0 instantâneo fotográfico, o momento decisivo bressoniano ${ }^{10}$ prolonga-se eternamente no abismo das infinitas possibilidades de intervenção na imagem. 0 tratamento digital não é mais etapa posterior, ele está no início, ainda antes da tomada.

E aqui está aquilo que mais seduz, e ao mesmo tempo, mais reforça a resistência daqueles que ainda optam pela fotografia com filmes. Tomando a metáfora de que quem fotografa tem arma nas mãos, se antes o significado da fotografia se justificava pelo ato caçador, hoje ela se justifica mais pelo preparo da caça. A fotografia em seu formato digital, para os saudosistas, deixa, de certa forma, de ser a aventura da captura do inusitado, do flagrante de cenas únicas e memoráveis, uma prática somente para aqueles que possuíam "o olho", o olhar aguçado e comprometido com uma intuição única para a percepção singular do real, aspectos estes que nortearam a ideia de uma "boa fotografia", como se buscou evidenciar quando a hegemonia do fotojornalismo foi abordada anteriormente. Ora, mas se a caça legítima é aquela que tem o objetivo de alimentar as pessoas, não se pode negar que nunca houve tanta fartura: vive-se um banquete fotográfico na contemporaneidade. Quer-se dizer que a fotografia parece se justificar muito mais pelo seu potencial como "porto de criação", ou melhor, como "brincadeira", do que

${ }^{9}$ OLIVEIRA, Elaine Harada T. Introdução à lógica de programação. Disponível em http://www.dcc.ufam.edu.br. Acesso em dezembro de 2009.

${ }^{10}$ CARTIER-BRESSON, op. cit. 
pelo simples atestamento da realidade perante a câmera. A fotografia digital na tomada, a despeito de ser revelada imediatamente, é apenas ainda um projeto, até mais do que a imagem latente na fotografia tradicional. E toda fotografia digital, quando imersa na fase do tratamento, ganha novo espaço de diálogo com seu autor.

Trata-se de um interferência inédita no processo fotográfico que não pode ser enquadrado nos mesmos moldes dos processos fotoquímicos. Aqui tudo é realmente simulado e experimentado, e mesmo que seja executado, pode tornar-se novamente a matriz. Aqui 0 processo se sobrepõe à imagem, a imagem é imagem enquanto processo. Revela-se o jogo de tentativas e erros, mas os erros podem não ser consumados. Constatação que encontra reforço em Fabris quando afirma que a construção do imaginário caminha "em direção a uma estética de procedimentos na qual o processo se impõe sobre o objeto". ${ }^{11}$

É verdade que muito do que a manipulação digital permite hoje também era possível nos processos tradicionais, mas não com a mesma agilidade. Exemplo: qualquer ajuste de contraste numa imagem em papel preto e branco levava alguns minutos para ser efetivado e avaliado. Por meio de um ampliador, projetava-se o negativo numa folha de papel fotográfico ainda não exposta; tal folha era banhada por alguns segundos (cerca de 30) na química para revelação (revelador); o processo era então interrompido (banho de 1 minuto em ácido acético), para, por último, ser fixado (banho no fixador por cerca de 30 segundos). A partir daí era possível retirar a prova fotográfica do ambiente iluminado pela luz vermelha e avaliá-la em condições luminosas normais. Mas era ainda necessário lavar a cópia em água corrente por cerca de 5 minutos. Após a secagem (se em estufa alguns minutos, se em ambiente normal, algumas horas), a fotografia propriamente dita estava pronta. Vê-se que, tal como exemplificado aqui, era exigido um processo laborioso para um ajuste simples, e que nestes procedimentos técnicos, a experiência tecnestésica proporcionada centrava-se no trabalho, no discurso tecnológico impregnado, pois mesmo se o intuito era introduzir efeitos ou distorções, as etapas básicas deveriam ser primeiramente seguidas de forma a proporcionar parâmetros de avaliação.

E aqui cabe retomar Ansel Adams no sentido de evidenciar tais alterações. Em um de seus textos, o fotógrafo revela a sua prinicipal motivação para apresentar ao seu leitor suas técnicas para a obtenção de imagens fotográficas: Adams acreditava, e com razão, que o domínio

\footnotetext{
${ }^{11}$ FABRIS, Annateresa. Redefinindo o Conceito de Imagem. Revista Brasileira de História, São Paulo, v. 18, n. 35, 1998. Disponível em: http://www.scielo.br/. Acesso em: 19/3/2007.
} 
tecnológico representava forma contundente de "visualizar" a fotografia no momento do registro, onde saber prever o resultado imagético seria uma função a se atribuir ao seu "sistema de zonas". ${ }^{12}$ Dada a abrangência dessa técnica de Adams, conclui-se que, para o fotógrafo, fundamental era dominar todas as etapas do processo fotográfico, isto é, da medição da luz à impressão de uma cópia em papel, passando obviamente pela revelação do negativo.

Ora, mas não se trata aqui também de uma cadeia operacional que poderia ser enquadrada na ideia de fotografia em sistema? Num certo sentido, poder-se-ia afirmar que sim, mas com restrições, pois o grosso da cadeia operacional nesse caso se concentrava numa preocupação que hoje parece não mais existir: prever o que seria a imagem. Adams preocupavase com a qualidade e a nitidez de suas imagens, e seria fundamental prever o comportamento de suas unidades constituintes, a saber, os pontos, os "grãos", os sais de prata. Na fotografia em seu formato digital, cada unidade constituinte pode ser alterada, pois cada "ponto" tem a sua localização e luminância determinadas por números.

A partir do momento em que a fotografia passou a ser pré-visualizada, ou visualizada imediatamente após a tomada, pelos painéis de cristal líquido presentes na maioria das câmeras digitais, a necessidade de se recorrer a um conhecimento da tecnologia nos termos de Adams passaria a perder espaço. Não que a obra de Adams tenha perdido a sua validade: muito de seu conhecimento é o que permite explorar as ferramentas presentes nos aplicativos de manipulação, pois até na fotografia digital os profissionais ainda lidam com as mesmas questões (contraste, definição, tons, etc.), e devem se precaver no momento da tomada se quiserem obter o máximo de aproveitamento da tecnologia; contudo é evidente também que estes aplicativos estão nos microcomputadores daqueles que não são necessariamente profissionais, e as mesmas telas permitem a visualização da imagem em ambos os casos de atuação. É claro que um fotógrafo profissional com conhecimento mais apurado acaba por explorar de maneira mais eficiente esses softwares, mas o envolvimento espontâneo de um usuário não profissional não é mais tão arriscado como seria nos processos fotoquímicos. 0 "sistema de zonas" de Adams ainda existe, mas "imerso nas caixas pretas" está num mesmo nível de interfaceamento para todo tipo de usuário.

\footnotetext{
12 "(...) the function of the Zone System is to establish a working technique that enables the photographer better to manage creative visualizations. I do not think the Zone System is fully valid in creative photography without visualization of the expressive imagem before the exposure is made". In: ADAMS, Ansel. An autobiography. New York: Little Brown and Company, 198, p. 325.
} 
0 discurso tecnológico era efetivamente visível e manipulável: o cheiro do ácido, as mãos molhadas, o peso do papel, a pinça, a banheira, as condições de luminosidade anormais, etc. Existia, portanto, um interfaceamento tecnológico bastante expressivo no caso da fotografia convencional: se tal como Flusser afirma, as imagens técnicas são biombos, esses procedimentos reforçavam sua estrutura; se as imagens são mapas, esse interfaceamento era 00 invólucro do mapa. Hoje, com essa economia de matéria, o usuário está com o "mapa nas mãos": a tela.

Cabe relembrar o que foi afirmado no capítulo 2: a tecnologia do suporte é determinante da tecnologia da máquina. A tela talvez seja o que mais se aproxima de um "suporte" para a imagem digital, pois ali é possível a visualização num nível de interfaceamento primário (números que se convertem em informação luminosa). A pequena tela é onipresente na prática da fotografia contemporânea: nem todas as câmeras trazem a possibilidade de "pré-visualização" (real live), mas todas permitem a visualização imediata após a tomada. Ainda que, para os profissionais, as câmeras fotográficas digitais ainda sejam construídas tendo-se a mesma estrutura daquelas disponiveis para películas (o que permite manter muito de seu parque tecnológico para 0 intercambiamento de objetivas ou para o uso de acessórios), a tela é componente obrigatório. A esfera mítica ao redor da Leica se mantém, e suas câmeras digitais continuam as mais onerosas; a Nikon e a Canon tornaram-se os principais fornecedores de equipamento deste porte para 0 mercado profissional (além de também suprir parte de um mercado doméstico); e hoje também há opções provenientes de fabricantes sem tradição na fotografia com película, mas com prática no mercado da imagem eletrônica ou da informática (Sony, HP, etc.): a oferta de tecnologia é gigantesca, mas a tela tornou-se a principal estrutura presente num sistema fotográfico contemporâneo.

Fotografias se movem de tela em tela: do painel LCD da câmera para a tela do microcomputador, deste para a televisão, ou para um aparelho de telefonia celular. A tela passa a ser presença constante na práxis da fotografia. Vive-se, hoje, pela observação dessas superfícies e nelas se concentra grande parte do fazer fotográfico contemporâneo. Cabe explorar que tipo de vivência é essa, como se pretende no próximo capítulo. 
Observados alguns aspectos do universo digital, cabe agora dar andamento às reflexões suscitadas pelo mapeamento da fotografia, que aqui foi proposto a partir do pensamento de Flusser em Filosofia da caixa preta. ${ }^{1}$ Tal obra é, na verdade, o primeiro de dois textos do filósofo que formarão o eixo de análise desta tese. 0 segundo texto, 0 universo das imagens técnicas: 0 elogio da superficialidade, ${ }^{2}$ que, assim como revela o próprio filósofo, é o aprimoramento de suas reflexões desenvolvidas na caixa preta, traz uma perspectiva de análise que parece já levar em conta muitos aspectos que nortearam os temas apresentados no capítulo anterior, a saber, 0 numérico, a manipulação de zeros e uns, e principalmente, a tela.

Já no prefácio do elogio ${ }^{3}$, Norval Baitello Jr. aponta que a caixa preta teria obtido uma leitura simplista e, sendo confundida com uma reflexão sobre a fotografia, não se teria percebido a tomada da técnica fotográfica como modelo de aparelho pós-industrial. De fato, a profundidade

\footnotetext{
${ }^{1}$ FLUSSER, Filosofia da caixa preta, op. cit.

${ }^{2}$ Idem, $O$ universo da imagens técnicas, op. cit.

${ }^{3}$ Idem, p. 10.
} 
do elogio torna mais clara a abrangência dos conceitos cunhados através da fotografia na caixa preta, no entanto, tal profundidade não deixa também de ser uma possibilidade para compreender a importância do papel da fotografia no pensamento do filósofo. É neste ponto que aqui se pretende insistir.

Oportuno lembrar que na caixa preta têm-se ordenados os capítulos "A imagem", "A imagem técnica", "0 aparelho", "0 gesto de fotografar","A fotografia”,"A distribuição da fotografia”,"A recepção da fotografia","0 universo fotográfico","A necessidade de uma filosofia da fotografia" e o "Glossário para uma futura filosofia da fotografia". Já no elogio, tem-se uma estrutura que busca envolver nitidamente os modos de ser perante os aparelhos e na era pósindustrial, deixando de lado a tentativa de priorizar a fotografia como modelo, sendo os capítulos: "Advertência", "Abstrair", "Concretizar", "Tatear”, "Imaginar", "Apontar", "Circular”, "Dispersar”, "Programar", "Dialogar", "Brincar", "Criar”, "Preparar", "Decidir", "Dominar", "Encolher" e, por último, "Música de Câmera".

Se na caixa preta vê-se uma abordagem mais concentrada na detecção do objeto, valendo-se de uma reaproximação com a prática por meio da fenomenologia, e assim tentando modelizar a fotografia como tecnoimagem ${ }^{4}$ fruto do aparelho, no elogio percebe-se que o foco de interesse está direcionado ao clima existencial que as tecnoimagens e os aparelhos parecem promover. No primeiro, um posicionamento mais objetivo da fotografia dentro da história humana de construção de símbolos (como produto pós-industrial), e no segundo, o que essa simbologia permite vivenciar.

Mas seria possível enxergar a transição entre as duas obras como a própria evidência da transição da fotografia praticada tradicionalmente e agora praticada na era digital?

A primeiro teria sido lançada em 1983 e a segunda, em 1985': tal constatação revela que o contexto imagético da fotografia não teria sofrido ainda o impacto do universo digital, como se vivencia na contemporaneidade. 0 aplicativo Adobe Photoshop, por exemplo, foi criado em 1989 e disponibilizado no mercado em 19946; assim como a primeira câmera digital a ser

\footnotetext{
${ }^{4}$ No elogio, o autor usa tanto tecnoimagem quanto imagem técnica como designação desse tipo de imagem. Opta-se, aqui, pela mesma indiscriminação.

${ }^{5}$ Filosofia da caixa preta foi primeiramente lançado em alemão, em 1983; em português, em 1985 (Ed. Hucitec) e 2002 (Ed. Relume Dumará), sendo esta última, a versão aqui utilizada. Já 0 universo das imagens técnicas, lançado em 1985 em alemão, foi recentemente lançado no Brasil com o subtítulo elogio da superficialidade, de acordo com o titulo indicado nos originais em português datilografados pelo próprio Flusser, conforme revela Norval Baitello Jr. no prefácio da obra.

${ }^{6}$ Informaç̧ões colhidas no web site da companhia: http://www.adobe.com. Acesso em novembro de 2009.
} 
comercializada, a Kodak DCS, surgiria em $1991^{7}$. Flusser não conviveu com tais inovações tecnológicas, e isto parece minar a tentativa de estabelecer o paralelo proposto acima. Mas no elogio, logo ao início, o filósofo já estende sua análise às consequências da fotografia, quando aponta também a televisão como modalidade de tecnoimagem, o que mostra a influência do vídeo para a construção de suas reflexões. Para ele, portanto, imagem fotoquímica e imagem eletrônica ocupam o mesmo nível ontológico, mas o que se pretende demonstrar aqui é que este "universo das imagens técnicas", essa "superficialidade" a ser elogiada, apesar de já terem sido notados com a presença da fotografia química e do vídeo, ganham mais evidência na tecnologia numérica.

Primeiramente, vale retomar o caráter pós-industrial que Flusser atribui à fotografia desde a sua criação: nessa dimensão, nas palavras do filósofo, tem-se a sobreposição da informação sobre o objeto. Retomando-se a constatação de que a tecnologia da fotografia teria caminhado para uma "desmaterialização" do suporte da imagem e para uma portabilidade de seu aparato, como se buscou aqui evidenciar nos primeiros capítulos, ver-se-á que tal caráter pósindustrial ganha contornos mais expressivos no universo digital. Como dito, do metal (daguerreótipo) passou-se ao vidro (colódio), do vidro para o celuloide (filme), do celuloide para cargas elétricas discretas (digital). 0 metal, o vidro, o celuloide tinham, cada um, sua materialidade, seu peso, suas texturas: eram, sim, informação, mas também eram objetos. No digital, a matéria deixa de existir. Flusser, no elogio, denomina essa condição existencial no "vácuo dos quanta"8 como a zero-dimensão.

Tal condição seria a quarta fase na história da relação entre homem e natureza, fase esta inaugurada pela fotografia. Nota-se, no elogio, o decorrer dessas etapas, quando "fenomenologiza" sobre a "história da cultura do homem", expondo a sua tese da "escalada da

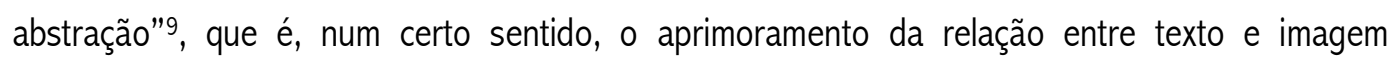
desenvolvida na obra anterior. Nas palavras do filósofo, num primeiro momento o homem conviveria com um mundo de volumes, e diferentemente de muitos animais, utilizaria suas mãos para modificar os objetos; e nessa primeira fase, a da manipulação, isto é, quando "para" os objetos e "segura os volumes", o homem se transforma em ente abstraidor, pois abstrai o tempo do mundo concreto, e este mundo se torna "circunstância". Num segundo momento, ao perceber

\footnotetext{
${ }^{7} \mathrm{Na}$ verdade, tratava-se de um circuito com CCD acoplado a uma câmera Nikon F3, e exigia um gravador acoplado externamente com 200 MB de capacidade, de porte considerável, obrigando o fotógrafo a carregar o sistema numa bolsa (Gustavson, 2009: 340).

${ }^{8}$ FLUSSER, 0 universo das imagens técnicas, op. cit., p. 15.

${ }^{9}$ Idem, pp.15-22
} 
que as mãos obedecem aos olhos, o homem passaria a agir conforme projeto, quer dizer, passaria a imaginar antes, para agir em seguida: surge, daí, a capacidade de abstrair a profundidade da circunstância, do concreto a ser manipulado. Mas ao passar a viver pelas imagens (o que ele teria chamado de idolatria na caixa preta), o homem tentaria explicá-las, tentaria torná-las "contáveis". Surge o texto: conceitos ordenados e alinhados que concebem imagens; o terceiro gesto abstraidor. "0 universo mediado pelos textos, tal universo contável, é ordenado conforme os fios dos textos", e o quarto movimento abstraidor seria perceber que "a ordem descoberta pelas ciências" (o texto aprimorado) é projeção da linearidade lógicomatemática desses textos: deve-se jogar fora essa linearidade, pois o homem perdeu a confiança nesses fios condutores. E na metáfora abaixo proposta pelo filósofo, quando compara a escrita a um cordão de pedras, vê-se com mais clareza o papel do universo digital na composição dessa quarta etapa de abstração:

As pedrinhas dos colares se põem a rolar, soltas dos fios tornados podres, e a formar amontoados caóticos de partículas, de quanta, de bits, de pontos zero-dimensionais. Tais pedrinhas soltas não são manipuláveis (não são acessíveis à mão) não são imagináveis (não são acessíveis aos olhos) e nem concebíveis (não são acessíveis aos dedos). Mas são cáculáveis (de calculus=pedrinha) (...) Em consequência, o cálculo e a computação são o quarto gesto abstraidor (abstrai o comprimento da linha) graças ao qual o homem transforma a si próprio em jogador que calcula e computa 0 concebido. ${ }^{10}$

Quando afirma a possibilidade de o homem tornar-se "jogador que calcula e computa", ação facilmente constatável nas práticas cotidianas que se servem de processos informatizados, Flusser dá indícios de rever um importante eixo desenvolvido na caixa preta, que foi a análise empreendida a respeito do homem como usuário dos aparelhos produtores de tecnoimagens e que, naquela obra, foram classificados como funcionários ou fotógrafos experimentais.

"Quem vê álbum de famíla, vê memória de aparelho", teria dito ao sustentar sua hipótese de que o humano obedece à sua cria tecnológica, e não o contrário. E como já apontado, para burlar essa condição de funcionário do aparelho, somente os fotógrafos experimentais é que sabem do problema a resolver, é que sabem obrigar o aparelho a produzir imagem que não esteja programada. 0 problema é que esse fotógrafo experimental aparece tarde demais na argumentação de Flusser na caixa preta, o que garante ao seu livro um tom bastante

\footnotetext{
${ }^{10}$ Idem, p. 17.
} 
pessimista quanto à possibilidade de processos criativos numa perspectiva de atuação mais livre. Parece não haver saída: o programa e o aparelho, largamente desenvolvidos ao longo do livro, dificultam vislumbrar o que seria exatamente uma atuação experimental contra esses dois pilares de seu modelo interpretativo. Dificuldade essa que se buscou ultrapassar, no capítulo 7, com a análise da atuação de Rosângela Rennó em "A última foto".

Retome-se, então, a fotografia de Rennó: afinal, o que há de experimentalismo ali? Poder-se-ia dizer que o ponto de vista tomado por ela é um experimentalismo? Não, pois tal ponto de vista é comumente tomado pelos funcionários em sobrevoos na cidade do Rio de Janeiro, ou no próprio monumento do Cristo Redentor, quando estes voltam suas câmeras para a deslumbrante paisagem vista lá de cima. Não há mais nada na imagem que seja suficiente para classificá-la como "experimental". 0 "brilho" da imagem surge quando comparada com as dos outros fotógrafos, foi afirmado, e Rennó evidencia uma experiência conscientizada, sem necessariamente exigir o domínio tecnológico.

Flusser, em seu elogio, sugere uma nova possibilidade de atuação que parece ser um amálgama de suas duas categorias de usuários apontadas na caixa preta, e que serviria para classificar a atuação de Rosângela Rennó com maior precisão. Observe-se a passagem no capítulo "Brincar":

0 problema da produção de informações novas deve se afastar deste contexto mitificador, se quisermos captar as virtualidades revolucionárias que a telemática nos oferece. 0 nosso desafio não é uma sociedade de deuses ou de artistas inspirados, mas sim uma sociedade de jogadores. ${ }^{11}$

Rennó, portanto, é muito mais um exemplo de jogadora do que de fotógrafa experimental. De fato, pode-se afirmar até que a coisa se inverte no elogio: se antes o funcionário era o foco de interesse para os questionamentos do filósofo, agora quem é questionado é 0 fotógrafo experimental, pois ser experimental é, em muitos aspectos, o mesmo que ser um artista. Com a ideia de jogador, Flusser equaliza o homem dentro de uma perspectiva mais branda e mais condizente com a cena digital. 0 método do jogador não deve ser a "inspiração", mas "o diálogo com os outros e consigo mesmo", de forma a permitir a elaboração de informações novas por meio de informações recolhidas ou já armazenadas. ${ }^{12}$

\footnotetext{
${ }^{11}$ Idem, p. 91.

${ }^{12}$ Idem, p. 93. Cabe ainda dizer que exemplo de Rennó se torna ainda mais gritante quando se leva em consideração seu histórico de atuação, que objetiva trabalhar com fotografias já existentes e retiradas da "vala comum do esquecimento".
} 
Tal condição existencial para o fotógrafo surge a partir do momento em que Flusser reconhece de forma mais otimista a inevitabilidade do programa e do aparelho. 0 aprimoramento destes termos, que Flusser desenvolve no elogio, torna-se mais evidente quando pensado sob as estruturas do universo digital. 0 filósofo afirma que o aparelho, muito mais automático agora, permite ao seu usuário permanecer na superficialidade do processo, concentrando-se em suas intenções e experiências vividas, não cabendo mais, portanto, a necessidade de se levar em conta o "interior" da caixa preta (tal tarefa ficaria sob a tutela dos técnicos e físicos). Quem busca imaginar pode desprezar levemente a "pretidão das caixas", sendo que "tudo que o imaginador precisa fazer é imaginar as imagens e obrigar o aparelho a produzi-las". Tal jogador ocupa-se com o input e o output, apenas: foi "libertado para a superficialidade" 13.

0 elogio surge quando Flusser reconhece a superficialidade como o surgimento de "nível de consciência novo", sobretudo por este permitir, segundo o filósofo, a possibilidade de concretizar experiências imaginadas. "Imaginar", na era das tecnoimagens, aponta Flusser, "significa a capacidade de concretizar o abstrato". Trata-se de significado diametralmente oposto das imagens tradicionais: se antes ao homem cabia abstrair a profundidade, agora cabe juntar partículas, pontos ou grãos. Levando em conta essa posição ontológica das tecnoimagens, Flusser dirá que "as gerações anteriores não podiam sequer imaginar o que o termo imaginar significa", vale dizer, a possibilidade de concretizar o imaginário só é possível para aqueles que vivenciaram a existência de aparelhos. ${ }^{14} 0$ filósofo afirma:

Pois é isto o novo nessa consciência, nessa imaginação emergente: que os discursos da ciência e da técnica, embora, assumidamente indispensáveis, são doravante tidos como banalidades, e que a aventura é buscada alhures. ${ }^{15}$

"Queremos e fazemos o que as imagens querem e fazem, e as imagens querem e fazem o que nós queremos e fazemos": o programa passa a indicar um circuito fechado entre homem e imagem. E o agente externo que alimentaria tal circuito seria o aparelho. 0 complexo caixa preta torna-se um agente com perspectivas mais otimistas: a "cobiça por sensações" e novas imagens são sintomas de tédio num mundo em que tudo tende a ser fotografado, filmado e videoteipado,

\footnotetext{
${ }^{13}$ Idem, p. 43.

${ }^{14}$ Idem, p. 41.

${ }^{15}$ Idem, p. 42.
} 
diz Flusser, e a conscientização dessa "condição espectral" de existência é que garantirá o divertimento do jogador. ${ }^{16}$

Flusser, no elogio, dá margem para perceber tanto a banalização da tecnologia, isto é, "o desprezo pela pretidão das caixas", quanto a desespetacularização da tecnoimagem, quando assume novo estado de consciência dentro desta quarta etapa de sua escalada da abstração. 0 mundo traduzido em cenas, todas fotografáveis, torna-se inevitável, mas não por isto, impossível de vivência. 0 elogio da superficialidade é o elogio da caixa preta.

Do mergulho no espaço-tempo do mundo à manipulação (tridimensionalidade), desta para a imaginação (bidimensionalidade), seguida da concepção (unimensionalidade), e por fim, uma nova forma de imaginação (a zero dimensão). Abstração é o mesmo que distanciamento. Quando se abstrai, é inevitável o afastamento. 0 propósito de toda abstração", diz Flusser, "é o de tomar distância do concreto para poder agarrá-lo melhor"17. Tal nova forma de imaginação, que pode ser vivenciada pelas tecno-imagens, seja pelo ponto, seja pelo cálculo, representa possibilidade de percepção do concreto numa outra ordem.

Enfim, vale sintetizar por que aqui se considera que o digital se ajusta melhor ao quarto movimento abstraidor, isto é, à era das tecnoimagens.

Em primeiro lugar, por ser nulodimensional na sua estruturação, pois o zero e um nada mais são do que representações de carga elétrica discreta; não são objetos, não possuem forma como nos pontos de sais de prata, mas apenas intensidades. E por serem informação de referência apenas (amostragens), por serem representações mais fragmentadas do que as informações do sinal analógico contínuo do vídeo, situam-se melhor como "pedrinhas soltas que se põem a rolar", para ficar nas palavras de Flusser.

Em segundo lugar, a possibilidade do cálculo como gesto abstraidor torna-se mais evidente no universo da microinformática, por meio dos aplicativos e teclas que garantem ao homem tornar-se, como nas palavras de Flusser, "jogador que calcula e computa". Quando afirma que "ao apertar as teclas da minha máquina, toda a minha existência se concentra sobre as pontas de meus dedos"18, e que estamos no mundo por intermédio de teclas, Flusser vislumbra circunstâncias que agora, na contemporaneidade, se fazem muito mais evidentes.

\footnotetext{
${ }^{16}$ Idem, pp. 61-63.

${ }^{17}$ Idem, p.18.

${ }^{18}$ Idem, p. 35.
} 
Enfim, em terceiro e último lugar, tem-se um equivalente "concreto" para a sua superficialidade: as telas. Ainda que estas operem na bidimensionalidade, não se pode classificálas da mesma forma que as telas das imagens tradicionais: nas telas contemporâneas os elementos pontuais se juntam, trazendo as "imagens imaginadas", "imaginação de segundo grau", "uma forma de imaginação inimaginável antes da invenção de aparelhos e teclas". ${ }^{19}$

0 próximo capítulo se ocupará com a observação mais atenta da tela; esta que, segundo Flusser, consiste na "estrutura terminal" do universo das tecnoimagens, ou ainda nas palavras do filósofo, as superfícies onde se condensam os pontos e cálculos sobre o abismo da zerodimensão.

${ }^{19}$ Idem, p. 38. 
Ao falar de telas surgem superfícies, e como se viu em Flusser, trata-se de uma possibilidade concreta de vivência, "um nível de consciência novo". As telas são onipresentes e cada vez mais é possível notar as evoluções tecnológicas concentrando seus esforços em reduzir os aparelhos às suas superfícies apenas ${ }^{1}$. A tela tem se tornado cada vez mais a principal interface entre o homem e o aparelho. Hoje, muito se pode fazer por meio do toque na tela, sendo até não mais necessário, nesses casos, apertar botões ou teclas da mesma forma que anteriormente: 0 destino de todo aparelho parece ser a tela.

Como já dito, a fotografia circula de telas em telas. Surgem, num primeiro momento, no painel luminoso presente nas câmeras fotográficas contemporâneas. Muitos fabricantes, por exemplo, preocupam-se em garantir telas cada vez maiores, vendo nesse componente um forte elemento sedutor para o consumo, às vezes até mais do que o número de pixels que a câmera

\footnotetext{
${ }^{1}$ Encontram-se exemplos dessa tendência nos dispositivos construídos pela Apple, empresa norte-americana que tem forte influência nos usuários e profissionais da imagem, tanto na fotografia, quanto no cinema e vídeo. Os desktops mais recentes, os iMac's trazem telas de até 27", com todo o hardware necessário para o funcionamento do sistema embutido na tela. Somente teclado e mouse como periféricos, sendo o primeiro de tamanho bastante reduzido, e ambos sem a necessidade de cabos de conexão. Outro dispositivo desta empresa, o aparelho celular iPhone, representou expressiva evolução no mercado tecnocrático, quando priorizou o sistema de touch screen (toque na tela) ao invés de teclas.
} 
oferece. Os mecanismos das câmeras de alguns modelos chegam a ser meros acessórios da tela, dada a dimensão desta nesses aparelhos.

Essa estruturação da câmera em função da tela reforça a ideia de que a tecnologia da fotografia está atingindo o seu momento máximo de simplificação dos procedimentos laboriosos para a obtenção da imagem, uma vez que se pode dizer que não mais se apontam câmeras para o mundo, apontam-se telas.

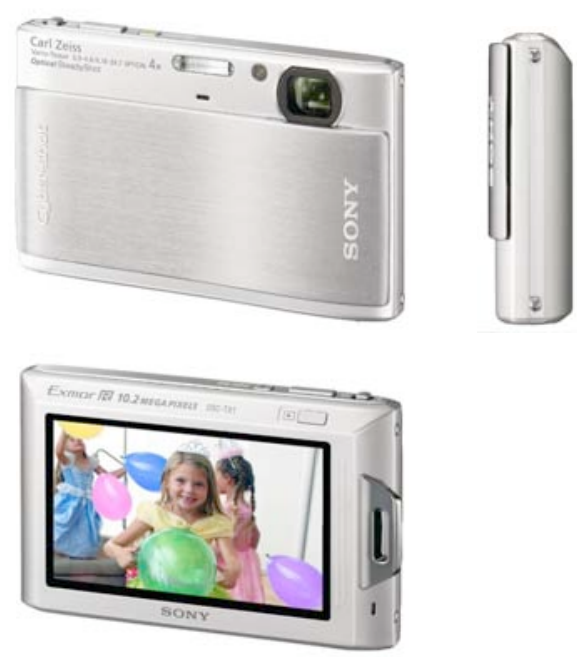

Fig. 28: Três vistas da Câmera sony modelo Cybershot DSC TX1 com "tela" de 3 polegadas, e com 1,5 cm de profundidade.

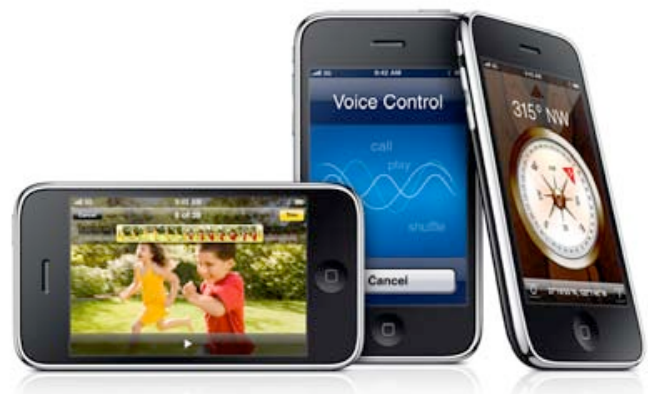

Fig. 29: 0 iPhone, aparelho celular com sistema fotográfico digital embutido.

Mas quais seriam as perspectivas de uso que decorrem desta forma de fotografar por meio de telas, e não mais por meio de câmeras?

Existe uma dificuldade incontornável para responder a esta questão. Uma vez que essa constatação do "todo" reduzido à tela permite afirmar a hibridização das mídias contemporâneas, como localizar o específico da fotografia em meio à cena audiovisual dos dias atuais? Somente serão encontrados subsídios para abordar as especificidades de cada meio ao deparar-se com 0 momento em que esta imagem é gerada. É daí que surge a dificuldade: a tela, sempre uma instância final de um processo criativo audiovisual, tende a encerrar a fotografia no mesmo momento da tomada.

Ainda que se possa vislumbrar o tratamento digital, a manipulação permitida pelos softwares cada vez mais acessíveis, isto é, a ideia da fotografia em sistema (cf. capítulo 8), também é icontornável a constatação de que o grosso das imagens produzidas estão 
armazenadas nos microcomputadores e quase sempre não são mais acessadas após a tomada. Tal como Jorge Coli aqui já apontou, "facilidade rima com banalidade" ${ }^{2}$, e isto fica claro ao se perceber a avalanche de fotografias continuamente produzidas, consumidas, descartadas ou esquecidas. A tela possui papel fundamental nesse processo de aparente redefinição do valor de uma imagem fotográfica: sendo possível ver a imagem antes de fotografar (pelo preview do painel $)^{3}$, assim como a imagem pode ser vista imediatamente após a tomada, mundo concreto e imagem se mesclam, e isto diminui drasticamente o espaço para justificar a necessidade da imagem.

Levando-se em conta as relações genealógicas entre fotografia, cinema e vídeo, pode-se constatar que a fotografia é a base de todos eles, como apontado no início desta tese. Da fotografia surge o cinema, e do cinema (imagem em movimento) surge o vídeo; do vídeo surge a tecnologia que será a base de toda fotografia digital (CCD). Ao mesmo tempo, presencia-se uma dinâmica de signos em que uma imagem estática que é gerada por um aparelho de telefonia celular pode ser transmitida para a exibição numa tela de um microcomputador, o qual, por sua vez, também pode exibir um filme produzido pela mais alta tecnologia cinematográfica, ao mesmo tempo que este mesmo filme pode ser "pirateado" por uma câmera fotográfica digital que seja capaz de gravar em vídeo. Estas trocas se dão com tamanha densidade atualmente que, ao mesmo tempo em que garantem uma explosão de possibilidades, trazem, em termos tecnológicos, uma generalização imagética à cena audiovisual. Ou seja, tudo indica que não haverá mais sentido em se diferenciar estruturalmente imagem fotográfica, imagem do vídeo e imagem cinematográfica: todas parecem convergir à tela.

Por outro lado, se a fotografia convencional foi um início, por que não arriscar a afirmação de que a fotografia digital possa ser também classificada como um novo ponto de partida? Seria forçoso, ao menos sugerir, que a mudança de paradigma tecnológico da fotografia leva à ideia de um novo começo para o audiovisual como um todo?

Viu-se anteriormente o peso da tecnologia na definição não só do que era a fotografia (filosofia da caixa preta), mas também, e principalmente, do que pode ser a relação com a tecnoimagem (elogio da superficialidade). Agora com a tela, a fotografia digital permite

\footnotetext{
${ }^{2}$ COLI, Jorge. Rascunhos e harmonias. São Paulo: Folha de S. Paulo, Caderno Mais, p. 2, 6 de agosto de 2006.

${ }^{3} \mathrm{Nem}$ todas as câmeras possuem tal preview, mas é uma tendência que pode ser observada pela recente introdução do mecanismo em câmeras digitais profissionais ou semiprofissionais, que até então não apresentavam tal possibilidade por serem destinadas a fotógrafos dotados de domínio técnico maior.
} 
instrumentalizar a tecnoimagem de uma maneira que não mais se confunde com a instrumentalização de seu maquinário. A tecnologia fotográfica definitivamente deixa de ser instrumento, e o aparelho de Flusser tende a se resumir à superficialidade da tela na era digital.

$\mathrm{Na}$ passagem abaixo, de Rubens Fernandes Jr., tem-se uma síntese que pode servir como motivação para explorar o tema:

\begin{abstract}
Um rápido e breve olhar retrospectivo nos mostra que o daguerreótipo (1839), primeira manifestação tecnológica visual, era produzido por um artista e recebido por um leitor de cada vez. 0 kinetoscópio do inventor norte-americano Thomaz Edson (1887), também era concebido por um criador, que disponibilizava sua produção na máquina, que acionada por uma moeda, permitia que apenas uma pessoa pudesse assistir os filmes. Novamente um produtor e um leitor. Com o avanço tecnológico, buscava-se ampliar a escala de recepção. (...) Aos poucos, o receptor único e passivo transforma-se num produtor de imagens; e nos últimos anos, é parte integrante da cadeia criativa, já que é possível fotografar e compartilhar a experiência em diferentes momentos. ${ }^{4}$
\end{abstract}

Tal consideração revela que essa instrumentalização da imagem se mostra com mais evidência quando se percebe a escala de recepção na contemporaneidade que é promovida nas telas. É certo que os jornais e revistas ao longo do século XX muito colaboraram para a proliferação da fotografia, mas restritamente definida dentro de um âmbito profissional de criação fotográfica (jornalística, sobretudo). 0 que se vê hoje, com o Flickr, o Youtube e os blogues, por exemplo, é o redimensionamento da divulgação das imagens daqueles que não são necessariamente profissionais.

Nas telas dos microcomputadores contemporâneos, as imagens fotográficas familiares disputam o mesmo espaço, vale dizer, a mesma tela de veiculação das fotografias jornalísticas. Isto deve ser considerado como evidência de uma alteração considerável no contexto. Nada mais evidente do que tomar de empréstimo o termo "página da internet": as fotos de conflitos e guerras, e de todos os outros gêneros, nas páginas eletrônicas de jornais e afins, misturam-se às fotografias de viagem, festas e momentos memoráveis de muitos, que podem ser vistos nas páginas dos mútiplos blogues, mas também num simples slide show que traz imagens recémproduzidas; tem-se agora um grande álbum de família ou um grande jornal, não importa, pois se mesclam enquanto são "folheados".

\footnotetext{
${ }^{4}$ Parte da conferência de abertura na entrevista realizada com os coletivos fotográficos Cia da Foto e Pandora, no Paraty em Foco, em 27/9/2009. Disponível em: http://www.ciadafoto.com.br/blogue.
} 
A tela abarca o universo pragmático-fotográfico em sua totalidade, abrangendo desde 0 profissional mais tecnicamente capacitado até o menos preparado fotógrafo de família: "arremata a fotografia no atacado" ${ }^{5}$. As experiências vividas caem na tela sob uma perspectiva de equalização criativa, muito adequada à idéia do jogador, de Flusser. Pois tornou-se impossível definir o que pode ser "novo" em termos imagéticos, no sentido mais original do termo, que no caso da práxis fotográfica, poderia ser aquela fotografia inédita, nunca realizada.

$\mathrm{Na}$ acepção de Régis Debray, "ao longo do século XX, dessacralização da imagem e sacralização do fabricante andaram par a par". É o que afirma como um processo "do fazer para o ser"6. Este processo encontra no digital um importante dispositivo para sua continuidade? Pode-se afirmar, baseando-se em Flusser, que essa sacralização do fabricante (o artista, no caso) que Debray aponta, não irá encontrar espaço num universo de redes dialógicas destinadas aos jogadores.

Essa subjetividade que Debray busca evidenciar foi, sim, e ainda até pode ser atuante na esfera da arte, onde ainda se vive sob o mito de "artistas inspirados"; porém, não se pode negar que tal inspiração deve ser questionada pelo esgotamento de possibilidades que as telas não cessam de reforçar: assumir que se cria algo originariamente novo torna-se bastante arriscado para aqueles que acreditam em sua própria "divindade". 0 novo não se justifica mais pela plasticidade da imagem, mas pela intensidade: tornou-se também um problema de se saber onde e quando colocar as peças no tabuleiro, vale dizer, a imagem na tela.

Vejam-se dois exemplos de atuação para balizar a discussão. Retome-se, de início, Ansel Adams, que anteriormente foi usado como exemplo de "divindade" da tecnologia da fotografia no século XX, mas que hoje também é referência no círculo das artes. 0 fotógrafo produziu imagens exuberantes de parques naturais norte-americanos, publicou tratados sobre a tecnologia da fotografia, desenvolveu toda uma sistemática de trabalho com os grãos de prata para a exploração de tons na fotografia em preto e branco, o "sistema de zonas", consagrando-se, enfim, como um dos maiores e mais influentes fotógrafos do século XX. Já o fotógrafo (também norte-americano) Noah Kalina realizou, a partir de $1^{\circ}$ de janeiro de 2000, um autoretrato a cada dia ao longo de seis anos e meio. Com as 2.356 imagens resultantes elaborou um audiovisual

\footnotetext{
5 "Com o hibridismo que dilui as fronteiras entre as formas tradicionais da arte e a difusão dos sistemas digitais que retiram da imagem a diferença de seu suporte, algo do que é propriamente fotográfico aparenta evanescer-se. Agora, portanto, ao modo de Benjamin, pode ter chegado o momento de arrematar a fotografia no atacado." In: LISSOVSKY, op. cit.

${ }^{6}$ DEBRAY, Régis. Op. cit., p. 63.
} 
com pouco mais de cinco minutos de duração, sendo que este vídeo, até recentemente, já teria cerca de 13.000.000 de acessos no youtube ${ }^{7}$.

Adams personifica a postura da "era analógica", e Kalina, a "era digital". Em Adams, representante do movimento straight photography, vê-se o discurso tecnológico e a objetividade fotográfica: imagens desconcertantes e belas que surgem por meio de uma fotografia "sagrada". Kalina se insere nas novas possibilidades da situação tecnológica contemporânea, mas com propósitos aparentemente muito mais distantes de um mundo a ser objetivado, até porque a câmera é apontada para ele mesmo (na verdade, os autoretratos foram produzidos pela câmera de seu microcomputador, ou seja, Kalina se fotografou com uma tela). Retornando a Debray, quando fala da "sacralização do fabricante", poder-se-ia dizer que Kalina representa o ápice da afirmação do "eu"; mas, pela perspectiva de Flusser sobre aparelhos e brinquedos, Kalina surge como expressivo jogador, pois suas tecnoimagens não buscam trazer infomações originalmente novas, buscam o "novo" por meio da saturação de informações (aqui caberia também o exemplo dos "googlegrams" de Fontcuberta, apontados no capítulo 4).

Mas seria correto comparar a investida fotográfica de Adams com a de Kalina? Como se pode construir paralelos entre fotos de parques naturais (realizadas com câmeras de grande formato, processadas quimicamente sob os mais rigorosos controles de contraste) com autosretratos, realizados em qualquer lugar, com baixa definição, onde o que se ve é apenas uma expressão entediada que se repete à exaustão?

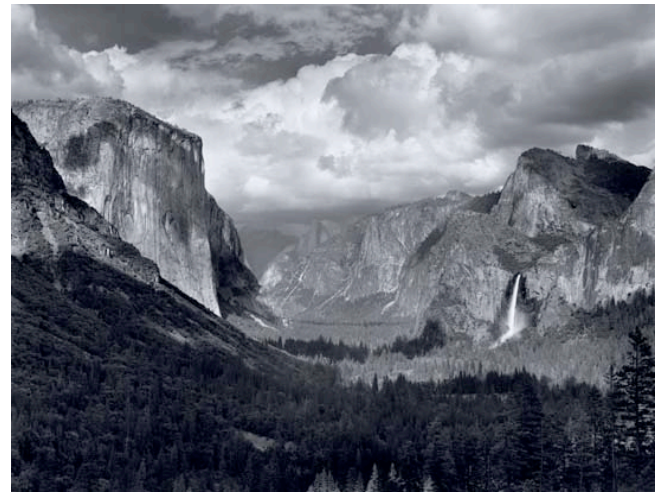

Fig. 30: fotografia de Ansel Adams.

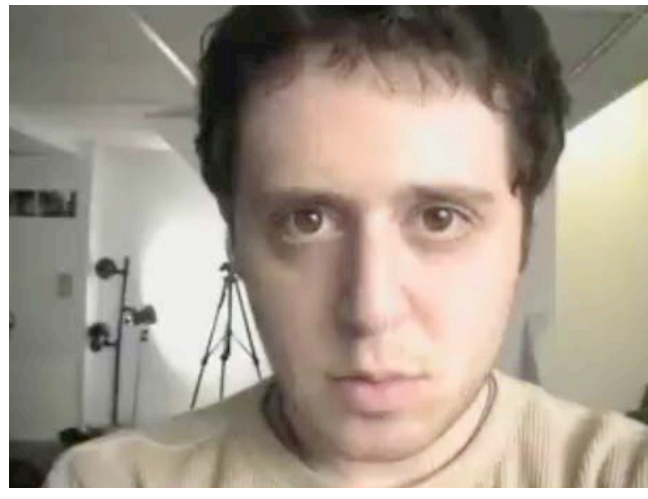

Fig. 31: fotografia de Noah Kalina

\footnotetext{
${ }^{7}$ Trata-se de "Noah takes a photo of himself everyday for 6 years". Vale citar a análise de Fenando de Tacca: "o mais assustador é que tudo muda no fluxo rápido de imagens: o cabelo, a roupa, o ambiente, a luz, mas sua face depressiva não muda e ele se mantém assim, sem sentimentos, imutável em piano suave de fundo, como uma inutilidade, e ficamos em estado de transe na obsessão desse autor, sem alternativas, impotentes perante o uso intenso dessa natureza do fotográfico". (TACCA, 2007).
} 
Pela perspectiva flusseriana de tecnoimagens, pode-se afirmar que todas as fotografias são iguais, pois representam os mesmos conceitos antes ainda de serem diferenciadas pelo motivo registrado. Ao mesmo tempo, tal constatação abre espaço para se definir a dificuldade existente de rotular a fotografia em gêneros. Levando-se em conta tais pressupostos, pode-se aproximá-las em diversos níveis (do aparelho, do funcionário, do programa, etc.). Sob tal perspectiva, a aproximação não pode ser considerada "forçosa", uma vez que se lida com a fotografia, antes de lidar com fotografias. Tal exercício de comparação é notar essa dimensão mais abrangente da fotografia e ultrapassar os invólucros dos gêneros, e isto permitirá adequar a prática fotográfica ao fluxo incessante de imagens nas telas contemporâneas.

Vídeos como os de Kalina, produzidos a partir de fotografias estáticas ${ }^{8}$, têm se tornado frequente na tela. Revelam, dessa forma, o redimensionamento da fotografia por meio de caminhos com uma dinâmica impensável para a prática que se desenvolvia na época de Adams. Aqui cabe citar novamente uma passagem de Flusser: "As gerações anteriores não podiam sequer imaginar o que o termo imaginar significa", e mesmo que esta afirmação tenha sido inspirada por um contexto com fotografias fotoquímicas e o vídeo analógico, a circulação de dados digitais a torna mais contundente ainda.

0 que se deve perguntar não é até onde vai a possibilidade da fotografia como brincadeira - nesta direção o jogo tende a ser infinito, inesgotável -; a questão deve ser formulada tendo em vista a outra direção: até que ponto a fotografia poderá ainda ser séria e reponsável, isto é, documental. Haverá espaço para isso da forma como houve ou como ainda há hoje?

Philippe Dubois teria formulado uma questão ${ }^{9}$ recentemente que aponta para 0 tema: "quando olhamos uma fotografia, vemos uma imagem (que dessa forma, será sempre uma ficção) ou vemos uma fotografia (o documento, o registro do real)"? As telas contemporâneas talvez sejam a possibilidade para se atingir o meio-termo desses extremos, se encaradas como superfícies que representam uma experiência concreta a partir das imagens.

As imagens da série Babel Tales, de Peter Funch, fotógrafo dinamarquês, dão sustentação para incrementar a discussão: todos os elementos da imagem ocorreram no mundo concreto de

\footnotetext{
${ }^{8}$ As especificidades plástico-temporais desse tipo de construção foram exploradas na dissertação de mestrado deste autor, "Fotos em cena, cenas em foto: a presença da fotografia estática na tela audiovisual." ECA/USP, 2004.

${ }^{9}$ DUBOIS, Philippe. As tensões na fotografia: entre a ficção e o real. Conferência realizada no Departamento de Jornalismo da ECA/USP. São Paulo, 1/9/09.
} 
fato, pois todos os elementos têm a sua origem na fotografia e no mesmo ponto de vista; porém, reorquestrados como estão nas imagens finais, como se pode classificá-las? São circunstâncias concretas? As imagens de Funch exercitam um deslocamento cada vez mais necessário ao habitus perceptivo diante das telas: enxergar um fotografia, uma tecnoimagem como ficção, antes de considerá-la documento.

Mesmo que esse deslocamento seja extremamente sutil ainda, as possibilidades que daí decorrem não são. Olhar uma tecnoimagem como uma ficção, antes de considerá-la documento, representa uma tremenda reviravolta no habitus perceptivo: representa definir o estatuto dessas imagens na esfera da "remagicização" de nossos conceitos sobre o mundo. 0 que significa, para ficar nos termos desenvolvidos aqui, notar o caráter ficcional de qualquer documento e 0 caráter documental de qualquer ficção.
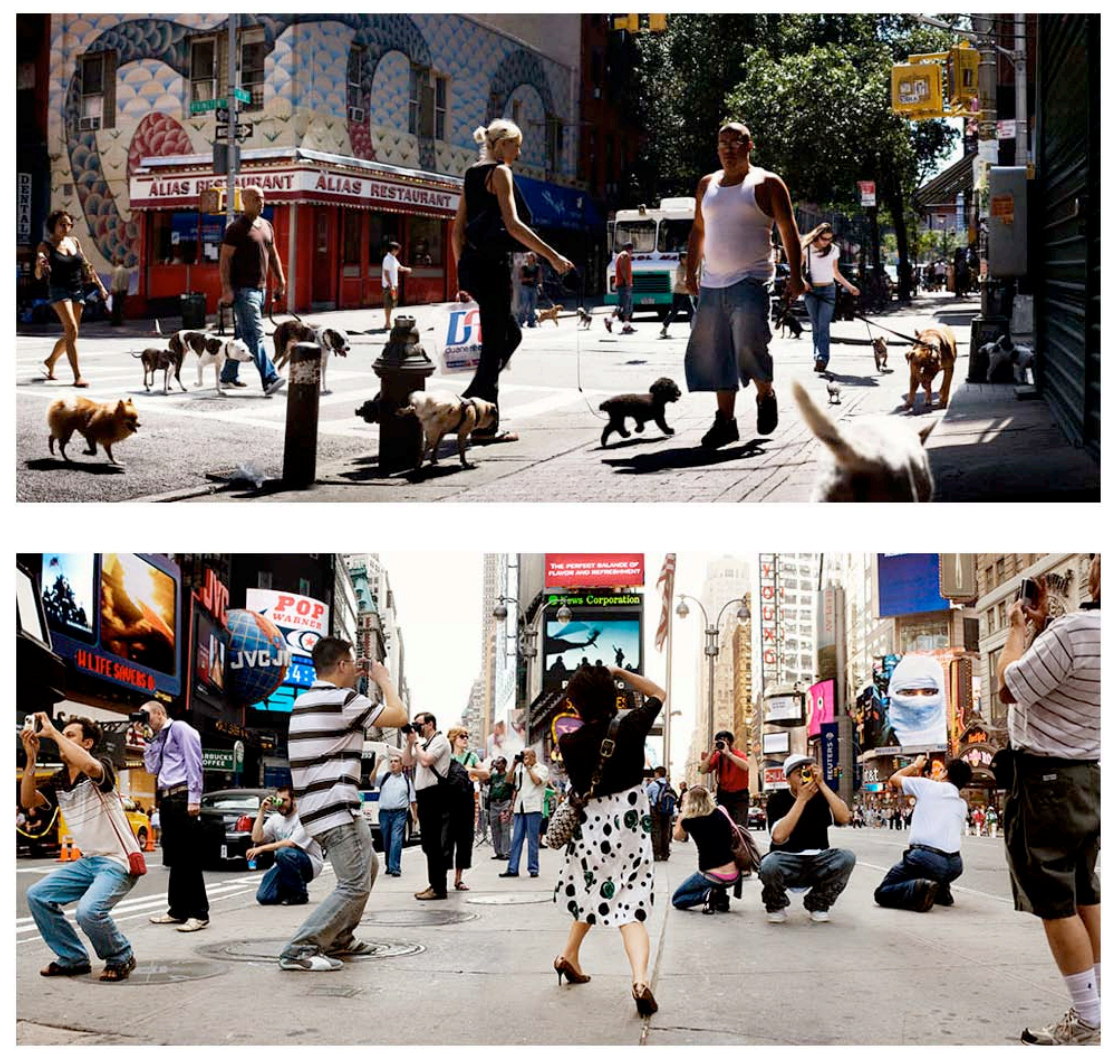

Fig. 32: fotografias de Peter Funch, da série Babel Tales.

Enfim, tendo em vista tamanha enloquência aqui atribuída às telas, cabe ainda uma pequena digressão, até como forma de justificar o título deste capítulo. Desenhados esses aspectos a respeito das telas, vale lembrar dos oceanos. Não tanto pela imensidão de sua superfície, que 
poderia facilmente ser comparada à onipresença das telas, mas pelo valor de sua superfície. É ali que as trocas gasosas fundamentais para a sobrevivencia do planeta se dão pelos plânctons. Uma fina superfície que separa a profundidade, o abismo, a escuridão (a partir de uma certa profundidade) da magnitude do céu, do universo e do infinito. Telas se aproximam dessa condição, pois são superfícies para trocas, não tão necessárias para a sobrevivência como se dão as trocas gasosas nos oceanos, mas cada vez mais presentes e fundamentais para manutenção do imaginário. De forma que, tal como se faz de maneira bastante prazerosa no caso dos oceanos, pode-se também chegar à margem, sentar e apenas olhar as telas. 0 mergulho nas águas é decisão meramente acessória: observar o mar, a superfície do oceano, já justificaria a experiência. Tal parece ser o clima das telas em que a fotografia poderá ser experimentada em sua plenitude. 
As telas trazem as tecnoimagens, e estas são a concreção de abstrações: por elas, segundo Flusser, pode-se viver concretamente na superficialidade. Seria esta uma afirmação que busca dar novo estatuto ao que se entende por real? Enfim, quais seriam as implicações ao assumir a presença das tecno-imagens com tamanha intensidade, tal como insiste Flusser?

Para filósofos como Debord ou Baudrillard, que se ocuparam com reflexões sobre a onipresença das imagens, tal forma de vivência corresponderia à total alienação do homem. No que Flusser e a superficialidade diferem das teorias desses filósofos? É preciso examinar, ainda que brevemente, as relações entre o espetáculo, o hiper-real e a superficialidade, isto é, entre Debord, Baudrillard e Flusser, pois o que aparentemente os difere não é o objeto, mas a perspectiva de interpretação.

Baudrillard apresentou a ideia do hiper-real como reflexo de uma "precessão dos simulacros", e não há como não considerar que tal conceito se deveu à percepção da onipresença das telas e das tecnoimagens, que, para ele, comporiam uma realidade desprovida

\footnotetext{
${ }^{1}$ BAUDRILLARD, J. Simulacros e simulações. Lisboa: Relógio D'água, 1991.
} 
da necessidade de conexão com um mundo concreto, a "liquidação de todos os referenciais". Mas para respaldar seu conceito de hiper-realidade, Baudrillard se baseou numa hierarquização da verdade presente nas duas realidades comparadas, afirmando esta como potencialmente ilusória, uma vez que a simulação confunde o verdadeiro com o falso, ou nas suas próprias palavras, o "real" com o "imaginário". Para o autor, viver no hiper-real, portanto, significaria viver no plano imaginário, abolir uma possibilidade real e verdadeira de existência. Mas existe uma contradição dentro do radicalismo de seu pensamento: ora, se é verdade que o hiper-real atinge um nível presencial e atuante tal como apontado pelo próprio Baudrillard, o imaginário passa a adquirir um lugar expressivo e decisivo na vida cotidiana. Não se poderia mais definir onde está a verdade da existência contemporânea, e tanto a hiper-realidade como a realidade em que se baseia Baudrillard estariam sob um processo de deslocamento e reconfiguração. Quem diz isso é Flusser, quando afirma que "critérios históricos do tipo 'verdadeiro' ou 'falso', 'dado' e 'feito', 'autêntico' e 'artificial', 'real' e 'aparente', não se aplicam mais ao nosso mundo"2. 0 que se pode apreender da observação de Flusser é que a superficialidade, como estado de consciência novo, exige abandono da busca por profundidade, movimento este responsável pela criação de tais critérios apontados pelo filósofo.

Debord só enxerga as profundezas: "o espetáculo na sociedade corresponde a uma fabricação concreta de alienação" ${ }^{3}$. E ao também decretar que "tudo que era vivido diretamente tornou-se uma representação", Debord acentua o papel alienante das imagens que percorrem 0 mundo. Trata-se, então, do espetáculo como estrutura do real, ou seja, de uma realidade que surge no espetáculo, promovendo a "conservação da inconsciência na mudança prática das condições de existência"4. Em Debord, as imagens atenuam a capacidade de conscientização da sociedade, permitindo que o indivíduo se torne cada vez menos atuante e mais passivo perante 0 mundo concreto.

Baudrillard e Debord, ao enquadrarem as imagens de forma bastante pessimista, acabaram por mitificá-las ainda mais, pois acentuaram a partilha entre real e imaginário dentro de uma mesma grande esfera que é a técnico-científica, e que define o que existe e o que não existe, isto é, o que é concreto e o que é abstrato. Não se pode considerar o mesmo em relação a Flusser, pois este, ao elogiar a superficialidade não promove a partilha entre concreto e abstrato,

\footnotetext{
${ }^{2}$ FLUSSER, $O$ universo das imagens técnicas, op. cit., p. 45.

${ }^{3}$ DEBORD, Guy. A sociedade do espetáculo. Rio de Janeiro: Contraponto, 1997, p. 24.

${ }^{4}$ Idem, p. 21.
} 
isto é, matéria e ideia, tal como a ciência; promove uma relação de dependência entre eles, uma espécie de fusão. Admite, pois, a tecnoimagem como abstração concretizada, e não como 0 concreto abstraído, estatuto este destinado às imagens tradicionais, e no qual se baseiam os filósofos do espetáculo e do hiper-real.

"Tecnoimagens não são espelhos, mas projetores: projetam sentido sobre superfícies, e tais projeções devem constituir-se em projetos vitais de seus espectadores" 5 . Quando se afirma a possibilidade concreta de vivência na superficialidade, afirma-se a parceria das tecnoimagens como componentes de tais projetos vitais. Enfim, sugere-se aqui uma interpretação para esse universo de imagens técnicas que Flusser desenha: trata-se de um novo estatuto para "isso" que se denomina ainda de realidade e que, desde a descoberta do "vácuo dos quanta", já demonstrou ser composto de zerodimensionalidade. A superficialidade se constrói tendo esse vazio como referência. É por isso que afirma que "nada adianta perguntar se as imagens técnicas são fictícias" 6 , questão esta que Baudrillard e Debord rapidamente buscaram responder.

Susan Sontag possuía opinião similar à de Debord e Baudrillard quando redigiu seu Sobre Fotografia ${ }^{7}$, isto é, para ela, tecnoimagens eram mais ficção do que realidade. Segundo Sontag, sua obra trazia a idéia de que a "capacidade de reagir a nossas experiências com frescor emocional e com pertinência ética vem sendo minada pela difusão implacável de imagens vulgares e estarrecedoras". Na obra Diante da dor dos outros, reconhece sua postura como conservadora, por ter apontado um sentido de realidade, e não a realidade que existe e resiste a "qualquer tentativa de enfraquecimento de sua autoridade". Sontag, assim, tenta escapar da autonomia que deu às imagens naquela abordagem (TV e fotografia) e das generalizações que atribuiu ao público, pois passa a reconhecer que existe uma grande parcela de espectadores, os quais convivem com as atrocidades, guerras e fome, que "não se dão ao luxo de fazer pouco caso da realidade". Para ela, inclusive, as posturas adotadas por Debord e Baudrillard eram sintomas de um "provincianismo assombroso" que tentava universalizar um ponto de vista de uma minoria que vivia na parte rica do mundo: uma "especialidade francesa" de "crer que imagens e realidades simuladas são tudo o que existe agora" ${ }^{\text {. }}$.

\footnotetext{
${ }^{5}$ FLUSSER, 0 universo das imagens técnicas, op. cit., p. 55.

${ }^{6}$ Idem, p. 24.

${ }^{7}$ SONTAG, Sobre fotografia, op. cit.

${ }^{8}$ SONTAG, Susan. Diante da dor dos outros. São Paulo: Companhia das letras, 2007, pp. 90-91.
} 
Sontag, ao buscar o amadurecimento de sua opinião, eleva sua percepção ao nível da superficialidade de Flusser. Observe-se a passagem em que realiza novo exame das fotos de atrocidades:

Não é um defeito o fato de não ficarmos atormentados, de não sofrermos o bastante quando vemos essas imagens (...) tais imagens não podem ser mais do que um convite a prestar atenção, a refletir, a aprender(...) As imagens têm sido criticadas por representarem um modo de ver o sofrimento a distância, como se existisse algum outro modo de ver. Porém, ver de perto - sem a mediação de uma imagem- ainda é apenas ver. Algumas críticas contra imagens de atrocidade não diferem da caracterização do próprio ato de olhar. Olhar não requer esforço; requer distância espacial; o olhar pode ser desligado (não temos portas nos ouvidos) (...) Nada há de errado em pôr-se à parte e pensar. Não se pode pensar e bater em alguém ao mesmo tempo. ${ }^{9}$

A superficialidade surge na equalização das formas de ver: há somente um único modo de olhar, seja uma imagem, seja o real. E tal olhar sempre exigirá distância. Quando se fala em abstração, fala-se em distanciamento. Mesmo na experiência concreta do real, esse distanciamento é fundamental para a percepção. A superficialidade é, num certo sentido, a tentativa de assumir distância adequada, como Flusser esclarece:

\footnotetext{
0 problema é o da distância entre o observador e a imagem. De distância determinada as imagens técnicas são imagens de cenas. De outra distância, são elas traços de determinados elementos pontuais (fótons, elétrons), enquanto sob visão superficial se mostram como superfícies significativas (...) as imagens técnicas exigem que deliberemos determinada distância quanto a elas, exigem superficialidade. ${ }^{10}$
}

Em síntese: Debord e Baudrillard olham as imagens de muito longe ou de muito perto; Sontag também assim olhava, mas agora se aproxima dessa visão superficial de Flusser, ao também afirmar que "olhar não requer esforço, requer distância espacial". Foi com tal distância "superficial" que a autora estabeleceu a equalização entre imagem e real, e, dentro dos mesmos termos anteriores, pode-se dizer que Sontag admite que concretizar abstrações coloca-se no mesmo patamar do concreto que se pode abstrair: tais instâncias situam-se com a mesma intensidade na elaboração dos projetos vitais.

\footnotetext{
${ }^{9}$ Idem, pp. 97-98.

${ }^{10}$ FLUSSER, 0 universo das imagens técnicas, op. cit., p. 39.
} 
Veja-se o trabalho I photograph to remember de Pedro Meyer: uma documentação fotográfica sistemática do último ano de vida de seus próprios pais. Tomando-se a distância de Baudrillard e Debord, seria possível dizer que Meyer estaria espetacularizando a dor de seus pais e a sua própria, ou escapando do real por meio de suas imagens, ou seja, optando por abstrair o concreto. Mas, ao tomar-se a distância "superficial", a relação entre concreto e abstrato se mesclam.

Uma interpretação plausível de I photograph to remember seria considerar o seu caráter questionador a respeito da crença na objetividade fotográfica. Meyer, ao fotografar o que ninguém gostaria de fotografar, a saber, o sofrimento de algum ente querido, banaliza 0 aspecto documental da fotografia o que, inclusive, reforça a sua linha de atuação em questionar tal autoridade (ver mais à frente). Fica a vontade em fotografar algo "infotografável" por acreditar na incompletude das imagens fotográficas em definir o que é real, o concreto. A fotografia aqui, como documentação familiar, é banalizada pelo exagero. Por outro lado, ao assumir que fotografa para se lembrar, admite a abstração a ser concretizada. Meyer está diante de sua própria dor, e é o autor das imagens. Aqui se enquadra naquela categoria de espectadores de Sontag que "não se dão ao luxo de fazer pouco caso da realidade". Dessa forma, não faz sentido indagar se ele vê de perto ou vê de longe: ele simplesmente vê. Meyer exercita a superficialidade.
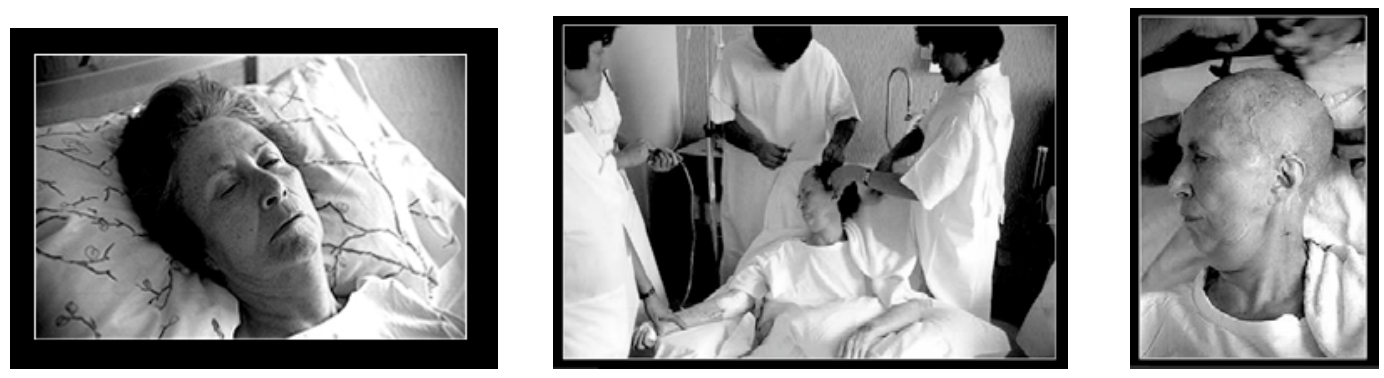

Fig. 33: mãe de Pedro Meyer sendo preparada para cirurgia. Imagens da obra "I photograph to remember". In: http//:www.zonezero.com.
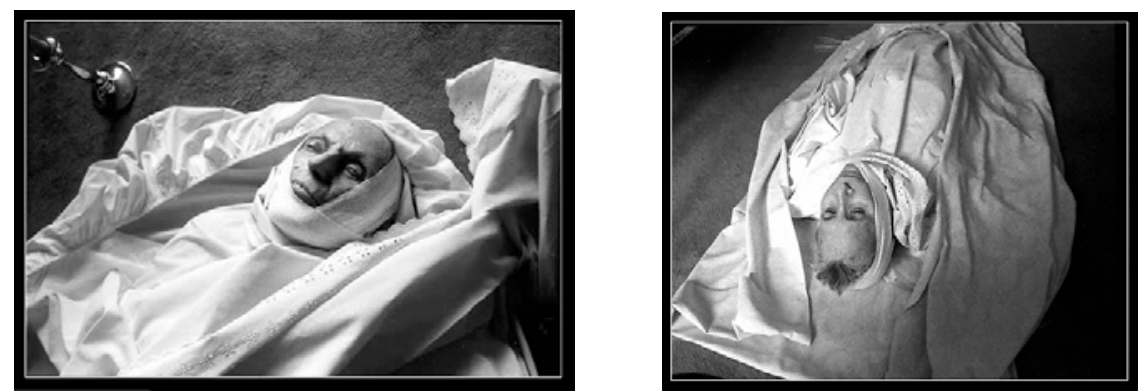

Figs. 34: pai de Pedro Meyer já falecido. Idem. 
Pode-se, agora, a partir da atuação de Meyer, especular sobre as consequências práticas de uma postura superficial, tomando-se, para isto, alguns pontos desenvolvidos nos capítulos anteriores. Aquilo que se falou sobre a dificuldade dos gêneros evidencia-se aqui: caberia, nesse trabalho, buscar classificação desse tipo? É fotojornalismo? São retratos? Antes de tudo, são imagens traumáticas, dentro dos termos de Barthes: cessam a linguagem e interrompem a significação. A significação aqui recai sobre a fotografia e não sobre o conteúdo das fotografias. Outro ponto a ser brevemente argumentado é que Meyer encontra uma relação com a tecnologia numa perspectiva de uso que confunde as relações aflitivas e afetivas: fotos jornalísticas (isentas, o olhar preparado para o flagrante, etc.) que se mesclam com fotos de família: seria esta a perspectiva de uso da tecnologia fotográfica na superficialidade?

Tais imagens foram publicadas em 1991, no formato de CD-ROM, apresentadas em slideshow narrado pelo proprio fotógrafo que, segundo o autor, teria sido o primeiro produzido somente com fotografias e som ${ }^{11}$. Com este trabalho, Meyer demonstra ter assumido imediatamente as possibilidades de atuação no universo digital, pois, apesar de as imagens de $/$ photograph to remember serem frutos de película, estariam somente disponíveis na mídia eletrônica.

Nascido em 1935, sua formação em fotografia deu-se na tecnologia tradicional dos filmes e laboratórios, o que torna curioso constatar a sua entrada imediata no digital, uma vez que Meyer sempre foi considerado um fotógrafo documentarista que flertava com os preceitos da straight photography para a construção de suas imagens.

E Meyer não se preocupa em esconder a sua manipulação digital que é bastante expressiva em sua obra, e muitas vezes propositadamente evidente, como a linha do asfalto na fotografia Emotional Crisis, ou não, como o out-door inserido na paisagem da mesma imagem; ou até polêmicas, como a perna do idoso que foi apagada da imagem original, como pode ser conferido em Retirement Community.

\footnotetext{
11 "By the way, this was the first CD ROM with continuous sound and images that had ever been produced anywhere"(Pedro Meyer no texto de apresentação de "I photograph to remember", no website www.zonezero.com).
} 


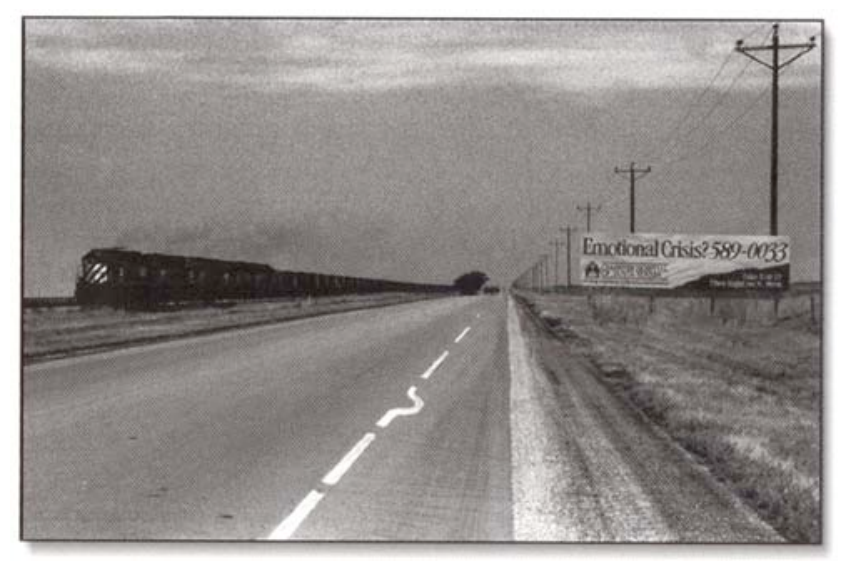

Fig. 35: "Emotional Crisis", Texas Highway, 1990/1993. In: MEYER, Pedro. Truths \& fictions: from documentary to digital photography. New York: Aperture,1995.

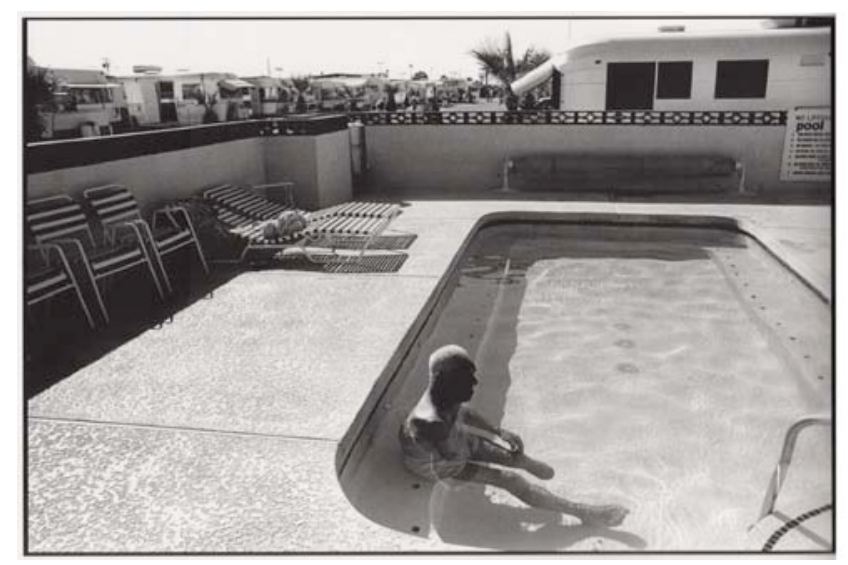

Fig. 36: Retirement Community, Yuma, Arizona, 1985/1992. In: MEYER, idem.

Muitas outras destas imagens, e as observações sobre a sua carreira como fotógrafo, podem ser encontradas em um de seus livros, Truth \& Fictions (1995) ${ }^{12}$. Curioso observar que coube a Joan Fontcuberta, autor citado anteriormente na discussão sobre a dificuldade dos gêneros, a redação do prefácio desse livro, intitulado Pedro Meyer: truths, fictions, and reasonable doubts. No texto, Fontcuberta revela que Meyer sempre responde da mesma maneira quando indagam sobre a sua guinada para o digital: "ele se vê como um fotógrafo documentarista, mas no sentido de documento como também uma interpretação do real"13. Se observado que documento é proveniente do latim documentum, derivação de docere "ensinar/demonstrar", ver-se-á que Meyer busca ainda explorar o potencial figurativo da fotografia, mas sem se submeter à autoridade de uma falsa ideia de isenção. Trata-se daquilo que Fontcuberta denomina como uma nova

\footnotetext{
12 MEYER, op. cit.

13 Idem, p. 9.
} 
consciência documental, capaz de ainda assim funcionar, mas liberta dos modelos que foram sendo sucessivamente construídos dentro de um mesmo modus operandi ${ }^{14}$.

Num certo sentido, tal nova consciência documental, isto é, tal forma de "demonstração" não se dá somente pela evidência do registro automático e supostamente isento, mas sim pela intensidade com que atinge os propósitos, não importando se, para isso, torne-se necessário violentar plasticamente as evidências ou até dramatizar a cena por meio das possibilidades que se mostram tão acessíveis no universo digital. Para Meyer, "sempre nos sentimos ameaçados quando nos deparamos com novas tecnologias e as mudanças que trazem", e deve-se receber tais mudanças "com cautela"; no entanto, não se pode permitir que "esta cautela se torne um obstáculo para expandirmos nossos horizontes"15. Essa postura fica clara em Truth \& ficctions, que tem como mote 0 embate entre a cultura norte-americana e a mexicana, que apresenta imagens que ora demonstram manipulação evidente, ora sugerem uma fotografia straight: oscilação que exige a nova consciência documental.

Tal "ficar à vontade" no ambiente digital, além de ser evidenciado por suas imagens, pode ser também notado no seu web site, "zone zero", quando abre espaço para que fotógrafos do mundo inteiro possam mostrar seus trabalhos e trocar experiências visuais. No texto de apresentação do site $^{16}$, Meyer avisa aos candidatos interessados em expor seus trabalhos, que 0 menos importante é o lugar que as imagens ocupam dentro da transição entre a fotografia tradicional e a digital, e a prioridade será dada para imagens que tenham mérito próprio e conteúdos capazes de inspirar os demais. Ressalta ainda que não será levado em conta 0 curriculum vitae do candidato, pois o objetivo do espaço é dar as mesmas condições de acesso a todos os participantes. Quando uma tela "se atualiza" em zonezero, tem-se ali exemplo claro de jogo na superficialidade. E isto fica mais evidente ainda quando Meyer usa a tela para a disponibilização de e-books: livros fotográficos em formato digital e que, por esta razão, podem ser adquiridos a preços bem menos custosos que os livros tradicionais.

\footnotetext{
14 "This is a consciousness that cries out its documentary nature, and is nevertheless capable of freeing itself from the modus operandi that has come to define successive documentary models" (idem, p. 8).

15 "A través de la historia, la gente siempre se ha sentido amenazada cuando se enfrenta con nuevas tecnologías y con los cambios que trae. Yo creo que debemos recibir dichos cambios con cautela, pero no debemos dejar que esa cautela obstaculize nuestra capacidad de expander nuestros horizontes"(idem, p.113).

${ }^{16}$ Disponível em http//:www.zonezero.com.
} 


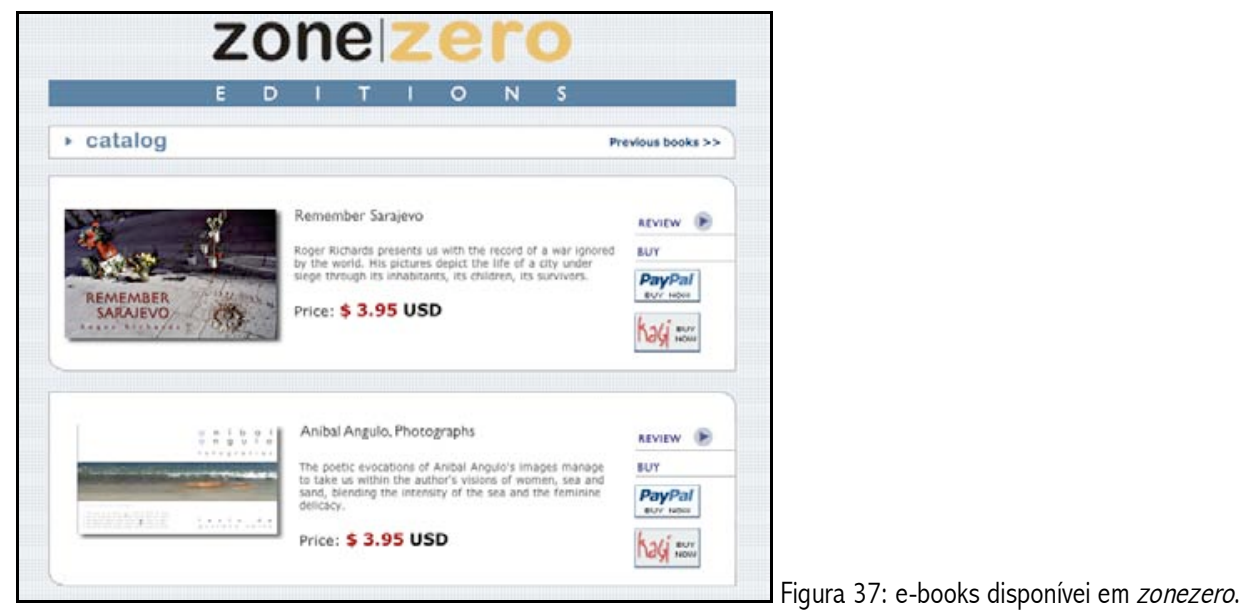

Mas apesar desses desmembramentos de sua atuação serem pertinentes para a argumentação, a proposta de I photograph to remeber ainda merece destaque especial por tornar mais evidente aquela equalização do ver que colabora para a mescla entre concreto e abstrato, e ainda sem a necessidade de se recorrer à manipulação digital. Ademais, este trabalho também mescla a fotografia tradicional e a fotografia digital, quando elege a tela como instância de apresentação de imagens obtidas com películas. Dessa forma, serve tanto como exemplo para a leitura da caixa preta (que aqui teve seu texto interpretado como sendo mais adequado à prática da fotografia com filme), quanto do elogio, pois assumir a dimensão da tela é um pouco assumir a superficialidade e o jogo da sociedade telemática que ora emerge.

Viver sobre a superficialidade é algo difícil de digerir, diz Flusser. Mas assumir tal postura é o que permitirá "captar as virtualidades revolucionárias" ${ }^{17}$ que, como aqui se afirma, o universo digital parece permitir com mais pertinência e fluidez. Pedro Meyer demonstra que esta dificuldade passa por essa nova consciência documental que parece ser exigida. É um pouco aquilo que foi apontado no capítulo anterior sobre o esforço que envolve 0 ato de se notar o caráter ficcional de qualquer documento e o caráter documental de qualquer ficção. 0 que está no centro do jogo são, portanto, as balizas pelas quais o homem vem se orientando na era moderna e que se esparramam nas superfícies das tecnoimagens contemporâneas. A confusão entre ficção e documento que as tecnoimagens promovem não mais admite que se proclame o que pode ser uma verdadeira forma de vivência, tal como Baudrillard e Debord se apressaram em definir. Assumir a superficialidade como novo modelo daquilo que se entende por real não significa assumir que a realidade concreta

\footnotetext{
${ }^{17}$ FLUSSER, Universo das imagens técnicas, op. cit., p. 91.
} 
não existe, mas sim assumir a realidade das tecnoimagens sem demonizá-las como aparência encobridora de uma ideia de verdade, termo este que talvez seja o mais "esparramado" de todos.

Observar com mais afinco tal dificuldade é o objetivo do próximo capítulo.

Por fim, resta apenas destacar a atuação de Pedro Meyer como um jogador que demonstra que algo difícil de digerir é algo doloroso, sobretudo se observada a densidade de I photograph to remember, e que, fazendo uso da fotografia, assumidamente se coloca diante da dor dessa tarefa. 


\section{A FOTOGRAFIA E O PENSAMENTO MAIS DIFÍCIL}

A "dificuldade de digestão" que Flusser atribui à superficialidade é obviamente pelo fato de esta ser experiência nova. Todo esse universo desenhado pelo filósofo permite uma aproximação com a fotografia para compreender seu papel social de forma mais fluída e imediata, por meio da apreensão desta nova roupagem tecnológica que se apresenta com o digital. A "nova consciência que emerge" talvez seja, portanto, mais a conscientização do papel efetivo da fotografia.

Questionar a fotografia, uma técnica impregnada de ciência, isto é, uma tecnologia, é questionar as referências modernas sobre o que é "verdadeiro ou falso", "real e aparente", retomando as palavras do filósofo, e que não fazem mais sentido agora imersos numa sociedade com tal capacidade de imaginação, principalmente quando essa capacidade de fabricar e se comunicar por meio de imagens se revela, aqui se assume, com mais evidência no universo digital. Portanto, a dificuldade que está no centro do jogo promovido pela tecnoimagem consiste no desconforto dessa revisão da postura soberana do homem científico, sujeito conhecedor, onde 
todo o resto é objeto. Na superficialidade, tudo ganha a mesma dimensão existencial, tudo passa a ser zero-dimensão e, por isto, nada mais desafiador do que perceber a possibilidade de ser pertinente a assertiva de que, hoje, "as imagens nos olham".

As tecnoimagens contemporâneas parecem promover com mais intensidade tal questionamento sobre o lugar do homem. Segundo Tomaz Tadeu e Silva ${ }^{1}$, "a subjetividade humana é, hoje, mais do que nunca, uma construção em ruínas", e afirma que hoje, o que emerge dessa "desavergonhada conjunção entre homem e máquina" é a dissolução da "singularidade e exclusividade do humano", o que obriga a não mais pensar "em termos de sujeitos, indivíduos, mas em termos de fluxos e intensidades". Cita a ontologia deleuziana para sustentar sua tese:

\begin{abstract}
(...) o mundo não seria constituído, então, de unidades (sujeitos), de onde partiriam ações sobre outras unidades, mas inversamente, de correntes e circuitos que encontram aquelas unidades em sua passagem. Primários são os fluxos e as intensidades, relativamente aos quais os indivíduos e os sujeitos são secundários, subsidiários. ${ }^{2}$
\end{abstract}

Com tais observações, pode-se dizer que as telas que promovem o fluxo incessante de tecno-imagens, correspondem ao grosso dessa corrente de circuitos, onde a câmera fotográfica, tornando-se cada vez mais apenas uma pequena tela, torna-se também uma porta de acesso a esta ubiquidade. A partilha sujeito/objeto, dessa forma, fica sem sentido, no entendimento mais restrito do termo: sem direção. 0 contexto audiovisual, como bem observa Muniz Sodré, é um novo bios, um novo ambiente em que as relações se dão de fato ${ }^{3}$, não cabendo mais questionar se são reais ou não, fazendo eco, assim, a Flusser, quando denunciou a fragilidade desses termos para avaliar o novo estado de consciência que emerge.

Vattimo, um dos que defendem o "fim" de uma era moderna, vê nessa multiplicação vertiginosa das tecnologias da comunicação "uma situação explosiva". Para o filósofo italiano, com a multiplicação das imagens pelo mundo perde-se o sentido de realidade, e é justamente nessa nova percepção de mundo, constituída por uma confusão cultural e uma comunicação intensificada, que reside 0 processo emancipatório do homem contemporâneo ${ }^{4}$. Para ele, a sociedade do espetáculo de Debord não seria somente a "sociedade das aparências manipuladas

\footnotetext{
${ }^{1}$ SILVA, Tomaz Tadeu da. Pedagogia dos monstros. Os prazeres e os perigos da confusão de fronteiras. Belo Horizonte: Autêntica, 2000, pp. 11-17.

${ }^{2}$ Idem, p. 16

${ }^{3}$ SODRÉ, Muniz. Entrevista. Revista Pesquisa Fapesp - Especial Revolução Genômica. São Paulo: FAPESP, setembro de 2008, pp.77-82.

${ }^{4}$ VATTIMO, Gianni. A sociedade transparente. Lisboa: Relógio d’Água, 1992, p. 17.
} 
pelo poder", mas "também a sociedade em que a realidade se apresenta com características mais brandas e fluidas, e em que a experiência pode adquirir os aspectos de jogo" 5 .

Jogo que, para Flusser, cabe lembrar, tende a ser percebido a partir do tédio gerado pela onipresença das tecnoimagens que copiam tudo, vale dizer, pela banalização da imagem; e também pelo abandono de uma ideia de sujeito como artista criador nos "moldes divinos" (este, que não deixa de ser a afirmação do sujeito moderno racional pela sua negação).

A vivência na superficialidade seria, dentro da tradição filosófico-ocidental moderna, mais o repouso do olhar e uma comunhão com as aparências, um estágio apenas inicial dentro de um projeto que busca a utilidade do pensamento humano num sentido de "ir além", um pensamento metafísico que encontraria na ciência um exercício constante de sua eficácia. Flusser afirmara, grosso modo, que o homem seria "libertado para a superficialidade" quando desprezasse o fio condutor da ciência, que significa desprezar, portanto, um modo específico de pensamento para daí emergir para um novo estado de consciência. Mas como comparar essas duas modalidades de pensamento?

Analisar a imagem sob uma perspectiva filosófica remonta quase sempre a Platão e ao seu mito da caverna, mito este que abriria as portas para o avilamento de toda aparência, vale dizer, desenharia a insuficiência do olhar para a definição de uma ideia de verdade. A aparência como vilã é que permite, por exemplo, Debord definir o seu espetáculo como o "herdeiro de toda a fraqueza do projeto filosófico ocidental, que foi um modo de compreender a atividade dominado pelas categorias do ver (...)" ${ }^{\prime 6}$. Sontag, ainda em Sobre fotografia, teria apontado que:

(...) a realidade sempre foi interpretada por meio das informações fornecidas pelas imagens; e os filósofos, desde Platão, tentaram dirimir nossa dependência das imagens ao evocar o padrão de um modo de apreender o real sem usar imagens." 7

Martin Heidegger afirmara que o platonismo teria inaugurado um modo de pensar técnico. Se quase todo questionamento contemporâneo que recai sobre a modernidade coloca Descartes como ponto de partida, como marco zero da ciência moderna, Heidegger encontra respaldo já no filósofo do mito da caverna, onde a busca pela profundidade das coisas, por aquilo que está por trás das aparências, teria começado a definir o pensamento do homem, em seus

\footnotetext{
${ }^{5}$ Idem, p. 65.

${ }^{6}$ DEBORD, op. cit., pp 14-19.

${ }^{7}$ SONTAG, Susan. op. cit., 2004, p. 169.
} 
passos mais iniciais, já como método científico. "0 próprio pensar é tido ali como uma téchne, 0 processo da reflexão a serviço do fazer e do operar."8 Para o filósofo, a ciência é o desdobramento da filosofia entendida como metafísica, e os avanços tecnológicos, cada vez mais automatizados, representariam o fim da tarefa da filosofia, uma vez que a técnica "passa a orientar todas as manifestações no Planeta e o posto que o homem nele ocupa"9.

Quando decreta o fim da filosofia nas ciências tecnicizadas, Heidegger busca preservar uma última possibilidade para o pensamento que, para ele, não teria fundamento nem metafísico nem científico. Mas que tarefa estaria reservada a este "desconcertante" pensamento que não pode ser nem metafísica, nem ciência, indaga o filósofo?

0 fim para Heidegger é, na verdade, o mesmo que "acabamento". Por isto, tal constatação sobre o fim da filosofia não aponta a sua ruína, a pura cessação de um processo; esse fim representa a possibilidade de "concentração nas possibilidades supremas"10. Um pensar que não é técnico-cientifico nem metafísico é um pensar num estado mais original do termo, o pensamento mais singelo; porém, o mais difícil, por estar fora dos componentes racionais e irracionais, tal como o autor descreve abaixo:

"Talvez exista um pensamento mais sóbrio do que a corrida desenfreada da racionalização e o prestígio da cibernética que tudo arrasta consigo. Justamente esta doida disparada é extremamente irracional. Talvez exista um pensamento fora da distinção entre racional e irracional, mais sóbrio ainda do que a técnica apoiada na ciência, mais sóbrio e por isso à parte, sem a eficácia e, contudo, constituindo uma urgente necessidade provinda dele mesmo."11

A tese aqui proposta é que este pensamento mais difícil apontado por Heidegger é passo fundamental para o "nível de consciência novo" que a superficialidade exige, visto que tal pensamento é a superação da postura metafísica, pois surgirá a partir de nova postura perante as imagens. Em outras palavras, a tecnoimagem representa a possibilidade de uma filosofia de outra ordem, mas que já poderia, de início, ser delineada como antiplatônica: a priorização da aparência em detrimento da profundidade, e isso é, sob muitos aspectos, o próprio elogio da superficialidade.

\footnotetext{
${ }^{8}$ HEIDEGGER, Martin. Sobre o Humanismo. In: Conferências e escritos filosóficos. São Paulo: Abril Cultural, 1979, p. 150.

${ }^{9}$ Idem. 0 fim da filosofia e a tarefa do pensamento. In: idem, p. 73.

${ }^{10}$ Idem, p. 72.

${ }^{11}$ Idem, p. 81.
} 
Dentro do projeto filosófico de Flusser, já foi apontado que a ciência ocupa lugar estratégico na definição da tecnoimagem. Sabe-se que a ciência é fruto da dúvida metódica que se consagra pelo cartesianismo: o "penso, logo existo" coloca tudo em dúvida, menos o homem; questiona a existência de tudo, mas protege o homem deste questionamento. Como bem observa Gustavo Bernardo, trata-se de uma compensação psicológica: "a confiança na solidez metafísica do ego pensante cresce na razão inversa da perda da confiança na realidade"12.

Isto posto, e agora tomando o raciocínio de Flusser, a tecnoimagem, como texto científico apurado seria, de imediato, a consagração deste modo de pensar cartesiano, pois é fruto da ciência moderna, mas por se tratar de imagem, foge da linearidade do texto que a gerou e promove a possibilidade do "vaguear circular do olhar", o "tempo do eterno retorno" ou o "tempo de magia", teria dito ${ }^{13}$. Por isso caberia à tecno-imagem a função de "remagicizar" a linearidade do texto científico - este o resultado de postura metafísica, no entendimento de Heidegger (ciência como platonismo); em outras palavras, a tecnoimagem é movimento contrário na história da filosofia ocidental: busca-se a aparência das profundezas, e não a profundidade das aparências.

No entanto, se como afirma Stein, "é tarefa primordial da filosofia conduzir o homem para além da imediatidade e instaurar a dimensão crítica"14, seria a tecnoimagem e sua dimensão filosófica um regresso, o engessamento do potencial crítico do homem? É a inquietude promovida por essa questão que faz Flusser admitir que o futuro pode ser "simultaneamente aterrador e inebriante"15. Tomando-se os termos de Língua e realidade, o futuro será aterrador se 0 pensamento da humanidade for substituído e conduzido pela automação tecnológica, transformando-a num "a gente inautêntico", numa "conversa fiada"; inebriante, se essa automação tecnológica deslocar a humanidade para a camada criativa, para a "poesia", o que permitirá a sua realização plena ${ }^{16}$. Mas não seria a tecno-imagem um código que já traz em sua estrutura a inflexão dessas duas possibilidades?

\footnotetext{
${ }^{12}$ BERNARDO, Gustavo; FINGER, Anke; GULDIN, Rainer. Vilém Flusser: uma introdução. São Paulo, Annablume, 2008, p.111.

${ }^{13}$ FLUSSER, Filosofia da caixa preta, p. 8.

${ }^{14}$ STEIN, Ernildo. Nota do Tradutor. In: HEIDEGGER, Conferências e escritos filosóficos, op. cit., p. 27.

${ }^{15}$ FLUSSER, Universo das imagens técnicas, op. cit., p. 38.

${ }^{16}$ FLUSSER, Lingua e realidade, op. cit., p. 150.
} 
A tecnoimagem é filosofia de outra ordem por ser linguagem de outra ordem. Heidegger diz que a linguagem foi muito cedo aprisionada pela lógica e pela gramática ${ }^{17}$. Por isto as suas "terminologias bizarras" que desafiam a compreensão que está dentro deste aprisionamento: "ser-aí", "ser-para-a-morte", "ser-no-mundo", "ser-adiante-de-si", são alguns dos termos que compõem o cerne de sua filosofia, pois remetem a uma tentativa de se atingir o estado originário da linguagem, longe das amarras da gramática. Afirma: "Se aqui somos obrigados a introduzir expressões pesadonas e talvez nada bonitas, não é brincadeira minha nem preferência especial por uma terminologia própria, mas é a coerção dos próprios fenômenos"18. Também quando Heidegger diz que a língua alemã é mais apropriada para a filosofia, por ser decendente da língua grega, não se trata de provincianismo ${ }^{19}$, mas sim de provocar este retorno aos gestos iniciais da linguagem, que é a tentativa de assimilar tal "coerção dos fenômenos".

Num certo sentido, Flusser revela que esse aprisionamento pode ter chegado ao fim pela tecnoimagem, por mais paradoxal que pareça, já que a tecnoimagem é fruto de texto (lógica e gramática aprimoradas, isto é, a ciência). 0 embate entre texto e tecnoimagem ganha contornos mais expressivos com Roland Barthes, o que já foi detalhado no capítulo 5. Cabe apenas ressaltar que esse embate pode ser encarado como eixo principal de sua análise em $A$ câmara clara ${ }^{20}$, que demonstra a constatação da insuficiência do texto para lidar com a imagem. Jay Prosser, em seu ensaio Buddha Barthes: what Barthes saw in photography (that he didn't in literature), afirma que A câmara clara não aborda somente a fotografia, mas também os "limites da palavra" ${ }^{21}$. Com sua conclusão calcada na ideia de que a fotografia está entre a loucura e a sensatez, Barthes demonstra como a fotografia se posiciona entre o racional e o irracional e, por isso, pode ser ambiência para o "pensamento mais difícil". E a partir daí pode-se inclusive estender à todas as fotos aquele conceito de foto traumática desenvolvido em $A$ mensagem fotográfica22: quando

\footnotetext{
17 "Mas nisto não se deve esquecer que 'sujeito' e 'objeto' são expressões inadequadas da Metafísica, que se apoderou muito cedo da interpretação da linguagem, na forma de 'Lógica' e 'Gramática' ocidentais." HEIDEGGER, Sobre o humanismo; in: Conferências e escritos filosóficos, op. cit., p.149.

${ }^{18}$ HEIDEGGER, Martin apud SAFRANSKY, Rudiger. Heidegger: um mestre da Alemanha entre o bem e o mal. São Paulo: Geração Editorial, 2005, p. 195.

19 É recorrente tal crítica à postura do filósofo. Cabe, como exemplo, citar Álvaro Vieira Pinto: "valendo-se da capacidade de que se tornou profissional no campo da especulação e das 'pesquisas' filosóficas, da sua consumada habilidade de pelotiqueiro na manipulação dos elementos componentes das palavras, em grego, latim, ou alemão - o que reduz quase interiramente o seu pensamento a se apoiar sobre o puro acidente das etimologias (...)." In: PINTO, op. cit., p.150.

${ }^{20}$ BARTHES, A câmara clara, op. cit.

${ }^{21}$ In: BATCHEN, Geoffrey. Photography Degree Zero: reflections on Roland Barthes's Camera Lucida. Massachusetts: MIT Press, 2009, p. 91.

22 In: BARTHES, 0 óbvio e o obtuso, op. cit., pp. 21-25.
} 
apontara as imagens de violência e catástrofes como insignificantes no sentido de não permitirem nenhuma "categorização verbal" que pudesse influir no processo de significação, Barthes evidenciava certa deficiência de uma linguagem "aprisionada pela lógica e pela gramática", tal como asseverado aqui por Heidegger.

Assertiva crucial, valiosa e decisiva de Régis Debray: "A infância do signo é o futuro do signo "23. Aqui também tem-se, aparentemente, um paradoxo, mas que revela que 0 amadurecimento da linguagem tem na sua dimensão originária o seu mais alto grau de atuação efetiva, e que a escrita, a gramática, a lógica - o logos, vale dizer - nada mais são do que tentativas de se mapear e domar esse momento soberano da linguagem. De forma que as tecnoimagens, ao ocuparem nível ontológico à frente das imagens tradicionais e da escrita, estariam mais próximas de tal dimensão, isto é, próximas do "futuro", que é a "infância" do signo, para se ficar nos termos de Debray. E retomando Heidegger, o pensamento mais difícil seria reconhecer esse momento que, para ele, é o reconhecimento da dimensão existencial do homem em seu estado mais originário.

Visto desta forma, constata-se que a história da filosofia no Ocidente foi, de certa maneira, a história do homem afastando-se desta dimensão originária, que não o tinha como medida para todas as coisas: uma instância em que não há a partilha sujeito/objeto e, por isto, uma situação cada vez menos provável na medida em que a ciência avançava.

É essa condição original que motiva Heidegger à construção de seus termos em que sujeito e objeto coexistem, onde o mundo não existe porque "primeiro o ser humano o contempla até no sentido da concepção", mas "muito antes, é o ser humano que é contemplado"24: assumir que as tecnoimagens olham os sujeitos é um pouco assumir essa possibilidade de ser contemplado pelo mundo. Tal filosofia inversa das tecnoimagens (retorno às aparências) opera, portanto, nesse questionamento do sujeito moderno que ainda tenta se impor no mundo.

Nessa perspectiva da fotografia como filosofia, cabe notar que Henri Van Lier teria proposto algo similar em seu Philosophie de la photographie ${ }^{25}$, em1981. Também propõe 0 abandono da linguística como modelo interpretativo, fazendo coro à mesma deficiência da semiologia que foi denunciada por Barthes, enxergando na fotografia o potencial de articulação

\footnotetext{
${ }^{23}$ DEBRAY, op. cit., p. 287.

${ }^{24}$ HEIDEGGER, Martin apud SAFRANSKY, Rudiger. Op. cit., p. 349.

${ }^{25}$ Aqui utiliza-se a versão em inglês. LIER, Henri Van. Philosophy of photography. Leuven: Lieven Gevaert Research Center, 2007.
} 
com a linguagem num estado mais originário ${ }^{26}$. Todavia, como ele mesmo assume, sua concepção de filosofia estaria sendo tomada no sentido mais comum do termo, num mesmo nível científico que, por exemplo, a psicologia, sociologia ou antropologia ${ }^{27}$.

Tal constatação presume a filosofia como nova forma de conhecimento, isto é, como ciência. Mas não é o caso aqui: essa potência filosófica que se pensa poder atribuir à fotografia não é busca de conhecimento objetivo, é como apontado anteriormente, movimento inverso, antiplatônico. Observe-se a proposição de Heidegger:

Pois a filosofia não é precisamente ciência, nem mesmo a ciência mais pura e rigorosa. A única coisa que podemos dizer é: o que a ciência é por sua parte reside na filosofia em um sentido originário (...) filosofia é em verdade origem da ciência. Exatamente por isso, contudo, ela não é ciência - não sendo também ciência originária ${ }^{28}$.

Atribuir à fotografia o caráter de filosofia, esta entendida pelos termos de Heidegger, é atribuir-lhe um sentido originário para a linguagem, sentido este que não se sustenta pela verbalização ou escrita: é assumir a sua insignificância (sem significado) dentro da lógica formal. Trata-se de uma forma mais próxima do ato de se "pensar algo", ao invés de se "pensar sobre algo". 29

Nas muitas obras que aqui serviram de apoio para a investigação do pensamento do filósofo não se vê qualquer menção à fotografia com esse potencial; para ele, era a poesia, principalmente, que permitiria tal articulação (a obra de arte em geral, na verdade, mas não afirma expressamente a fotografia, ou o cinema, e sim, além da poesia, a arte pictórica, a escultura e a música $)^{30}$. Pelo contrário, pois se observada toda a sua argumentação sobre os fundamentos da ciência moderna em Platão, ver-se-á que o embate com a aparência se torna 0 pilar sustentador da ascensão do homem como sujeito. Para Heidegger, "a transformação do mundo em imagem e do homem em sujeito" é o "entrelaçamento decisivo para a época moderna", configura a essência moderna. "No instante em que o mundo se torna imagem, a posição do

\footnotetext{
26 "We therefore do not have the words to describe a photography adequately. But specialized terminology would be even more fallacious, as only common language has the power - through its bricolage - to re-encode itself so as to touch on new objects. That is why one should forget all jargon here, and particularly that of linguistics." (idem, p. 9)

27 "Self-evidently, the term philosophy is here taken in its most common meaning. A psychology, sociology or anthropology of the photograph would have been equally suitable" (idem).

${ }^{28}$ HEIDEGGER, Martin. Introdução à filosofia. São Paulo: Martins Fontes, 2008, p. 20.

${ }^{29}$ ARENDT, Hanna. Martin Heidegger at eighty. In: MURRAY, M. Heidegger and the modern philosophy. New Haven e London: Yale University Press, 1978, p. 296.

${ }^{30}$ HEIDEGGER, Martin. A origem da obra de arte. Lisboa: Edições 70, 2007.
} 
homem se torna visão do mundo"31, afirma o filósofo, e tal postura ganha na antropologia a sua consagração:

\begin{abstract}
A antropologia é a explicação do homem que, no fundo, já sabe o que o homem é e, portanto, nunca poderá perguntar quem ele é. Pois a antropologia teria de reconhecer, ao fazer a pergunta, que foi abalada e superada. Como se pode esperar que ela o faça, quando sua tarefa própria e exclusiva é a confirmação retroativa da certeza de si do subjectum? ${ }^{32}$
\end{abstract}

Quando afirma ainda que "visão de mundo passa a ser o nome para a posição do homem no meio do ente", poderia até se concluir que situar a fotografia como "pensamento de nova ordem" que supera o pensamento moderno seria uma aberração, uma vez que ela consagra e, de certa forma, metaforiza a ideia de "visão de mundo". No entanto, a fotografia, como tecnoimagem, parece ameaçar aquele "entrelaçamento decisivo" (mundo como imagem=homem como sujeito), e as análises de Barthes e Flusser são preciosas para esta constatação: a "intratável realidade" que surge com a fotografia, fruto de sua objetividade técnico-científica, abala essa "visão de mundo" ao configurar nova ordem de aproximação, o que é o mesmo que nova ordem de abstração, pois toma-se nova distância; e ainda, cabe ressaltar, num movimento inverso de não mais abstrair o concreto, mas sim, concretizando o abstrato. Deve-se relembrar outra pontuação de Barthes: a fotografia representaria uma revolução antropológica na história do homem, uma vez que seu caráter específico revelaria um tipo de consciência implícita sem precedentes.

Tal consciência implícita na fotografia é a nova consciência que emerge na superficialidade, e a dificuldade de digestão surge pelo reflexo do abalo nessa "visão de mundo", o que é o mesmo que abalar o homem como sujeito. Para Flusser, "já que fomos projetados por esse conjunto, já que existimos nele e graças a ele, é tremendamente difícil imaginarmos outro projeto existencial, no qual a nefasta divisão matéria-espírito não seria o caso"33. A fotografia e as tecnoimagens parecem facilitar essa forma de reflexão. Não se trata mais de a fotografia ser 0 espelho do real (objeto), mas o espelho da posição do homem (sujeito). Segundo ainda Flusser, a reflexão é "movimento inverso do pensamento, que o controla e o decompõe em seus elementos", e o "método desse compreender-se e modificar-se do pensamento é a filosofia". E aqui não se

\footnotetext{
${ }^{31}$ Idem. A época das imagens de mundo. Disponível em: http://ateus.net/artigos/filosofia/a_epoca_das_imagens_ de _mundo.php. Acesso em novembro de 2009.

${ }^{32}$ Idem.

${ }^{33}$ FLUSSER, Vilém. Da religiosidade: a literatura e o senso de realidade. São Paulo: Escrituras, 2002, p. 40.
} 
deixa de fazer eco à Heidegger: "a filosofia é portanto exatamente o contrário da ciência e da tecnologia"34.

0 caráter híbrido das tecno-imagens, que operam com a confusão entre arte e ciência, e por esta razão causa ruído incontornável nas acepções de ciência e tecnologia, sugere, portanto, possibilidade de filosofia nesse sentido mais originário: parece, enfim, facilitar a operação de se pensar em um projeto existencial sem a "nefasta divisão matéria-espírito". Ainda Flusser: "não é com mais ciência e tecnologia que sairemos da situação angustiada na qual nos encontramos, mas com mais filosofia"35.

"A imagem me olha", diz-se por aí, e isto revela que a "visão de mundo" torna-se "visão do mundo", o que nada mais é do que o sujeito olhando para o homem que é, questionando a certeza de si, se "autoantropologizando", este sempre o pensamento mais difícil. Quer-se dizer que a fotografia e todo 0 universo desenhado pelas imagens técnicas não somente afastam 0 homem de si; pelo contrário, pode também realizar essa aproximação de forma constante, insuportável e angustiante. Observar tal angústia e sua relação com a fotografia contemporânea é o objetivo do último capítulo.

\footnotetext{
${ }^{34}$ Idem, p. 41.

${ }^{35}$ Idem.
} 
$\mathrm{Na}$ convivência com esse "caos" comunicacional de Vattimo, isto é, com o bombardeamento incessante de imagens nas múltiplas telas, é bastante comum afirmar-se a angústia como um estado de consciência habitual, que também poderia até ser encarada como uma evolução natural do tédio apontado por Flusser que, é gerado pela "(...) nossa cobiça por sensações (queremos imagens novas toda noite) (...)"1. Angústia que é gerada, portanto, pelo fluxo contínuo de dados disponibilizados dentro de uma dinâmica que torna impossível a apreensão de grande parte das informações, denunciando uma certa impotência do homem para lidar com tamanha demanda. Tal angústia, se encarada como sintoma da superficialidade, começa a revelar que mesmo num processo de "emancipação", tal como Vattimo acredita poder ser possível atribuir às tecnologias da comunicação contemporânea, o desconforto e a dificuldade são inevitáveis.

Angústia é um termo-chave dentro do pensamento de Heidegger, sobretudo para compreender a possibilidade daquele retorno a um estado mais originário, o que aqui se afirma como o "pensamento mais difícil". Segundo Heidegger, a angústia é um estado de consciência em que o homem se torna indiferente à vida cotidiana, onde o nada se torna o mesmo que tudo, pois

\footnotetext{
${ }^{1}$ FLUSSER, 0 universo das imagens técnicas, p. 62.
} 
tudo parece perder a importância, inclusive o próprio eu. A angústia é o que revela o nada, termo precioso para Heidegger: "Sem a originária revelação do nada não há ser-si-mesmo, nem liberdade". ${ }^{2}$ A possibilidade da liberdade surge quando "estamos suspensos no nada".

Rudiger Safransky, em sua biografia de Heidegger, traz uma síntese bastante precisa ao formular que "no medo do vazio perdemos um mundo e mesmo assim vivenciamos como do nada sempre nasce outro mundo", e completa: "através da angústia podemos vir ao mundo outra vez". ${ }^{3}$

Para Flusser, o nada é sempre referência na definição do papel das tecnoimagens: a zerodimensionalidade, a possibilidade de construção a partir de cálculos (as pedrinhas soltas do fio da ciência), seriam uma forma de encobrir o "absurdo do nada". Juntam-se os pontos, criamse imagens para disfarçar os intervalos que denunciam tal absurdo. Flusser interpreta o "nada" como circunstância sem sentido, que não aponta direção; por isto, absurdo: tecnoimagem é forma de "dar as costas ao nada, para orientar-se no universo" 4 . Aqui, surge uma complementação entre Heidegger e Flusser na exploração do "nada", que vale a pena ser examinada, mesmo que brevemente, tanto para incrementar as reflexões a respeito da superficialidade, quanto para a compreensão do pensamento de Heidegger.

Em sua autobiografia, Flusser revela que a vinda para o Brasil o teria deixado "sem chão", "sem fundamento". Em Praga, com a invasão do nacional-socialismo, "a aceitação da realidade passava a ser um problema, pois tudo (família, amigos, faculdade, filosofia, arte, planos para o futuro) devia ser aceito como ilusão, e a realidade era o fato da morte violenta iminente"5; já no Brasil, com a ideia do suicídio à espreita, seria necessário buscar método para "deixar de pensar para poder viver novamente". Flusser diz que, sob tais circunstâncias, buscava "distância dos próprios pensamentos", indagava-se sobre a possibilidade de "viver do outro lado deles"6. 0 esforço se concentrava na tentativa de ser o sujeito do próprio pensamento, e não o objeto: agir e se ver agindo. Tais possibilidades é que definem, para Flusser, o "passo para trás de Heidegger"7. Se interpretado pelos termos deste filósofo, poder-se-ia dizer que, durante seus

\footnotetext{
${ }^{2}$ HEIDEGGER, Martin. 0 que é metafísica?. In: Conferências e escritos filosóficos, op. cit., p. 41.

${ }^{3}$ SAFRANSKY, op. cit., p.222.

${ }^{4}$ FLUSSER, $O$ universo das imagens técnicas, op. cit., p. 46

${ }^{5}$ FLUSSER, Vilém. Bodenlos, op. cit., p. 29.

${ }^{6}$ Idem, pp. 48-49.

${ }^{7}$ Idem.
} 
anos iniciais no Brasil, Flusser estaria suspenso no "nada" heideggeriano, como o título de sua autobiografia denuncia claramente: Bodenlos (sem chão).

Sua experiência do "nada", porém, mais define uma possibilidade absurda de vivência do que representa uma possibiidade de abertura. Tal conflito fica mais evidente quando se toma Vicente Ferreira da Silva como interlocutor. Este filósofo brasileiro, que se dedicava ao pensamento de Heidegger, tinha Flusser não só como amigo, mas também como opositor em relação à interpretação do "passo para trás" heideggeriano: o que para Flusser significava "passo em direção ao absurdo do nada" (o que afirmava com propriedade, pois teria, em suas palavras, "passado pelas consequências concretas" destes pensamentos), para Vicente Ferreira da Silva significava "passo em direção à Proximidade do Sacro", à "plenitude do Ser", tal como narrado em Bodenlos 8 .

Existe uma aparente contraposição entre Flusser e Heidegger quanto ao nada: o que para o primeiro é condição absurda de vivência, para o segundo é condição fundamental para se chegar a uma vivência legítima; para um, deve-se dar as costas ao nada; para o outro, deve-se encará-lo.

A técnica fotográfica parece servir mais aos propósitos de Heidegger do que aos de Flusser, ou seja, esse "nada" é mais evidenciado do que encoberto pela fotografia. "A filosofia deve primeiro provocar terror no ser humano" para "forçá-lo a recuar para aquele desamparo", diz Heidegger, do qual o ser humano sempre foge quando se volta para a cultura ${ }^{9}$. A fotografia, como "filosofia inversa", pode ser porta de acesso que fica entre "a sala do desamparo" e a "sala da cultura", quer-se dizer aqui. E tal constatação não invalida as virtudes da supeficialidade de Flusser, mas, como já visto, demonstra aquela dificuldade de digerir este novo estado de consciência apontado por ele: "As imagens técnicas vitoriosas, estas imagens em parte produzidas por nós mesmos, evoca em nós a sensação espectral do vazio". 10

E a perspectiva da fotografia ser "técnica da angústia" ganha mais incremento se levarmos em conta algumas das reflexões que Heidegger teceu sobre a técnica moderna.

Em sua conferência "A questão da técnica" (1953) ${ }^{11}$, sua intenção era tentar apontar como se dá, essencialmente, a relação entre o homem e o mundo a partir das conquistas

\footnotetext{
${ }^{8}$ Idem, pp. 110-115.

9 HEIDEGGER apud SAFRANSKY, op. cit., p. 231.

${ }^{10}$ FLUSSER, Universo das imagens técnicas, op. cit., p.87.

${ }^{11}$ HEIDEGGER, A questão da técnica, op. cit.
} 
estabelecidas pela ciência e sua consequente instrumentalização técnica. Em linhas gerais, Heidegger inicia sua tese ao sinalizar que técnica "não é meramente é um meio", é também um "modo de desabrigar"12. 0 homem moderno, por intermédio de seus instrumentos, passou a requerer este desabrigar da natureza na forma de desafio e não na forma de um "deixar acontecer". Segundo Heidegger, ao contrário da techné grega que se aproximava de um modo de intervenção do homem em que há uma continuidade entre a produção natural e a interferência humana, a técnica moderna opera num sentido em que a natureza é desafiada, calculada e armazenada como provisão. Como exemplo para o primeiro caso, Heidegger aponta os antigos moinhos de vento, em que "suas hélices giram familiarizadas ao seu soprar"13, não retirando, no entanto, a energia da corrente de ar para armazená-la; para o segundo caso, o filósofo cita as usinas hidroelétricas que alteram o curso dos rios e reconfiguram paisagens. Nesse movimento de desafio e estocagem, o homem passaria a calcular a natureza, gerando assim a busca constante da precisão técnica por meio da própria técnica, comprometendo a autenticidade de seu papel neste processo.

Sendo a fotografia uma técnica moderna, o que ela desafia? 0 que a fotografia estoca? Ela não intervém concretamente na natureza, a não ser simbolicamente, e isto constitui o seu caráter pós-industrial. A única natureza que ela parece desafiar, portanto, se apresentada como técnica no entendimento de Heidegger, é a natureza humana. Um desafio que se torna cada vez mais incontornável para 0 homem contemporâneo, primordialmente pela constatação da onipresença das tecnoimagens na superficialidade.

Flusser disse que as tecnoimagens são superfícies que se condensam sobre o "abismo da zero-dimensionalidade" para escondê-lo ${ }^{14}$. Mas o que se propõe aqui é que as tecno-imagens, que tudo projetam, não escondem o nada, também o projetam. Esse mesmo abismo, numa análise de Heidegger ${ }^{15}$, é aquele sobre o qual pode existir uma ponte com extremidades firmes na terra, e caberia ao homem atravessá-lo e preservar-se; no entanto, tal ponte só surge à medida que 0 homem caminha. Em outras palavras, afirma-se aqui que a superficialidade promovida pelas tecnoimagens, sugere uma vivência que mantém o homem sempre consciente do abismo do nada que está sob seus pés.

\footnotetext{
12 Idem, p. 380.

${ }^{13}$ Idem, p. 381.

${ }^{14}$ FLUSSER, Vilém. Universo das imagens técnicas, op. cit., p. 23.

${ }^{15}$ SAFRANSKY, Heidegger, op. cit., pp 497-498.
} 
Cabe explorar a relação da fotografia com esse nada.

"Se algo não pode ser usado para mentir, então não pode também ser usado para dizer a verdade: de fato, não pode ser usado para dizer nada". ${ }^{16} \mathrm{~A}$ assertiva de Humberto Eco, apesar de aqui estar descontextualizada de sua abordagem semiótica, torna-se valiosa para dar seguimento à argumentação que vem sendo desenvolvida.

0 compromisso com a verdade que se atribuiu à fotografia desde o seu surgimento encontra sustentação nas suas raízes técnico-científicas que a tornaram testemunha de tudo. A recíproca também é verdadeira: se serviu para apontar a verdade, também serviu para mentir. No entanto, dada a fragilidade desse caráter com que vem sendo promovida pelo universo digital, a fotografia tende a nos mostrar sua incapacidade para dizer a verdade e, consequentemente, também para mentir; ou seja, nos evidencia a sua vocação para "nada". Mas numa perspectiva de atuação filosófica, cabe adequar este "servir para nada" como "servir ao nada".

Constatar tal servidão ao nada, e a presença da angústia na superficialidade, é o mesmo que constatar o esgotamento da fotografia para jogar com uma idéia de verdade. Parece, então, que foi atingido aquele patamar onde tudo já foi fotografado e videoteipado, e o tédio espreita quem ousa operar os aparelhos fotográficos. As motivações para muitos não seriam mais as evidências, portanto, mas o seu contrário: as fotografias tendem a operar numa esfera mais enigmática, mais provocadora, mais angustiante -seria o termo que melhor cabe aqui-, dadas as reflexões desenvolvidas a partir de Heidegger.

De forma que se a história da fotografia continua o mesmo que a "história-através-dafotografia", as cenas tendem a não mais apontar o mundo, mas mundos. E o digital trouxe uma espontaneidade e uma imediatidade para ambientar a fotografia que não mais a situa somente como contadora de grandes histórias, mas de pequenas também, e que beiram a banalidade.

Tal perspectiva, a despeito de mais evidente no universo digital das telas, sempre esteve presente no caminhar tecnológico da fotografia; mas, o que parece, em muitos destes momentos não eram encaradas como imagens que serviam ao nada, mas imagens que para nada serviam. Pode-se inferir que tais imagens passaram despercebidas porque o processo de registro de tudo ainda estaria em desenvolvimento, e toda imagem que não buscasse objetividade, isto é, que não buscasse evidenciar os grandes fatos do mundo, cairiam naquela "vala comum do esquecimento" (que tanto seduz Rosângela Rennó, oportuno lembrar).

\footnotetext{
${ }^{16}$ ECO, op. cit., p. 4.
} 
Robert Flynn Johnson resgatou diversas imagens produzidas sob tal perspectiva na obra Anonymous: enigmatic images from unknown photographers ${ }^{17}$. É verdade que Johnson encontra na arte contemporânea o respaldo necessário para sustentar sua busca; tenta, portanto, contemporizar as imagens como arte de vanguarda para a época. Mas não há nomes, são anônimos, a "sacralização do eu" apontada por Debray não se sustenta ali; não seria preciso recorrer à arte para justificar a empreitada de Johnson, se já se encaram tais fotografias dentro da perspectiva da superficialidade. Nessas imagens, qualquer discurso de estética é só mais um modo de tentar domar aquele "terror da polissemia", um modo de evitar o trauma do confronto com o nada que trazem.
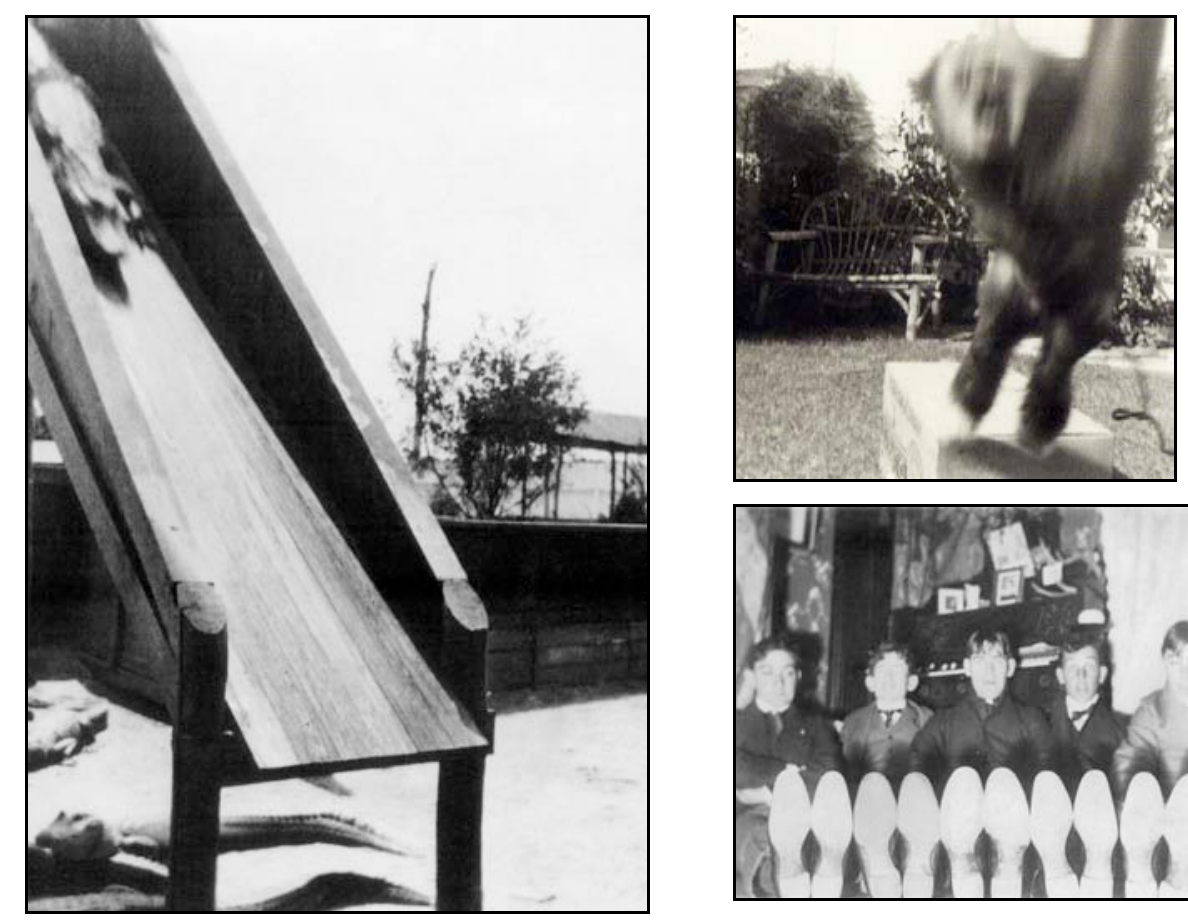

Fig. 38: imagens de anônimos nos séculos XIX e XX.

Quando a fotografia opera nessa instância mais enigmática de relação com o mundo, de forma quase espontânea, seu potencial filosófico parece tornar-se mais expressivo, pois para 0 nada aponta. Não teria sido essa a razão para o impacto das imagens de Eugène Atget na história da fotografia? Suas imagens documentais de Paris foram sistematicamente obtidas dentro de uma perspectiva mais despojada das referências estéticas da prática fotográfica da época, que

${ }^{17}$ JOHNSON, Robert Flynn. Anonymous: enigmatic images from aunknown photographers. New York: Thames \& Hudson, 2004. 
ainda eram muito ainda centradas na rivalidade com a arte pictórica (seja o pictorialismo ou 0 movimento da straight photography). 0 fato de suas imagens ganharem evidência somente em época posterior revela que, de certa forma, no momento de sua produção, tais imagens serviam para nada. 0 potencial filosófico que Atget teria explorado somente seria evidenciado nas entranhas dos movimentos artísticos de vanguarda que tiveram grande expressividade na história da $\operatorname{arte}^{18}$. É, inclusive, Salvador Dali que dirá que a fotografia, pelo "simples fato de transpor algo que é visto para uma imagem fotográfica, já implica uma invenção: o registro de uma realidade imprevista"19.

A possibilidade de retomar a história da fotografia sob uma perspectiva filosófica, e não estética, pode revelar que suas imagens objetivas já ganhariam acento expressivo sem a necessidade de se recorrer à escolas artísticas ou gêneros para a sua classificação. É o que nos prova a investida de Robert Flynn Johnson e a "descoberta" tardia de Eugène Atget.
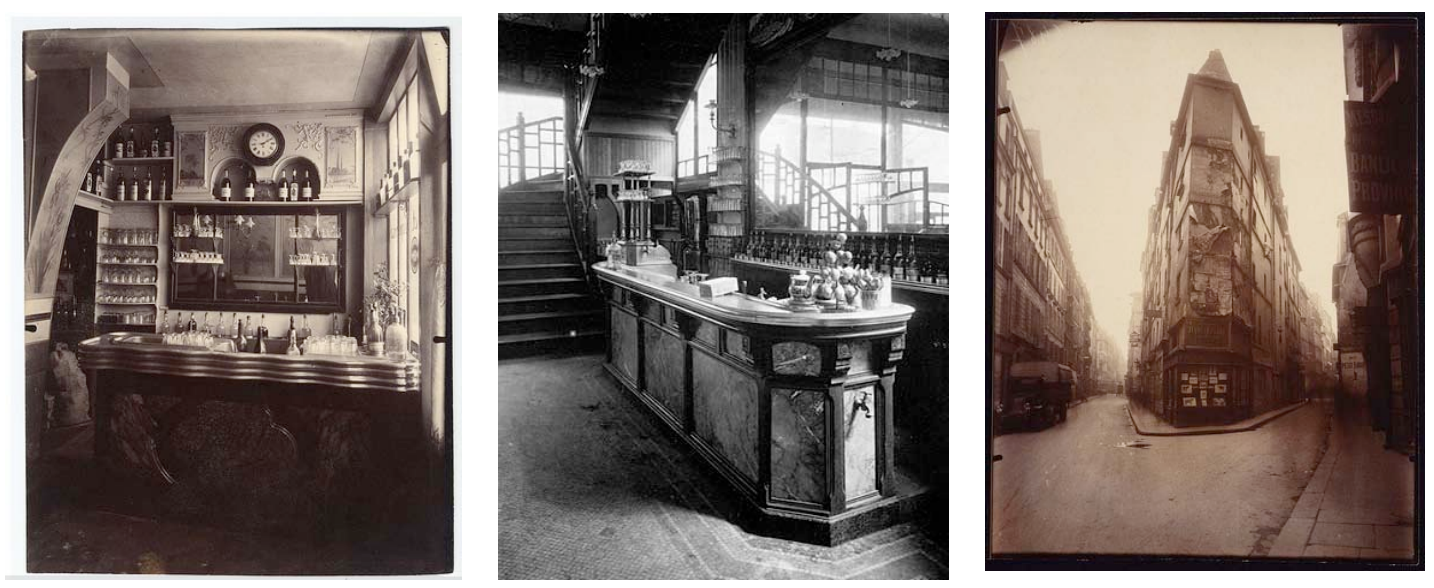

Fig. 39: Fotografias de Eugène Atget.

Quer se dizer que, se ocorriam episódios em que poderiam haver imagens fotográficas que não serviam para nada em meio à sua contemporaneidade, estas mesmas imagens já poderiam, na verdade, servir ao nada, ou seja, estariam concentradas naquelas "possibilidades supremas" que Heidegger apontara como tarefa do pensamento mais difícil: o resgate dessas

\footnotetext{
${ }^{18}$ Atget teria fotografado Paris ao longo das duas primeiras décadas do século XX, e suas imagens, após sua morte, teriam sido levadas aos EUA em1929 por Berenice Abott, assistente de Man Ray. THOMPSON, op. cit., pp. 80-83.

19 "The mere fact of transposing something seen to a photograph already implies a total invention: the recording of a unprecedented reality. Nothing has proved the rightness of surrealism more than photography". In: PHILLIPS, Cristopher. Photography in the modern era: european documents and critical writings, 1913-1940. New York: MET/Aperture, 1989, p. 34.
} 
imagens à frente de seu seu tempo comprova a potência que lhes é inerente, situando-se, assim, como "imagens de todos os tempos" e não apenas como "imagens de seu tempo".

Outro caso que vale ser apontado, ainda antes de abordar exemplos do universo digital contemporâneo, seria o trabalho de Robert Frank na década de 50, The Americans ${ }^{20}$. Hoje, bastante celebrado pelos próprios norte-americanos, este trabalho encontrou dificuldades para tal reconhecimento quando realizado na década de 1950. Frank teria lançado seu livro na França, para só depois lançá-lo em seu próprio país. Teria isso sido causado pelo incômodo gerado por suas imagens evidentemente angustiantes, que nada celebravam a potência americana no pósguerra? Na obra Photography after Frank, Philip Gefter analisa o impacto desse trabalho nos rumos da prática fotográfica, afirmando que "o imediatismo, espontaneidade, e o anarquismo de seu enquadramento mudaram as expectativas a respeito da fotografia"21.
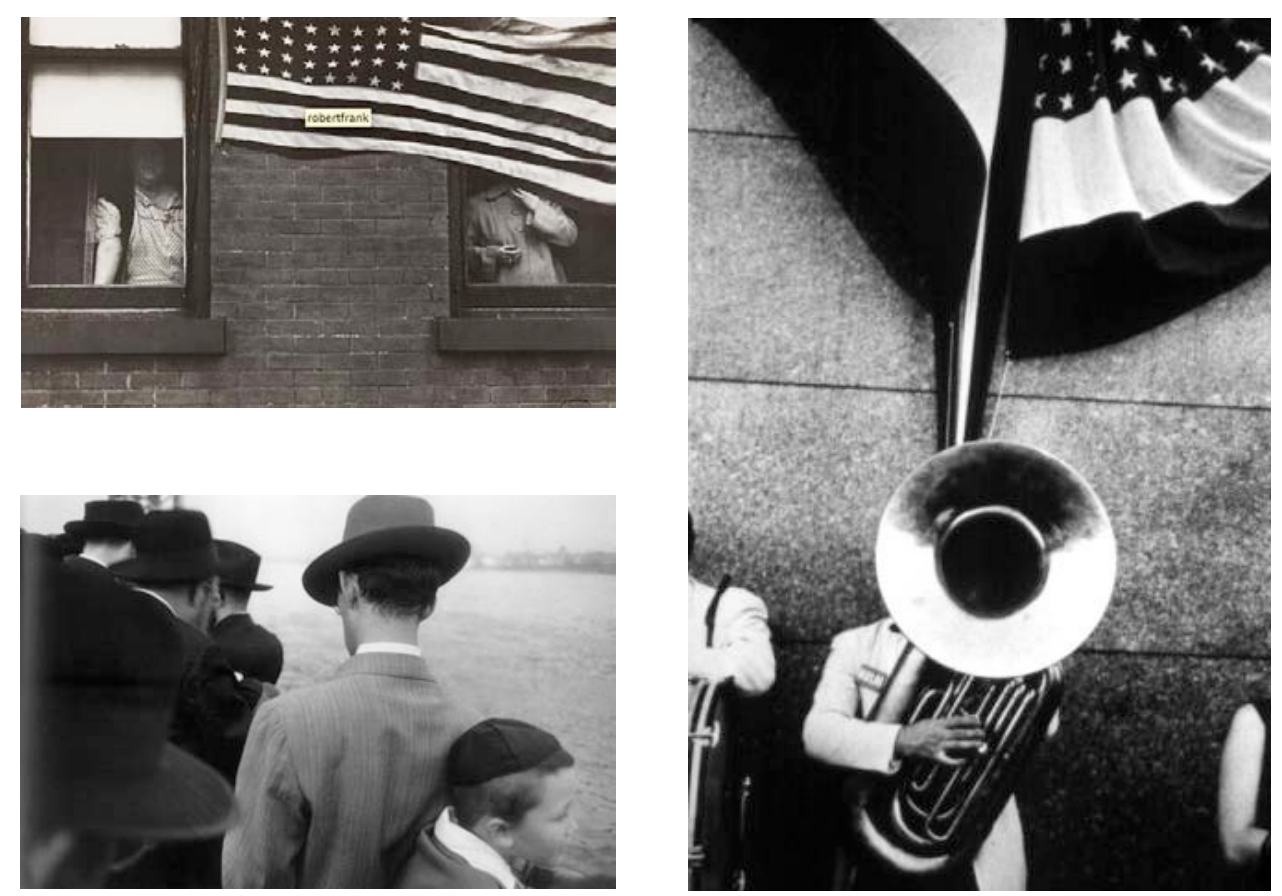

Fig. 40: fotos de Robert Frank, da série The Americans.

\footnotetext{
${ }^{20}$ FRANK, Robert. The Americans. Gottingen: Steidl, 2008.

${ }^{21}$ Tradução livre: "The immediacy, spontaneity, and compositional anarchy in his picture frame changed expectations about photography." In: GEFTER, Philip. Photography after Frank. New York: Aperture, 2009, p. 9.
} 
Tal potencial filosófico encontra espaço maior de exploração no universo digital contemporâneo. Uma das razões para assim crer é a onipresença das telas. Estas, ao mesmo tempo que permitem a troca de informações dentro da perspectiva do jogo da superficialidade, também o alimentam por meio da evidenciação de que tudo parece já ter sido registrado na forma de tecnoimagem. Ademais, os softwares de manipulação de imagens digitais, como possibilidade de incrementação da informação visual, definem a fragilidade da imagem contemporânea para lidar com uma ideia de verdade fundada na partilha entre ficção e realidade.

Exemplar é a atuação do coletivo brasileiro Cia. de Foto, que demonstra que o principal constituinte do processo criativo do grupo é a tecnologia digital aliada à fotografia. Todos os trabalhos são assinados pelo coletivo, e nunca individualmente por parte de cada um de seus integrantes, que neste momento sabe-se que são três fotógrafos e mais quatro componentes que atuam no planejamento, tratamento digital e divulgação. É fundamental ter a autoria assim reconhecida, uma vez que as imagens são produtos de discussões entre os integrantes do grupo aliadas aos procedimentos de pós-produção digital, que determinam a composição final de maneira tão efetiva quanto o momento do registro. Exercitam de forma recorrente aquilo que aqui foi anteriormente chamado de fotografia em sistema (cf. capítulo 8). Trata-se de um fluxo de trabalho facilitado e, ao mesmo tempo, incrementado de modo constante a cada nova introdução de dispositivos tecnológicos.

Como exemplo de atuação que toma proveito das possibilidades do digital, no trabalho "Políticos" (que Rubens Fernandes Jr. denomina como "Polípticos" em alusão aos dípticos, trípticos, etc. da arte contemporânea), os fotógrafos do coletivo apresentam imagens com diferentes pontos de vista de uma mesma cena envolvendo os candidatos à Prefeitura de São Paulo, em campanha para as eleições no ano de 2008. Os três fotógrafos, por meio de telefone móvel, tentavam mais ou menos sincronizar o momento em que todos disparariam suas câmeras no modo contínuo de registro (possível realizar 4, 5 ou até mais imagens por segundo). No computador, era possível determinar a imagem de cada fotógrafo que mais se aproximava do mesmo instante, pois as câmeras fotográficas, com seus relógios digitais internos, registraram 0 segundo exato da captura. 

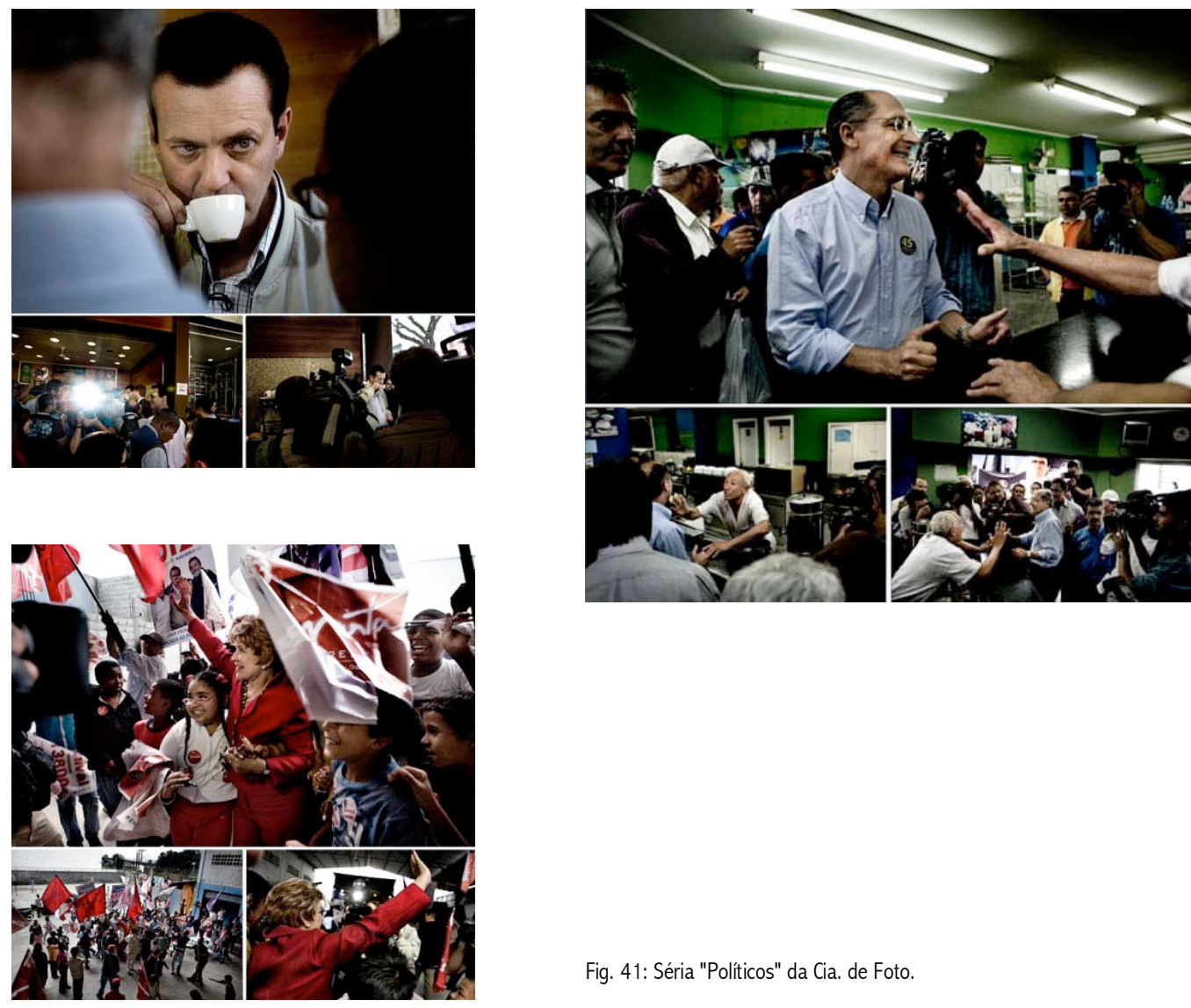

Fig. 41: Séria "Políticos" da Cia. de Foto.

Mas a fotografia como "técnica da angústia" surge num trabalho que vai além de uma linha fotojornalística que intenta também aquela nova consciência documental que pôde ser vista com Pedro Meyer: trata-se de um audiovisual intitulado "Caixa de Sapatos", montado com fotografias da intimidade familiar dos integrantes do coletivo, um "autoretrato íntimo" teriam dito. É um projeto em andamento que permite aos integrantes do coletivo experimentar a fotografia como ferramenta de autoconhecimento: reflexão sobre si mesmo. Aqui, não se trata apenas de uma ideia de subjetividade na fotografia dentro dos moldes da arte, da fotografia autoral, de se criar algo novo: a busca é em direção ao pensar pela fotografia, a imagem é mero resultado dessa postura. São imagens que servem ao nada. De forma que a objetividade da fotografia é assumida, mas não em função de um objeto a ser representado, tal como se definiu ou ainda se define muito da prática, e sim por sua adequação como técnica, agora muito mais despojada, como simples anotação de uma vivência. Algo dentro daquilo que Joan Fontcuberta teria dito 
sobre o fato de a fotografia não representar a vida, mas de ser ela a própria vivência ${ }^{22}$. Cabe também apontar que, com o "Caixa de Sapatos", o coletivo situa "fotografias de família" como principal pilar criativo, criando aquela mesma mescla entre aflição e afeição vista em / photograph to remember, de Pedro Meyer.
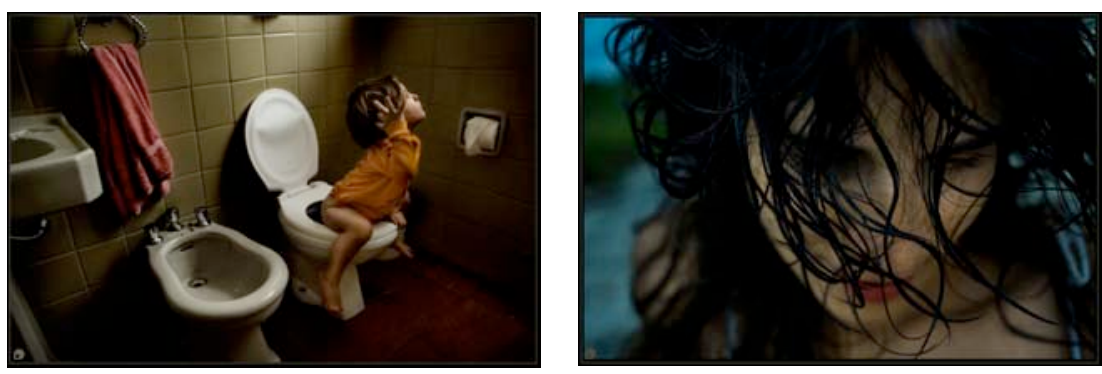

Fig. 42: Imagens do audiovisual "Caixa de Sapatos", do

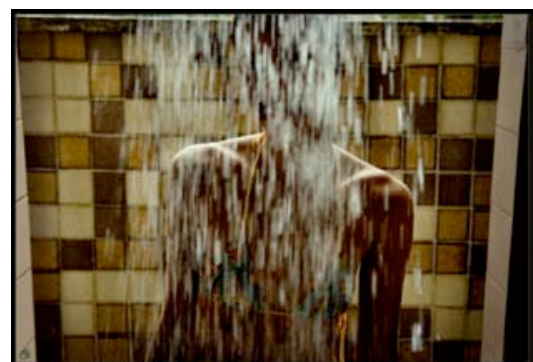

A evolução recente deste trabalho revela ainda mais esse clima de uso. As imagens para o "Caixa de Sapatos" adquirem plasticamente um caráter mais abstrato, dentro de um método por eles denominado "Hold a sec!" (algo como "espere um segundo"): trabalhando com exposições de segundos, mais longas que um instante, passam a valorizar o "mundo" que se esconde na escuridão do clique (nunca se vê o que a câmera realmente fotografa, pois seu mecanismo os torna cegos nesse momento).
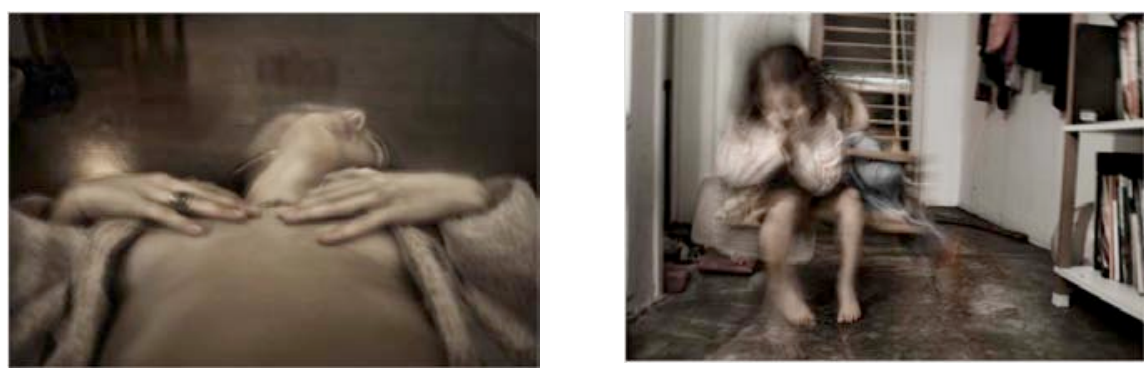

Fig. 43: Imagens da série "Hold a Sec!", por Cia. de Foto

\footnotetext{
${ }^{22}$ Corresponde a trecho de sua fala em seu relato de experiência no seminário "As invenções da fotografia contemporânea". 0 blogue do coletivo traz essa citação. (www.ciadefoto.com.br/bogue) .
} 
Breno Rotatori (São Bernardo do Campo, 1987), outra atuação que vale apontar, parece operar com a fotografia dentro dessa mesma perspectiva ontológica. No blogue do fotógrafo vêse espaço para uma linha de trabalho que denomina como "bloco de notas", onde esclarece:

0 bloco de notas é uma busca do "não" fotografável, extrair do real uma subjetividade que dê conta de discutir o campo da metafísica, discutir o íntimo do ser humano - sua fragilidade, seus medos, suas sensações - da qual também faço parte. Partindo deste princípio, monto um bloco de notas com imagens, fotografo meu cotidiano desconstruindo-o. Criando do real uma fantasia, que leve a discussão para além do tema23.
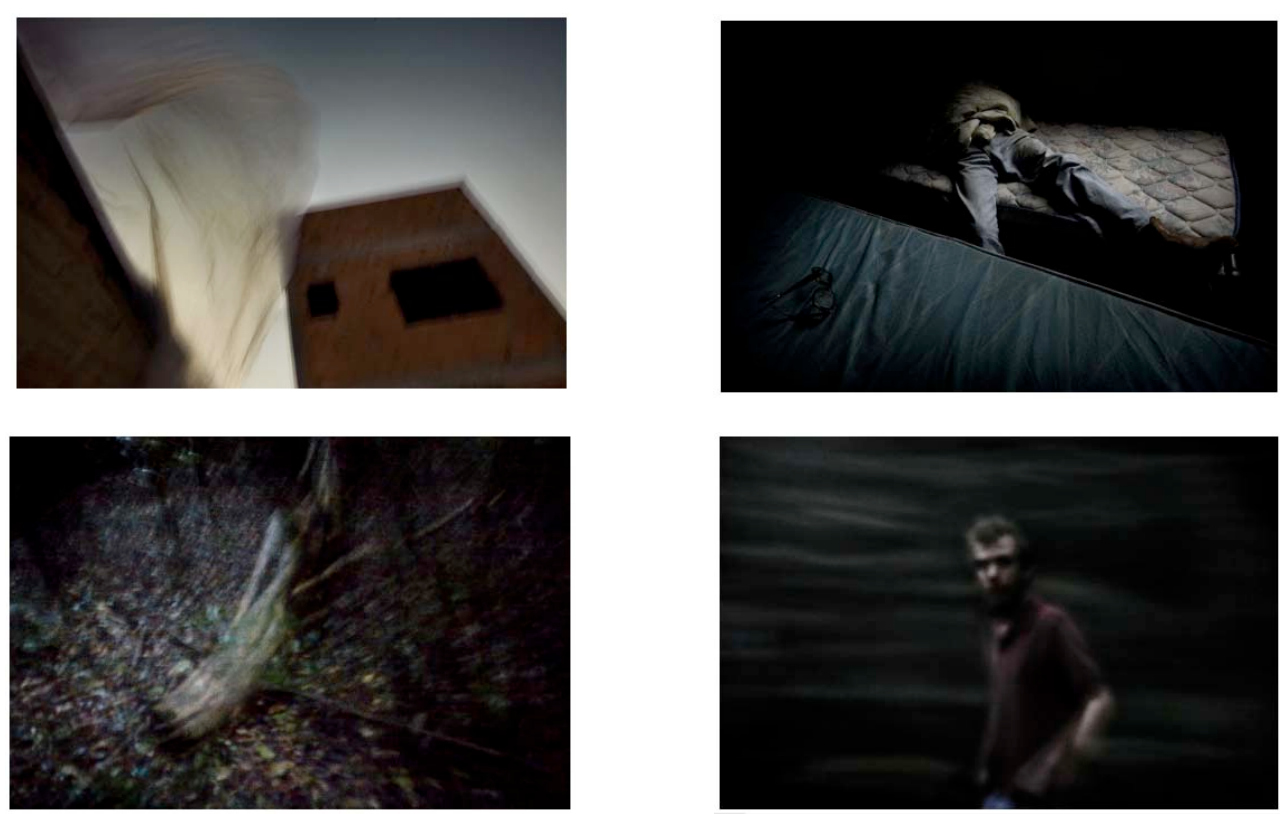

Fig. 44: Imagens de Breno Rotatori da série "Bloco de notas".

Rotatori, premiado em 2009 como revelação num reconhecido concurso da fotografia brasileira $^{24}$, o qual teve como tema a "fotografia e o tempo", parece assumir de forma mais consciente este caráter de autoinvestigação da fotografia em sua configuração digital. As imagens premiadas, intituladas "Man é lud", trazem dípticos em que o autor contrapõe o mesmo instante sob dois pontos de vista de câmeras que se apontam; e o que torna este trabalho emblemático para esta tese, além do fato de ser evidência de "imagens que olham", é o fato de as duas

\footnotetext{
${ }^{23}$ Disponível em <http://brenorotatori.wordpress.com>. Acesso em novembro de 2009.

${ }^{24}$ Prêmio Porto Seguro de Fotografia.
} 
imagens resultantes terem sido produzidas, uma no formato digital, e a outra no formato tradicional com película.
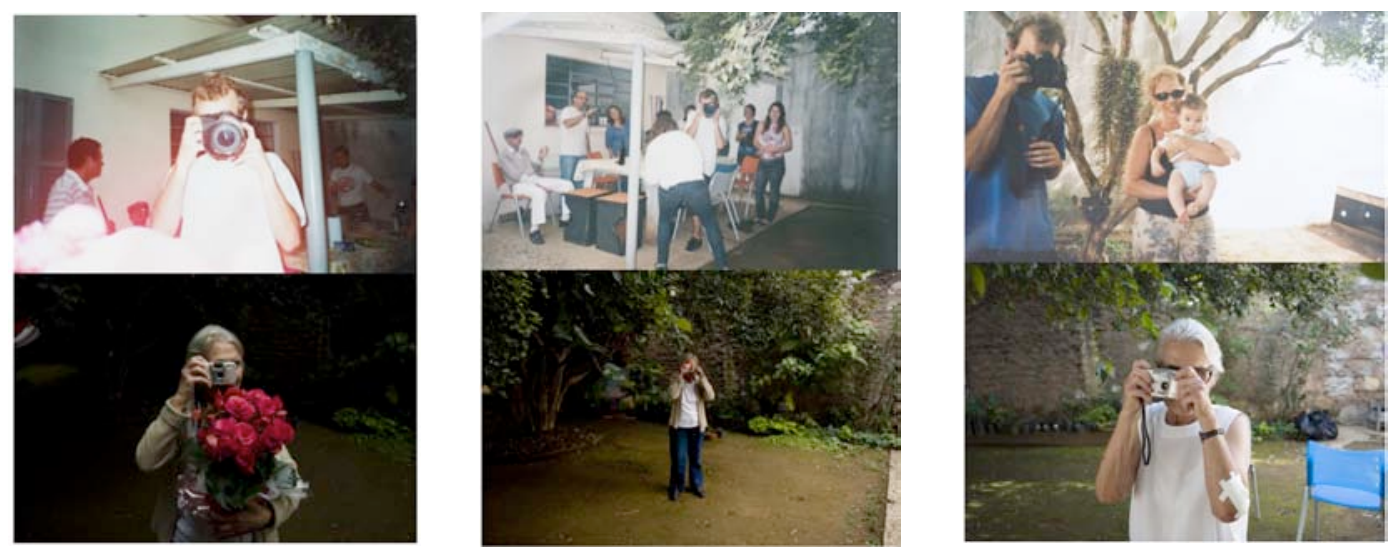

Fig. 45: imagens da série "Man é lud".

Cia de Foto e Breno Rotatori tornam-se exemplos de um pragmatismo fotográfico que deixa de se resumir a objetos representados, ou mesmo ao "olhar do fotógrafo" sobre algo, a uma "visão de mundo", pois o mundo representado ali em nada se assemelha ao mundo como objeto, mas como ambiente para promover, como Rotatori mesmo assume, a discussão sobre 0 seu íntimo, suas fragilidades e seus medos. 0 pragmatismo aqui em jogo objetiva uma experiência que não parece importar-se com a precisão, pelo contrário, é pela imprecisão que tais imagens ganham a sua evidência, vale dizer, pela evidenciação do nada.

Nestes trabalhos, a fotografia assume caráter instrumental quase descartável, digno de um lápis que se usa para anotar um lembrete, esboçar um desenho ou uma ideia qualquer. Nada a ver com o lápis de Henry Fox Talbot em The pencil of Nature (1846), que exaltava a fotografia como reprodução técnica, provocando a possibilidade de uma relação aflitiva com a sua tecnologia, exigindo conhecimento e domínio para a busca de uma precisão (straight photography); mas talvez um pouco mais próximo de George Eastman (fundador da Kodak), que buscava desenvolver uma tecnologia fotográfica tão fácil de usar quanto um lápis ${ }^{25}$, e que estabeleceu os alicerces da prática cultural da fotografia dentro de uma perspectiva mais afetiva de uso da técnica.

Tal forma de uso sempre foi possível e praticada, mas ao longo de quase toda a história da fotografia, quando esta se ocupava com a história do mundo, essas propostas de imagens

${ }^{25}$ Informação colhida no web site da companhia. In: http://www.kodak.com.br. Acesso em outubro de 2009. 
"para nada serviam", e só recentemente é que se passou a perceber a sua importância: que sirvam de exemplos os anônimos resgatados por Robert Flynn Johnson, e o "impacto tardio" das imagens de Eugène Atget e Robert Frank. Imagens angustiantes que ganham, na superficialidade, a ambiência necessária gerada pelo tédio das mútliplas imagens em múltiplas telas, em que homens, sujeitos ou artistas, agora reduzidos a jogadores, buscam encontrar sua natureza mais essencial.

Couchot teria dito que o numérico "intima o sujeito a se redefinir" ${ }^{26}$. A tecnoimagem, bem como todas as suas consequências, demonstram certa presunção moderna em tal assertiva: 0 que o universo digital parece mesmo demonstrar é que esse sujeito está longe de, pelo menos, conseguir se definir.

${ }^{26}$ COUCHOT, op. cit. p. 158. 
Falar sobre fotografia quase sempre significa o mesmo que falar sobre a imagem fotográfica. E aqui, ao final, não poderia ter sido diferente. 0 fim de qualquer discussão a respeito da fotografia é o habitus perceptivo que foi inaugurado com seu novo potencial figurativo. A tecnologia como ponto de apoio foi a tentativa de buscar uma centelha de reflexão que não dependesse inicialmente das questões que envolvem a semântica, sobretudo pela crença de que aquele "terror" que Barthes atribui à presença da "cadeia flutuante de significados" é situação incontornável. Enfim, tomar a tecnologia como porta de acesso é tentar compreender a fotografia, e não o significado de fotografias. Cabe ressaltar: aqui, neste estudo, as fotografias nada significam, isto quando se entende a verbalização como principal pilar de um processo de significação.

Mas deve-se dizer que tal associação com o nada não fica só perceptível quando se depara com imagens despidas de objetivos, despojadas, imagens "de passagem", como que capturadas de relance, e que foram aqui exemplificadas no capítulo final. Sim, estas imagens desafiam qualquer processo de verbalização, até porque dificultam o reconhecimento imediato das formas ali representadas. Mas o nada pode ser percebido também nas imagens objetivas que 
trazem ainda com mais evidência a informação, pois convidam à inutilidade da palavra. Não se trata aqui de supor que as tecnoimagens não tenham presença: elas vendem carros e eletrodomésticos, e movem multidões para salas de cinema, galerias e museus; no entanto, caberia indagar: são tão atuantes e decisivas assim devido ao seu potencial de verbalização, isto é, significação, ou justamente pelo contrário?

Essa derradeira associação da fotografia com o nada surge como tentativa de definir marco-zero para a exploração do seu potencial, mas sem qualquer comparação com a palavra, e isso poderia até comprometer o uso do termo "linguagem", se este termo for entendido também como consequência da palavra. Apontar esse nada é tentativa de silenciar o universo do logos, seja esse logos considerado como o "verbo", a "palavra", a "razão", o "discurso" ou a "lógica": a gramática e a lógica, lembre-se a partir de Heidegger, tornaram-se os "grilhões" da linguagem, e caberá à tecnoimagem fazer notar estes grilhões, e exatamente isto é o que parece querer apontar Flusser. Está aí o potencial filosófico das tecnoimagens.

$\mathrm{Na}$ esteira do encontro com a linguagem num estado mais originário, vem o encontro com as motivações e os desejos que envolvem o fazer, e agora sem a necessidade do saber. A "pretidão da caixa pode ser ignorada", e o homem foi libertado para a superfície do processo, diz Flusser. Assim deve ser entendida a ideia da banalização da tecnologia: o silenciamento do logos na técnica e, por isso, concentração na práxis, ou melhor, mobilização a partir de reais necessidades que se dão numa relação menos aflitiva com a técnica, o que parece permitir determinar o papel efetivo da imagem de maneira mais consciente.

Quando inventada e a caminho de ser enraizada socialmente, coube à fotografia copiar 0 mundo. Por quase todo o século XIX e por quase todo o século passado, tudo foi registrado por meio de sua tecnologia e seus desmembramentos (cinema, vídeo): tal foi a tarefa das tecnoimagens. É um pouco esta constatação que permite tanto a Lissovsky afirmar que a fotografia parece ter encerrado seu ciclo de criação, quanto a Lemagny afirmar a história da fotografia como sendo o mesmo que a história-através-da-fotografia. Esse esgotamento coincide com a sua entrada no digital.

A tela, dada a sua onipresença e seu caráter tecnicamente homogeneizador, assim como o crescente acesso a "todas as imagens do mundo" que permite, coloca a fotografia somente como uma extensão de sua ubiquidade, não mais como ponto de partida, mas somente como mais uma pequena área anexada. "Googlegrams", de Fontcuberta, é exemplar neste sentido. 
Qualquer imagem que se declare como "nova" deve ser questionada, assim como a idéia de uma "boa imagem" perde cada vez mais o sentido, pois nesse amplo circuito de circulação não parece existir espaço para imagens que causem impacto, surpresa ou incômodo (basta comparar a repercussão banal que circundam as imagens espaciais contemporâneas com a repercussão que as imagens da Lua obtiveram: esgota-se o mundo em imagens e os outros mundos já surgem esgotados). A possibilidade do "novo" surge no jogo e não mais por meio de novas imagens, pois quando a fotografia entra no digital, ou o digital captura a fotografia, o tédio já está instalado.

Decorre daí que o fotografável -as cenas já prontas que Flusser apontara-, torna-se inevitável para profissionais, amadores, artistas, funcionários ou fotógrafos experimentais, restando a todos a única possibilidade de jogar com todo esse cenário. Pois é isso que a tecnoimagem desabriga e desafia: aquele homem que se esconde por trás dessas categorias. $\mathrm{Ou}$ melhor, a criança, já que se trata de um mundo em que aparelhos são brinquedos. Além do que, ainda parece que se engatinha em relação ao que estas tecnoimagens representam. Pois uma coisa é produzir imagens sérias (straight photography), outra coisa é levar à sério as imagens: 0 mais talentoso fotógrafo ainda fica frustado com o sanduíche que é servido pelo garçon, que nada tem a ver com a imagem do cardápio que traz a mensagem fotografia meramente ilustrativa, mensagem essa que, visto a sua obrigatoriedade, denuncia a necessidade do amadurecimento.

Enfim, considera-se a invenção da fotografia o ano de 1839, mas a sua descoberta mesmo pode ter ocorrido só recentemente. A zero-dimensionalidade do universo dos aparelhos, agora mais do que presente pelos zeros e uns, contribui inevitavelmente para a equalização de todo tipo de informação que se refere ao conhecimento, criando assim a ambiência para aquilo que o hibridismo inerente à fotografia teria reinaugurado: a conjunção da arte com a ciência. Quando se utilizam os termos de Flusser, é possível afirmar que a pós-industrialidade da fotografia não foi percebida por não existir -tal como agora ocorre-, um contexto pós-industrial.

No catálogo de "A última foto", emblemático trabalho para esta tese, justamente por ter discutido as consequências do processo de transição tecnológica da fotografia, Rosângela Rennó decreta: "Adeus fotografia". Talvez seja o caso de proclamar justamente o contrário.

Seja bem-vinda, fotografia. 


\section{REFERÊNCIAS BIBLIOGRÁFICAS}

ABREU, Leandro Pimentel. Do pit ao eu-repórter: a busca do caráter noticioso na fotografia. Trabalho apresentado no Núcleo de Pesquisa Fotografia: Cultura e Comunicação. XXXII Congresso Brasileiro de Ciências da Comunicação, 2009.

ADAMS, Ansel. An autobiography. New York: Little Brown and Company, 1986.

. Making a photography. London: Studio, 1935.

AMAR, Pierre-Jean. História da Fotografia. Lisboa: Edições 70, 2007.

ARRUDA, Francimar Duarte. A questão do imaginário: a contribuição de Sartre. In: Em aberto, ano 14, n. 61. Brasília: Ministério da Educação, 1994.

AUMONT, Jacques. A imagem. Campinas: Papirus, 1993.

BAITELLO, NORVAL . Vilém Flusser e a Terceira Catástrofe do Homem ou as Dores do Espaço, a Fotografia e o Vento. FlusserStudies.net, v. 3, p. 7, 2006.

As quatro devorações. Iconofagia e Antropofagia na Comunicação e na Cultura. Disponível em: www.compos.org.br/data/biblioteca_121.pdf. Acesso em agosto de 2008.

BARTHES, Roland. O óbvio e o obtuso. Rio de Janeiro: Nova Fronteira, 1990.

. Aula. São Paulo: Cultrix, 1988.

. A câmara clara. Rio de Janeiro: Nova Fronteira, 1984.

BATCHEN, Geoffrey (org.). Photography degree zero: reflections on Roland Barthes's Camera Lucida. Cambridge: MIT Press, 2009.

BAUDRILLARD, Jean. Simulacros e Simulação. Lisboa: Relógio D Água, 1991.

BAURET, Gabriel. Fotografia: história, estilos, tendências, aplicações. Lisboa: Edições 70, 2006.

BELLOUR, Raymond. Entre-imagens. São Paulo: Papirus,1997.

BENJAMIN, Walter. Pequena história da fotografia. In: Magia e técnica, arte e politica: ensaios sobre literatura e história da cultura. São Paulo: Brasiliense, 1996.

- A obra de arte na era de sua reprodutibilidade técnica. In: Magia e técnica, arte e política: ensaios sobre literatura e história da cultura. São Paulo: Brasiliense, 1996. 
BERGSON, Henri. Introdução à metafísica. In: Cartas, conferências e outros escritos. São Paulo: Nova Cultural, 2005.

A intuição filosófica. In: Cartas, conferências e outros escritos. São Paulo: Nova

Cultural, 2005.

BERNARDO, Gustavo; FINGER, Anke; GULDIN, Rainer. Vilém Flusser: uma introdução. São Paulo: Annablume, 2008.

BOURDIEU, Pierre. Un arte medio. Barcelona: Gustavo Gili, 2003.

BRAGA, Robson Aurélio Adelino. Roland Barthes e a escritura: um olhar poético sobre o signo fotográfico. Disponivel em: www.studium.iar.unicamp.br/19/barthes/2.html . Acesso em setembro de 2008.

CARTIER-BRESSON. El instante decisivo. In: Fotografiar del natural. Barcelona: Gustavo Gili, 2003, pp 1135.

COLI, Jorge. Rascunhos e harmonias. São Paulo: Folha de S. Paulo, Caderno Mais, p. 2, ed. 6 de agosto de 2006.

COSTA, Helouise; SILVA, Renato Rodrigues da. A fotografia moderna no Brasil. São Paulo: Cosac Naify, 2004.

COUCHOT, Edmond. A tecnologia na arte: da fotografia à realidade virtual. Porto Alegre: Ed. Da UFRGS, 2003.

DEBORD, Guy. A sociedade do espetáculo. Rio de Janeiro: Contraponto, 1997.

DEBRAY, Regis. Vida e morte da imagem. São Paulo: Brasiliense, 1994.

DELLEUZE, Gilles. Conversaç̃̃es. Rio de Janeiro: Editora 34, 1992.

DOBRANSZKY, Diana de Abreu. A fotografia entre a arte e a máquina. Disponível em: www.studium.iar.unicamp.br/21. Acesso em 15/8/2006.

DOMINGUES, Diana (org.). A arte no século XXI: a humanização das tecnologias. São Paulo: Fundação Editora da UNESP, 1997.

DUBOIS, Philippe. As tensões na fotografia: entre a ficção e o real. Conferência realizada no Departamento de Jornalismo da ECA/USP. São Paulo, 1/9/09.

Cinema, video, Godard. São Paulo: Cosac Naify, 2004.

O ato fotográfico e outros ensaios. Campinas: Papirus, 1994.

DUNLEY, Gláucia. A festa tecnológica: o trágico e a crítica da cultura informacional. São Paulo: Editora Escuta/Rio de Janeiro: Fiocruz, 2005. 
DURAN, Regis. El tiempo de la imagen: ensaio sobre las condiciones de una historia de las formas fotográficas. Salamanca: Centro de Fotografia de la Universidad de Salamanca, 1998.

ECO, Humberto. Tratado geral da semiótica. São Paulo: Perspectiva, 2007.

ENTLER, Ronaldo. Fotografia contemporânea: entre olhares diretos e pensamentos obtusos. Trabalho apresentado no GP Fotografia, IX Encontro dos Grupos/Núcleos de Pesquisas em Comunicação, evento componente do XXXII Congresso Brasileiro de Ciências da Comunicação, 2009.

FABRIS, Annateresa (org.). Fotografia: usos e funções no século XIX. São Paulo, Edusp, 2008.

. Redefinindo o Conceito de Imagem. Revista Brasileira de História. São Paulo, v. 18, n. 35, 1998. Disponível em: http://www.scielo.br/. Acesso em: 19 Mar 2007.

FERNANDES Jr., Rubens. Entrevista coletivos Cia. De Foto e Pandora. Conferência realizada no Paraty em Foco em 27/9/2009. Disponivel em: www.ciadefoto.com.br/blogue. Acesso em outubro de 2009.

FLUSSER, Vilém. Filosofia da caixa preta. Rio de Janeiro: Relume Dumará, 2002.

Da religiosidade: a literatura e o senso de realidade. São Paulo: Escrituras, 2002.

. Língua e realidade. São Paulo: Annablume, 2007.

. Bodenlos: uma autobiografia filosófica. São Paulo: Annablume, 2007.

O universo das imagens técnicas: elogio da superficialidade. São Paulo: Annablume,

2008.

O mundo codificado. São Paulo: Cosac Naify, 2007.

. Instrumento do fotógrafo ou fotógrafo do instrumento. Revista IRIS, São Paulo,

agosto de 1982.

FOLHA DE S. PAULO. Coleção Folha Grandes Fotógrafos. São Paulo: Editorial Sol90, 2009.

FONTCUBERTA, Joan. Deconstructing Osama: the truth about the case of Manbaa Mokfhi. Barcelona: Actar, 2007.

. Miracles \& Co. Fotografias. Disponível em: http://www.zabriskiegallery.com. Acesso em agosto de 2009.

Fotografia: crisis de historia. Barcelona: Actar, 2003.

Contranatura. Barcelona: Actar: 2001

Twilight zones. Barcelona: Actar, 2000.

. El beso de Judas: fotografia y verdad. Barcelona: Gustavo Gili, 1997.

Herbarium. Gottingen: European Photography, 1985 (com prefácio de Vilém Flusser). 
FRANK, Robert. The Americans. Gottingen: Steidl, 2008.

FREITAS, Gabriela. A constituição dos gêneros fotográficos. Disponível em: http://www. fotoclubef508.com. Acesso em julho de 2009.

GEFTER, Philip. Photography after Frank. New York: Aperture, 2009.

GERNSHEIM, Helmut. The Rise of Photography: 1850-1880 - The age of Collodion. New York : Thames and Hudson, 1988.

GUSTAVSON, Todd. Camera: a history of photography from daguerreotype to digital. New York: Sterling, 2009.

HARVEY, David. Condição pós-moderna. São Paulo: Loyola, 1993.

HEDGECOE, John. O Manual do fotógrafo. Porto: Porto,1982.

HEIDEGGER, Martin. Seminários de Zollikon. Petrópolis: Vozes, 2009.

.A época das imagens de mundo. Disponível em http://ateus.net/artigos/filosofia/

a_epoca_das_imagens_de_mundo.php. Acesso em novembro de 2009.

.Introdução à filosofia. São Paulo: Martins Fontes, 2008, p. 20.

.A questão da técnica. In: Scientiae Studia, volume 5, n. 3. São Paulo: Faculdade de Filosofia, Letras e Ciências Humanas da Universidade de São Paulo, [1953] 2007, pp 375-398.

Conferências e escritos filosóficos. São Paulo: Abril Cultural, 1979.

. A origem da obra de arte. Lisboa: Edições 70, 2007.

HIRSCH, Robert. Light and lens: photography in the digital age. Oxford: Elsevier, 2008.

JOHNSON, Robert Flynn. Anonymous: enigmatic images from aunknown photographers. New York: Thames \& Hudson, 2004.

KOETZLE, Hans-Michael. Photo Icons - the story behind the pictures -volume 1. London: Taschen, 2002.

KOSSOY, B. Hercules Florence: a descoberta isolada da fotografia no Brasil. São Paulo: Edusp, 2006.

Fotografia \& história. São Paulo: Ateliê Editorial, 2001.

LEMOS, André. Ciber-Socialidade - Tecnologia e Vida Social na Cultura Contemporânea. In: Ione Bentz; Albino Rubim; José Milton Pinto. (orgs.). Práticas Discursivas na Cultura Contemporânea. São Leopoldo: Unisinos, 1999, pp. 9-22.

LICHTENSTEIN, Jacqueline (org.). A pintura: da imitação à expressão. São Paulo: Editora 24, 2004. 
LIER, Henri Van. Philosophy of photography. Leuven: Lieven Gevaert Research Center, 2007.

LISSOVSKY, Maurício. 0 tempo e a originalidade da fotografia moderna. In: DOCTORS, M. (org.). Tempo dos tempos. São Paulo: Jorge Zahar, 2003.

LUZ, R. Novas imagens: efeitos e modelos. In: PARENTE, André. Imagem máquina: a era das tecnologias do virtual. Rio de Janeiro: Editora 34, 1993, p. 53.

MACHADO, Arlindo. Arte e mídia. Rio de Janeiro: Jorge Zahar, 2007. . Pré-cinemas e pós-cinemas. Campinas: Papirus, 2002.

[www.studium.iar.unicamp.br/2]. Acessado em 17/08/2003.

.Repensando Flusser e as imagens técnicas. Disponivel em: www.fotoplus.com/flusser/vftxt/vfmag/ vfmag002.htm. acesso em 21/03/2007.

A ilusão especular. São Paulo: Brasiliense, 1984.

MAMMI, Lorenzo; SCHWARCZ, Lilia Moritz (orgs.). 8 X Fotografia. São Paulo: Companhia das Letras, 2008.

MARIEN, Mary Warner. Photography: a cultural history. New York: Harry N. Abrams, 2002.

MARKOFF, John. Chip se aproxima de seu limite. Caderno The New York times. Folha de S. Paulo, 14/09/09, p. 5.

MEYER, Pedro. Truths \& fictions: from documentary to digital photography. New York: Aperture, 1995.

. I photograph to remember. Fotografias digitais. Disponível em: www.zonezero.com. Acesso em julho de 2007.

MIĖGE, Bernard. A sociedade tecida pela comunicação. São Paulo: Paulus, 2009.

MITCHELL, William J. The reconfigured eye: visual truth in the post-photography era. Cambridge: MIT Press, 1992.

MOREIRA LEITE, Miriam. Retratos de família. São Paulo: Edusp, 1993.

NEWHALL, Beaumont. Photography: a short critical history. New York: Moma, 1938.

OLIVEIRA, Elaine Harada T. Introdução à lógica de programação. Disponível em: http://www.dcc.ufam.edu.br. Acesso em dezembro de 2009.

PASI, Alessandro. Leica: witness to a century. New Yorrk: Norton \& Company, 2003.

PAVÃO, Luis. Conservação de colecções de fotografia. Lisboa: Dinalivro, 1997.

PEIRCE, Charles Sanders. Semiótica. São Paulo: Perspectiva, 2005. 
PHILLIPS, Cristopher. Photography in the modern era: European documents and critical writings, 19131940. New York: MET/Aperture, 1989.

PINTO, Álvaro Vieira. 0 conceito de tecnologia. Rio de Janeiro: Contraponto, 2005. 2v.

RENNÓ, Rosângela. Web site da artista. Disponível em www.rosangelarenno.com. Acesso em agosto de 2008.

Bate-papo (chat) com a artista ocorrido em 17/5/2007. Disponível em:

http:/tc.batepapo.uol.com.br/convidados/arquivo/arte/ult1739u111.jhtm. Acesso em junho de 2007.

. A última foto. São Paulo: Galeria Vermelho, 2006.

. Rosângela Rennó. São Paulo: Edusp, 1997.

REXER, Lyle. The edge of vision: the rise of abstraction in photography. New York: Aperture, 2009.

RITCHIN, Fred. After Photography. New York: W.W. Norton \& Company, 2009.

ROSSET, C. O Real e seu duplo. Rio de Janeiro: José Olympio, 2008.

ROSENBLUM, Naomi. A world history of photography. New York: Abbeville Press, 2007.

RUDIGER, Francisco. Introdução às teorias da cibercultura - perspectivas do pensamento tecnológico contemporâneo. Porto Alegre: Ed. Sulinas, 2003.

RUSSEL, Bertrand. História da filosofia ocidental. São Paulo: Companhia Editora Nacional, 1969.

SAFRANSKY, Rudiger. Heidegger: um mestre da Alemanha entre o bem e o mal. São Paulo: Geração Editorial, 2005.

SARTRE, Jean-Paul. A imaginação. São Paulo: Abril, 1978.

. L'imaginaire. Paris: Gallimard, 1940.

SCHAEFFER, Jean-Marie. A imagem precária. São Paulo: Papirus,1996.

SCHARF, Aaron. Arte y fotografia. Madri: Alianza Editorial, 1994.

SILVA, Franklin Leopoldo. Martin Heidegger e a técnica. Disponível em: www.scientiaestudia.org.br/revista/PDF/05_03_04.pdf. Acesso em 4/7/08.

SILVA, Juremir Machado da. De Heidegger a Baudrillard: os paradoxos da técnica. Disponível em www.comunica.unisinos.br/tics/textos/2000/2000-jms.pdf. Acesso em 04/07/08.

SILVA, Tomaz Tadeu da (Org.) . Antropologia do ciborgue: as vertigens do pós-humano. Belo Horizonte: Autêntica, 2000.

- Pedagogia dos monstros: os prazeres e os perigos da confusão de fronteiras. Belo Horizonte: Autêntica, 2000. 
SILVA, Vanessa Corrêa da. Um retrato humano da guerra: fotografias de Robert Capa. Trabalho de conclusão de curso apresentado ao Departamento de Jornalismo da Escola de Comunicação e Artes da Universidade de São Paulo. São Paulo: 2009.

SODRÉ, Muniz. Entrevista. Revista Pesquisa Fapesp - Especial Revolução Genômica. São Paulo: FAPESP, setembro de 2008, pp.77-82.

SONTAG, Susan. Diante da dor dos outros. São Paulo: Companhia das Letras, 2007.

. Sobre Fotografia. São Paulo: Companhia das Letras, 2004.

SOUGEZ, Marie-Loup. História da fotografia. Lisboa: Dinalivro, 2001.

SOUZA E SILVA, Wagner. Entre fotografias cientificas e a ciência da fotografia. In: Revista do Museu de Arqueologia e Etnologia, n. 17. São Paulo: MAE/USP, 2007, pp 435-444.

Fotos em cena, cenas em foto: a presença da fotografia estática na tela audiovisual. 2004.

Dissertação (Mestrado) - Escola de Comunicações e Artes, Universidade de São Paulo, São Paulo.

THOMPSON, Nicola (org.). Tecnicas de los grandes fotografos. Madrid: Hermman Blue Ediciones, 1981.

TACCA, Fernando de. Olho mágico. Disponível em http://www.scielo.br/pdf/pp/v19n1/.pdf. Acesso em setembro de 2009.

Fotografia e cinema: intertextualidades. Trabalho apresentado no Núcleo de Pesquisa Fotografia: Cultura e Comunicação. XXX Congresso Brasileiro de Ciências da Comunicação, 2007.

TAUSK, Petr. Historia de la fotografia en el siglo XX. Barcelona: Gustavo Gili, 1978.

TRIG0, Thales. Equipamento fotográfico: teoria e prática. São Paulo: Senac, 2005.

VATTIMO, Gianni. A sociedade transparente. Lisboa: Relógio d’Água, 1992.

ZAMBONI, Sílvio. A pesquisa em arte: um paralelo entre arte e ciência. Campinas: Autores Associados, 2006 
http://brenorotatori.wordpress.com

http://www.adobe.com

http://www.archive.worldpressphoto.org/years

http://www.ciadefoto.com.br/blog

http://www.graflex.org/speed-graphic

http://www.kodak.com

http://www.photographie.essonne.fr

http://tc.batepapo.uol.com.br/convidados/arquivo/arte/ult1739u111.jhtm

http://www.youtube.com/watch?v=zbRyjk2anVM.

http://www.zonezero.com 
Em maio de 2008 tentei contato com Joan Fontcuberta por e-mail, e ele prontamente respondeu. Tentamos realizar uma entrevista pela internet, mas estando totalmente ocupado com sua atribulada agenda, Fontcuberta não deu continuidade à conversa. Para minha surpresa, ele próprio enviou uma mensagem antes de sua vinda recente a São Paulo, disponibilizando-se para um encontro aqui. A entrevista foi realizada no dia 13 de outubro, nas dependências do Itaú Cultural de São Paulo, um dia antes da abertura da exposição "A invenção de um mundo", com imagens do acervo da Maison Européenne de la Photographie. A conversa, inicialmente prevista para as 15 horas, foi remarcada para as 17 horas, sendo realizada às 18 horas. Em função dos atrasos acumulados durante o dia (Fontcuberta realizara um workshop naquele dia, e quando conversamos, acabava de sair de um reunião com o setor educativo do instituto), a conversa teve de ser muito rápida e durou 15 minutos. Mas apesar de deixar algumas indefinições que mereceriam discussão mais aprofundada, a entrevista foi suficiente para obter informações significativas sobre o trabalho do artista, e embora tenhamos falado pouco sobre sua relação com Vilém Flusser, foi possível colher também um breve, mas decisivo comentário sobre a fotografia na era digital. Devo agradecer a Marie Hippenmeyer, produtora, e a Eder Chiodetto, curador da mostra, pela atenção e oportunidade que me deram quando se disponibilizaram a efetivar tal encontro. 
Recentemente o Sr. realizou uma restrospectiva em Barcelona. Percebo que em seus primeiros trabalhos o $\mathrm{Sr}$. demonstrava uma preocupação mais evidente em questionar o caráter documental da fotografia por meio da ciência. Nos últimos trabalhos, o Sr. tem demonstrado mais interesse no fotojornalismo... o que me interessa questionar é todo princípio de autoridade e autentificador do valor testemunhal da fotografia. A ciência é uma das plataformas de poder, mas existem outras: a televisão, os meios de comunicação, a política, etc., e o que me interessa é criticar todos estes vetores. Mas nunca abandonei meu interesse na ciência: tenho desenvolvido projetos em paleontologia, interessa-me também a arqueologia e outras formas do positivismo científico. Foi por questões de agenda e estratégia que desenvolvi meus últimos projetos em fotojornalismo, mas considero este envolvimento apenas circunstancial. Meu interesse se concentra em continuar indagando os domínios em que a fotografia seja encarada de forma positivista.

0 seu envolvimento inicial com a fotografia já foi direcionado para essas questões?

Minha formação é em Artes Visuais e Ciências da Comunicação, que na Espanha chamamos de Ciência da Informação. Trabalhei em publicidade e fotojornalismo. Essa experiência profissional me familiarizou com a questão do simulacro, a questão da verdade e da mentira. Este tem sido o tema pelo qual me interessa desenvolver o núcleo conceitual de minhas indagações. Se elegi a fotografia como meio principal para isso é por que ela representa um dispositivo autentificador, mas não há nada na natureza da fotografia que justifique a sua autoridade: deve-se desconstruir, desmontar, contradizer a autoridade certificadora do meio fotográfico.

E hoje com o digital, o Sr. ainda acha que existe espaço para esse tipo de discussão? A fotografia ainda é encarada como sinônimo de verdade?

A fotografia perdeu peso como agente autoritário. Mas na medida em que os espectadores estão mais críticos em relação às imagens, os especialistas em manipulação digital tornam seu trabalho cada vez mais refinado, portanto sempre há uma brecha entre a mensagem e o público. Nesse sentido, a fotografia faz uso de mecanismos que seguem fortalecendo sua capacidade interpretativa. 


\section{O Sr. conheceu Vilém Flusser pessoalmente?}

Sim. Ele escreveu a introdução de meu primeiro livro Herbarium, em 1984, e nessa época ele morava no Sul da França, e por isso nos encontramos outras vezes.

É muito emocionante ver a sua dedicação a Vilém Flusser em El Beso de Judas (1998). Ele ainda está presente em seu trabalho?

Sim! Para mim, ele é muito importante por sua clarividência, sua radicalidade e por seu sentido de amplificação.

$0 \mathrm{Sr}$. acha que a fotografia como linguagem ainda depende muito do discurso textual? Temos a semiologia, a semiótica, as teorias que buscam falar sobre fotografia, e penso que a prática ainda não atingiu uma certa autonomia...

Para mim, a fotografia é texto. Não há diferença entre fotografia e texto. A fotografia pode ser compreendida como texto. Texto que impõe algumas particularidades de leitura, mas que funciona da mesma maneira.

\section{Flusser cria uma relação entre texto e fotografia na própria estrutura...}

Há uma teoria que estabelece a independência entre a imagem e o texto, como se, dessa maneira, a imagem se tornasse uma presença, presença da própria realidade. Mas para mim não se trata de códigos, sistemas, que nos permitam o apreço da experiência da realidade, mas se trata de darmos conta da imagem como linguagem, portanto, como recurso ao relato, à narrativa.

0 Sr. pratica fotografia com frequência? É do tipo que fotografa o tempo inteiro...

Para mim a fotografia não é uma técnica ou procedimento, mas é uma cultura de visão que se sustenta sobre valores desenvolvidos numa cultura técnico-cientifica, portanto, valores como verdade, identidade, memória, fragmentação... há toda uma série de vetores que definem o paradigma fotográfico. Para mim, você utilizar uma câmera ou um laboratório é algo contingente e acessório, pois o importante, o verdadeiramente substancial para o fotográfico é este conjunto de valores. Mas estes conceitos podem ser colocados por outros procedimentos, podem ser colocados por meio do texto, do vídeo, da música... a fotografia deve desligar-se das raízes 
técnicas que a identificam. Por exemplo, gosto muito de dizer que um escritor como Borges era um fotógrafo, apesar de não ser alguém que se expressava pela fotografia. Mas seu universo era muito próximo do que é o universo da fotografia, de espelhos e ilusões, com toda uma erudição ao redor do ato de duplicar o mundo que, para Borges, era uma biblioteca, mas para mim, é uma fotografia.

Existe um pensar de modo fotográfico...

Exatamente. E que traduz o pensar moderno. A Idade Moderna é atravessada por essa cultura fotográfica. 